\title{
CO-PRODUCTION OF HYDROGEN AND ELECTRICITY USING \\ PRESSURIZED CIRCULATING FLUIDIZED BED GASIFICATION TECHNOLOGY
}

Final Report By:

Zhen Fan

Archie Robertson

Issued August 2006

Performed Under

U.S. Department of Energy

Cooperative Agreement No: DE-FC26-00NT40972

DEVELOPMENT OF PRESSURIZED CIRCULATING FLUIDIZED BED

PARTIAL GASIFICATION MODULE

Foster Wheeler Development Corporation

12 Peach Tree Hill Road

Livingston, New Jersey 07039 


\section{Disclaimer}

"This report was prepared as an account of work sponsored by an agency of the United States Government. Neither the United States Government nor any agency thereof, nor any of their employees, makes any warranty, express or implied, or assumes any legal liability or responsibility for the accuracy, completeness, or usefulness of any information, apparatus, product, or process disclosed, or represents that its use would not infringe upon privately owned rights. Reference herein to any specific commercial product, process, or service by trade name, trademark, manufacturer, or otherwise does not necessarily constitute or imply its endorsement by the United States Government or any agency thereof. The views and opinions of authors expressed herein do not necessarily state or reflect those of the United States Government or any agency thereof." 


\section{Acknowledgement}

This work was performed by Foster Wheeler Development Corporation under U.S. Department of Energy (DOE) Cooperative Agreement No. DE-FC26-00NT40972. Arun C. Bose was the DOE Contracting Officer's Technical Representative that guided the conduct of the work.

The Parsons Infrastructure and Technology Group assisted Foster Wheeler by providing engineering and economic analyses of the cases studied herein. Parsons provided this assistance via National Energy Technology Laboratory Contract No DE-AM26-04NT41817 (Subtask No 41817.305.61.11.051).

The Parsons' personnel and their subcontractors that participated in the study were:

Harvey Goldstein, Project Manager, Parsons Infrastructure and Technology Group Jay White, Performance Engineer, WorleyParsons

William McMahon Jr., Estimator and Economic Analyst, Econ Opportunities, Inc. 


\begin{abstract}
Foster Wheeler has completed work under a U.S. Department of Energy cooperative agreement to develop a gasification equipment module that can serve as a building block for a variety of advanced, coal-fueled plants. When linked with other equipment blocks also under development, studies have shown that Foster Wheeler's gasification module can enable an electric generating plant to operate with an efficiency exceeding 60 percent (coal higher heating value basis) while producing near zero emissions of traditional stack gas pollutants. The heart of the equipment module is a pressurized circulating fluidized bed (PCFB) that is used to gasify the coal; it can operate with either air or oxygen and produces a coal-derived syngas without the formation of corrosive slag or sticky ash that can reduce plant availabilities.

Rather than fuel a gas turbine for combined cycle power generation, the syngas can alternatively be processed to produce clean fuels and or chemicals. As a result, the study described herein was conducted to determine the performance and economics of using the syngas to produce hydrogen for sale to a nearby refinery in a hydrogen-electricity co-production plant setting. The plant is fueled with Pittsburgh No. 8 coal, produces 99.95 percent pure hydrogen at a rate of 260 tons per day and generates $255 \mathrm{MWe}$ of power for sale. Based on an electricity sell price of $\$ 45 / \mathrm{MWhr}$, the hydrogen has a 10-year levelized production cost of $\$ 6.75$ per million Btu; this price is competitive with hydrogen produced by steam methane reforming at a natural gas price of \$4/MMBtu. Hence, coal-fueled, PCFB gasifier-based plants appear to be a viable means for either high efficiency power generation or co-production of hydrogen and electricity.
\end{abstract}

This report describes the PCFB gasifier-based plant, presents its performance and economics, and compares it to other coal-based and natural gas based hydrogen production technologies. 


\section{Table of Contents}

$\underline{\text { Section }} \quad \underline{\text { Page }}$

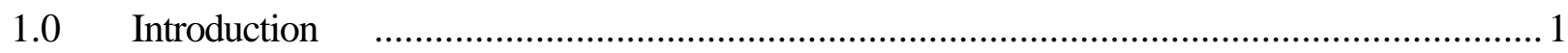

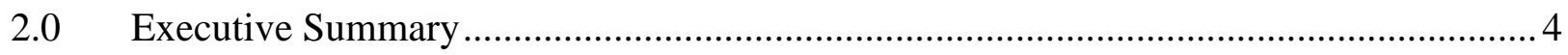

3.0 Experimental / Plant Design and Economic Bases ............................................... 7

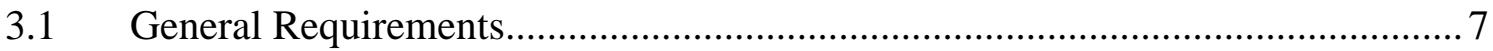

3.2 Plant Site Conditions .......................................................................... 8

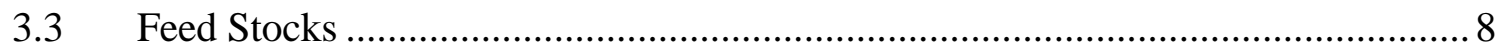

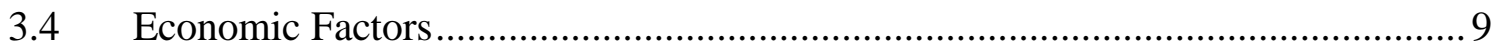

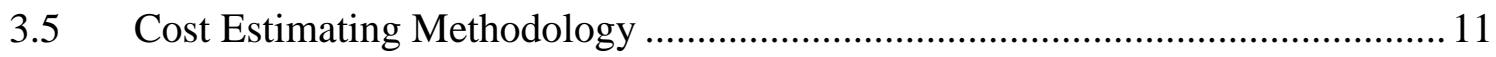

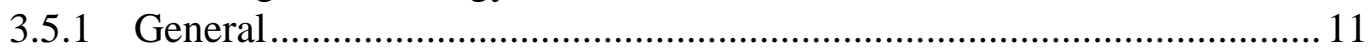

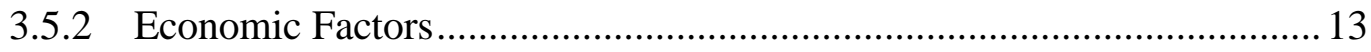

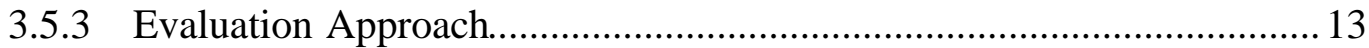

3.5.4 Capital Costs ........................................................................ 14

3.5.5 Bare Erected Costs......................................................................... 14

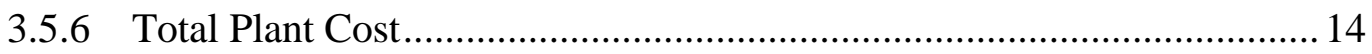

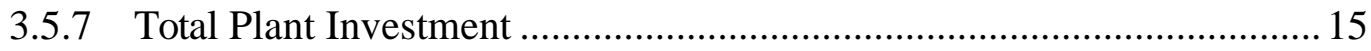

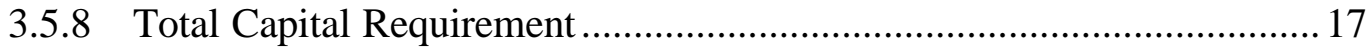

3.5.9 Capital Cost Estimate Exclusions ................................................... 17

3.5.10 Operating and Maintenance Costs .................................................... 18

3.5.11 Consumable Operating Costs.......................................................... 19

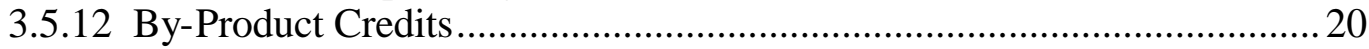

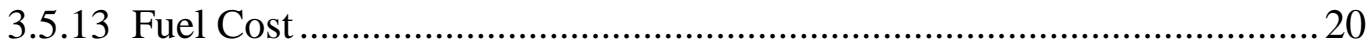

3.5.14 Total Production Cost ..................................................................... 20

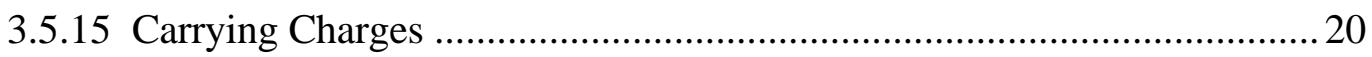

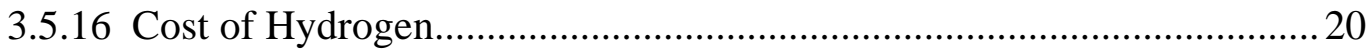

4.0 Entrained Flow Gasifier Based Co-Production Plant ...............................................22

4.1 Plant Overview, Performance, and Emissions ............................................. 22

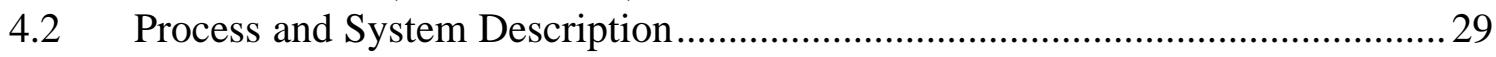

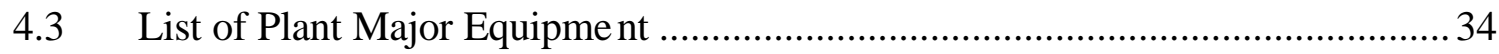

4.4 Plant Costs and Economic Analysis ........................................................ 34

5.0 PCFB Gasifier Based Co-Production Plant ............................................................. 41

$5.1 \quad$ Plant Overview, Performance, and Emissions ............................................ 41

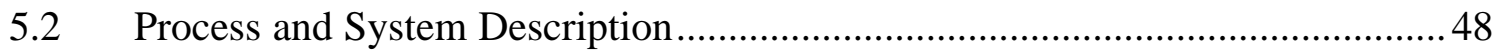

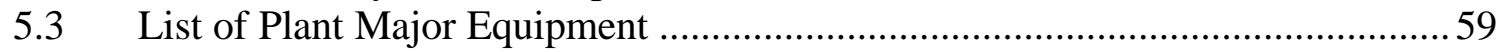

$5.4 \quad$ Plant Costs and Economic Analysis ........................................................59

6.0 Hydrogen Production by Steam Methane Reforming (SMR) .................................... 64

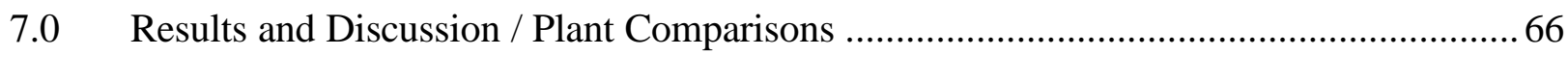




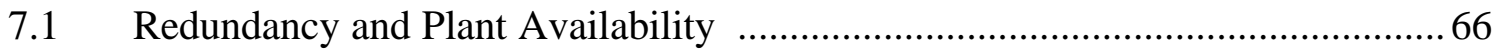

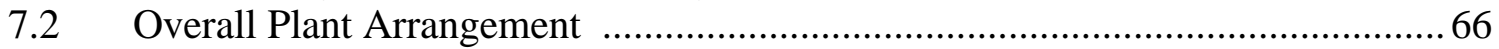

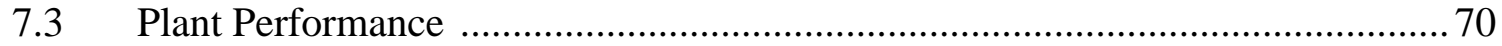

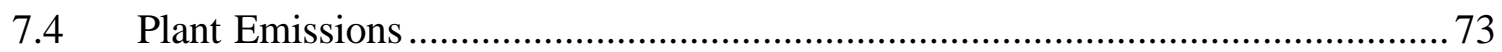

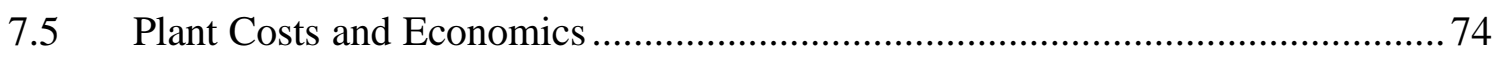

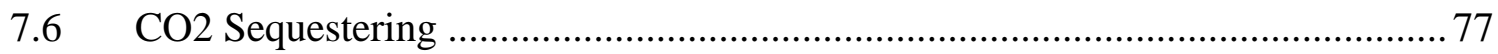

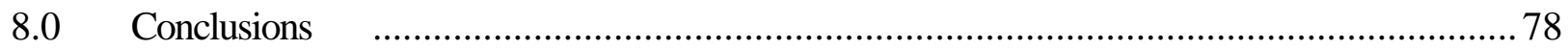

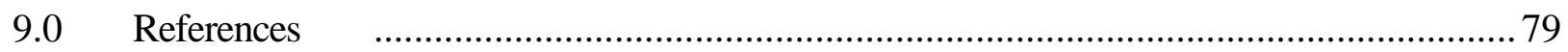

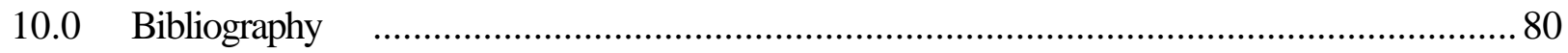

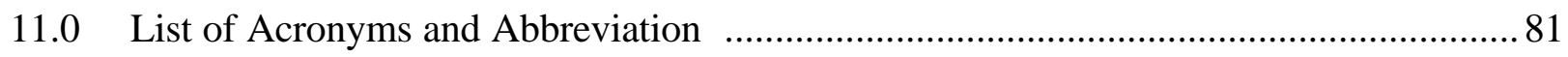

Appendix A E-Gas Entrained Flow Gasifier Co-Production Plant with Spare Gasifier ........ A1

A1. List of Major E-Gas Co-Production Plant Equipment by Account .................. A2

A2. Total Plant Cost Estimate..................................................................... A12

Appendix B E-Gas Entrained Flow Gasifier Co-Production Plant without Spare Gasifier.....B1

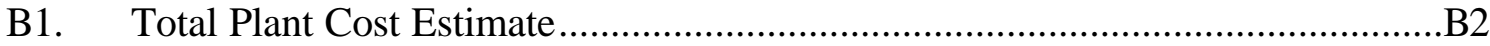

Appendix C Foster Wheeler PCFB Gasifier Co-Production Plant .................................... C1

C1. List of Major PCFB Co-Production Plant Equipment by Account .................... C2

C2. Total Plant Cost Estimate....................................................................... C11 


\section{List of Graphical Materials}

$\underline{\text { Figures }}$

$\underline{\text { Page }}$

1.1

PCFB Gasification Module for Advanced Energy Plants................................... 2

3.5.4.1

4.1 .1

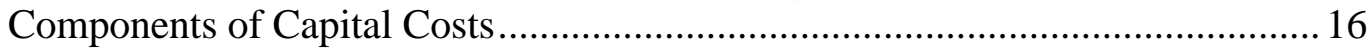

4.1.2

Entrained Flow Plant Process Block Diagram................................................2 23

4.1 .3

5.1 .1

5.1 .2

5.1 .3

5.2 .1

5.2 .2

5.2 .3

5.2 .4

5.4 .1

6.1

6.2

7.2 .1

Entrained Flow Plant Process Stream Locations ..............................................2 25

Entrained Flow Plant Process Stream Operating Conditions ............................ 26

PCFB Gasifier Plant Process Block Diagram ................................................... 42

PCFB Gasifier Plant Flow Stream Locations .................................................. 44

PCFB Gasifier Plant Flow Stream Operating Conditions ................................. 45

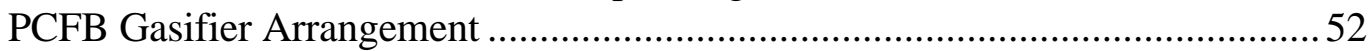

CFB Boiler Side View ............................................................................. 55

CFB Boiler Isometric View .........................................................................56

Spray Dryer Scrubber, Baghouse, ID Fan, and Stack Side View .......................57

Effect of Electricity Sell Price on PCFB Plant $\mathrm{H}_{2}$ Sell Price............................... 64

Natural Gas Steam Reforming Process Block Diagram ...................................65

Cost of Hydrogen Produced from Steam Methane Reforming ...........................65

Two Train IGCC Comb ined Cycle Plant Arrangement......................................6 69

$\underline{\text { Tables }}$

2.1

3.3.1

3.3 .2

3.4.1

3.4 .2

3.5.10.1

3.5.11.1

4.1.1

4.1.2

4.1.3

4.4 .1

4.4 .2

4.4 .3

4.4 .4

4.4 .5

4.4 .6

5.1 .1

5.1 .2

Summary Comparison of Co-Production Plant Performance \& Economics ......... 7

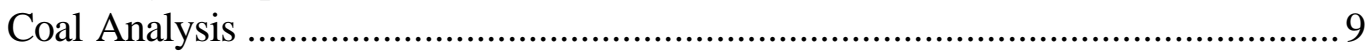

Limestone Composition .......................................................................... 9

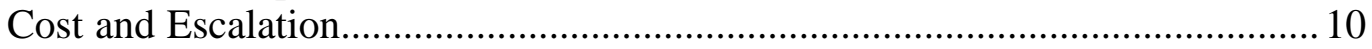

Estimating Criteria and Financial Assumptions ............................................. 11

Operating Labor for Co-Production Plants ................................................... 19

Consumable Unit Costs........................................................................... 20

E-Gas Entrained Flow Plant Performance Data............................................. 27

E-Gas Entrained Flow Plant Parasitic Power....................................................2 28

E-Gas Entrained Flow Plant Emissions ......................................................... 29

E-Gas Plant TPC in Thousands of Year 2005 Dollars (3 \& 2 Train Plants) ....... 35

E-Gas Plant Operating and Consumable Requirements ................................... 36

E-Gas Plant Operating and Consumables Costs ............................................. 37

E-Gas Plant Hydrogen Production Cost (3 Train Plant)................................... 38

E-Gas Plant Hydrogen Production Cost (2 Train Plant)................................... 39

E-Gas Plant Economic Summary (3 \& 2 Train Plants) .................................... 40

PCFB Gasifier Plant Performance Summary............................................. 46

PCFB Gasifier Plant Parasitic Power Losses ................................................. 47

5.1.3 PCFB Gasifier Plant Emissions ............................................................. 48

5.2.1 PCFB Gasifier Syngas Compositions ........................................................53

5.4.1 PCFB Plant TPC in Thousands of Year 2005 Dollars ......................................6 60

5.4.2 PCFB Plant Capital and Operating Requirements .......................................6 61

5.4.3 PCFB Plant Operating and Consumables Costs ............................................62 
PCFB Plant Hydrogen Production Cost..........................................................6 63 


\subsection{Introduction}

One of the objectives of the Energy R\&D Program of the US Department of Energy (DOE) is to develop the technologies that will be required by the advanced, coal fueled, energy plants of the $21^{\text {st }}$ century. Rather than develop a specific plant configuration, the program focuses on developing "enabling" technologies that can serve as building blocks through which a variety of advanced power generation and or clean fuels/chemical production plants can be built. When utilized for electrical power generation, those plants are to operate with efficiencies greater than 60 percent (coal higher heating value basis) while producing near zero emissions of traditional stack gas pollutants.

Foster Wheeler Development Corporation (FW) proposed the development of a gasification equipment module (see Figure 1.1) that can serve as a building block for a variety of advanced, coal-fueled, energy plants. Analyses conducted by FW and Nexant [1-1] and an independent analysis conducted by [1-2] both indicate the gasification module, together with other building blocks, can yield a power generating plant with an efficiency that exceeds the 60 percent goal. The heart of the gasification module is a pressurized circulating fluidized bed (PCFB) gasifier that does not attempt to consume the coal in a single step. To convert all the coal to syngas in a single step requires extremely high temperatures $\left(\sim 2500\right.$ to $\left.2800^{\circ} \mathrm{F}\right)$ that melt and vaporize the coal and drive coal ash contaminants into the syngas. These contaminants can foul and or corrode the gasifier and downstream equipment and the syngas must be cooled to near room temperature to enable a series of chemical processes to clean the syngas. FW's process operates at much lower temperatures that extend component life, minimize the release of ash contaminants, and allow the use of sulfur and alkali capturing adsorbents. As a result, sticky ash fouling conditions, molten slag corrosion conditions, and the need for room temperature chemical cleanup systems, all of which are typical of high temperature gasification, are eliminated.

By performing the gasification in a circulating fluidized bed (CFB), which consists of a riser section, a recycle cyclone, and a dipleg, coal particles are continuously circulated through the gasification zone; despite the reduced temperature, each succeeding pass increases the amount of coal carbon that is converted into syngas. Eventually the circulating coal particles reach a density and size that allow their escape from the unit; exiting as syngas entrained particulate matter, the escaping char particles are collected by a down stream barrier filter. As a result, the PCFB gasifier produces a coal char residue along with syngas. Depending upon the coal and operating conditions, carbon conversions can range from mid eighties for less reactive Eastern bituminous coals to mid nineties for more reactive Western subbituminous coals. The circulating bed also provides high fuel flexibility, facilitates scale up to large size plants, and can operate with oxygen to facilitate sequestration of stack gas carbon dioxide gases for a reduction in greenhouse gas emissions.

The char generated by the PCFB gasifier is not a waste stream, instead, it is an extremely essential ingredient in maximizing the plant efficiency. After collection, the char is transferred to a combustor where it becomes a source of high level heat for the plant's steam cycle. In a typical integrated gasification combined cycle (IGCC) plant the steam turbine operating temperatures (superheat and reheat) are limited by the energy content of the gas turbine exhaust. With the char heat release available to supplement this, steam turbine pressures and temperatures are no longer limited to $2400 \mathrm{psig}$ and $1000^{\circ} \mathrm{F}$ but instead can rise to ultra supercritical conditions and operate 


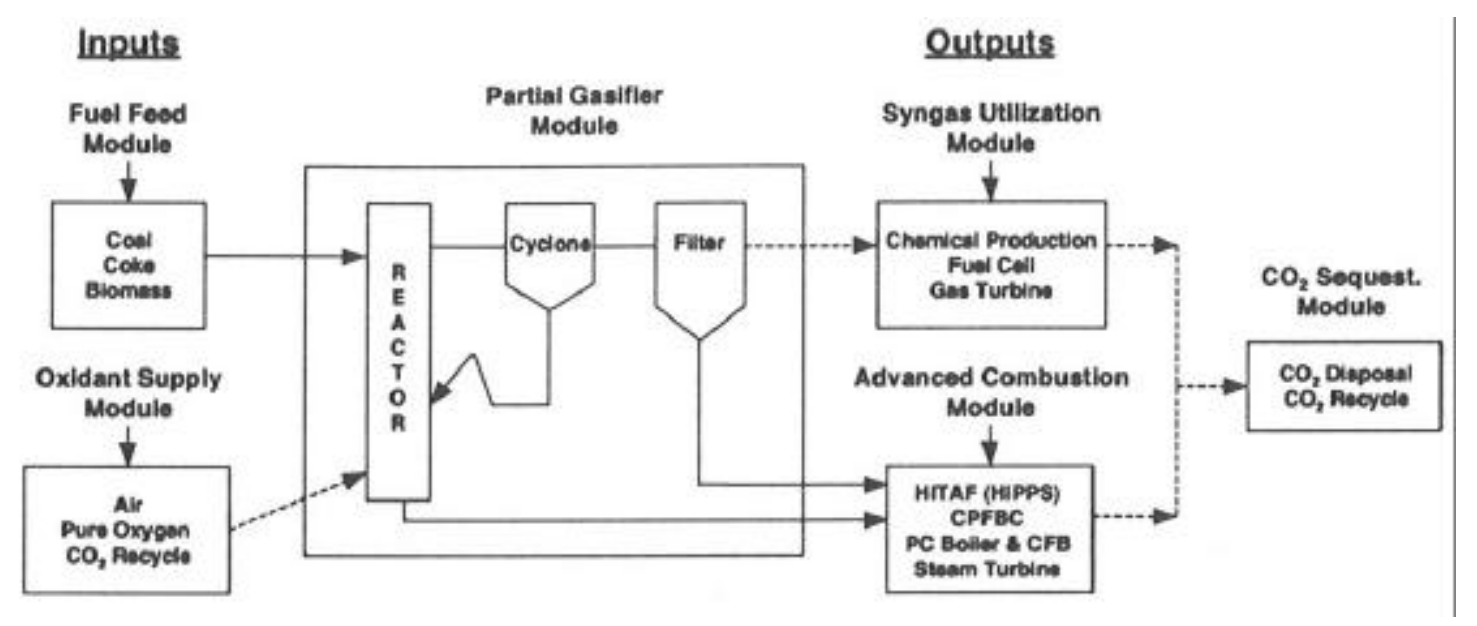

Figure 1.1 PCFB Gasification Module for Advanced Energy Plants

with a highly efficient regenerative feed water heating system. By having a char stream to combust, the steam cycle efficiency and the overall plant efficiency can be increased.

The gasification equipment module consists of the PCFB gasifier and a downstream, particulate removing barrier filter; if desired, a syngas cooler can be provided upstream of the filter to control its operating temperature. Coal, air, and steam are fed to the bottom of the PCFB riser and establish a relatively dense bed of coal/char in the bottom section. As these constituents react, a hot syngas is produced which conveys the solids residue vertically up through the reactor and into the recycle cyclone. Solids elutriated from the dense bed and contained in the syngas are collected in the cyclone and drain via a dipleg back to the dense bed at the bottom of the PCFB reactor. This recycle loop of hot solids acts as a thermal flywheel and promotes efficient solid-gas chemical reaction. As the solids continuously circulate through the gasifier, they reach a density and or size that eventually allow their escape from the recycle cyclone to the downstream filter. The filter collects this material for depressuring and transfer to the char combustor. To prevent any over size material from accumulating within the gasifier, solids are intermittently drained from the bottom of the bed, depressured, and also transferred to the char combustor.

Left untreated the particle bearing syngas will contain contaminants such as alkali vapors, hydrogen sulfide, ammonia, etc. at levels dependent on gasifier operating conditions and fuels. The downstream users of the syngas will dictate a tolerance level for each of these gas constituents. If hydrogen sulfide cannot be tolerated, lime based sorbents can be fed to the PCFB gasifier along with the coal to capture the sulfur as calcium sulfide. Depending upon sorbent feed rates and gas residence times, the hydrogen sulfide can be reduced to near equilibrium levels, which for high sulfur fuels (>3 percent sulfur), amounts to 95 to 98 percent sulfur capture. In addition to providing sulfur capture, lime based sorbents will catalytically enhance the cracking of any tar/oil vapors that may be present in the syngas.

If alkali vapors levels must be reduced, the syngas can be cooled to a level that condenses the alkali vapors on the particulate being removed by the barrier filter. Although this is a simple solution to an alkali problem, syngas cooling typically lowers the plant efficiency. When 
efficiency is to be maximized, the clean up can be done hot/without syngas cooling. Alkali levels can be brought to gas turbine acceptable levels by injecting finely ground getter material such as emathlite or bauxite into the syngas between the recycle cyclone and filter. The fine particulate that escapes the recycle cyclone together with the injected alkali getter material are carried into the barrier filter by the syngas. As the syngas flows through the porous filter elements, the particulate collect on the outside of the elements and forms a permeable dust cake that the syngas must pass through. The getter absorbs the alkali vapors as the syngas flows to the filter and passes through the filter dust cake. As the dust cake thickness increases, the filter pressure drop increases. Upon reaching a predetermined pressure drop, the dust cake is blown off the element by a back pulse of a clean, high-pressure gas such as nitrogen or recycled syngas injected into the clean side of the element. The dislodged dust cake falls to the bottom of the filter vessel and drains from the unit. If even higher sulfur capture efficiencies are desired, a second more reactive sorbent can be injected into the syngas for enhanced filter cake sulfur capture. Although the barrier filter is provided to reduce syngas particulate loadings to less than $1 \mathrm{ppm}$, it can also serve as a reactor in that its filter cake can be used for alkali vapor removal and sulfur capture. If costs are to be minimized, the filter can be preceded by a pre-cleaner cyclone that reduces the particulate loading entering the filter and allows a smaller unit to be utilized.

To support the development of PCFB gasification, pilot plant tests were conducted by FW at its John Blizard Research Center in Livingston, NJ, in the September 2001 through January 2002 time period; the tests determined gasification module performance characteristics when operating with a variety of fuels, e.g., one subbituminous coal, four bituminous coals, petroleum coke, and saw dust. The module consisted of a 7 inch ID PCFB gasifier together with a recycle cyclone, a syngas cooler, a pre-cleaner cyclone, and a barrier filter. The module operated successfully with all the fuels and a total of 22 test points were completed. The syngas and char yields, heating values, compositions, and carbon conversions observed in the pilot plant test program were found to meet and or exceed levels required by FW's Vision 21 electric power generating plant.

Rather than fuel power generation, the syngas could alternatively be processed to produce clean fuels and or chemicals. To identify the merits of such an arrangement, the performance and economics of using the gasification module/building block to simultaneously co-produce hydrogen and electricity has been studied in this report.

Working under DOE contracts, Parsons Infrastructure and Technology Group Inc. (Parsons) has conceptually designed and determined the performance and economics of several entrained flow type IGCC plants. These studies have included plants designed for electric power generation [1-3 ] as well as a plant designed primarily for the production of hydrogen [1-4 ]. To minimize the cost of the co-production plant study, it was decided to design the plant for the same hydrogen and electricity production rates of a co-production plant conceptually designed and cost estimated by Parson; this allowed reuse of much of the balance of plant design and costing work already performed by Parsons. To assure a consistent comparison of PCFB gasification versus entrained flow gasification technologies, Parsons was retained via a separate DOE contract to work with FW to determine and compare the performance and economics of both plants. The results of Parsons' efforts are presented in [1-5]. 
The plants, which have been conceptually designed to produce 261 tons of hydrogen per day and approximately 255 MWe of electricity, are described in detail in Sections 4 and 5; in Section 7 their performance and economics are compared to each other and to that of a natural gas steam reforming plant described in Section 6.

\subsection{Executive Summary}

FW has developed a coal gasification process that can serve as a building block for a variety of advanced energy plants. When utilized for electric power generation with other advanced components under development, those plants will operate with efficiencies greater than 60 percent (higher heating value basis) while producing near zero emissions of traditional stack gas pollutants. The heart of the equipment module is a pressurized circulating fluidized bed (PCFB) that is used to gasify the coal; it can operate with either air or oxygen and produces a coal-derived syngas without the formation of corrosive slag or sticky ash that can reduce plant availabilities.

Rather than fuel a gas turbine for combined cycle power generation, the syngas can alternatively be processed to produce clean fuels and or chemicals. As a result, the study described herein was conducted to determine the performance and economics of using the syngas to produce hydrogen for sale to a nearby refinery in a hydrogen-electricity co-production plant setting.

To minimize the cost of the co-production plant study, it was decided to design the PCFB based plant for the same hydrogen and electricity production rates of a co-production plant conceptually designed and cost estimated by the Parsons Infrastructure and Technology Group Inc. (Parsons); this allowed reuse of much of the balance of plant design and costing work already performed by Parsons. To assure a consistent comparison of PCFB gasification versus entrained flow gasification technologies, Parsons was retained, via a separate DOE contract, to work with FW to determine and compare the performance and economics of both plants.

The plants were conceptually designed to produce 261 tons of hydrogen per day and approximately 255 MWe of electricity. The plants were fueled with Pittsburgh No 8 coal and used pressure swing absorption (PSA) technology to produce 99.95 percent purity hydrogen. The hydrogen was produced for sale to a near by refinery at a pressure of approximately 355 psig, whereas, the electricity was sold to the grid.

The entrained flow gasifier plant uses two 50 percent capacity, oxygen blown, gasifier equipment trains to meet its syngas needs. The first operating train produces syngas for hydrogen production, whereas, the second train produces an equal amount of syngas for power generation. Although the trains operate in parallel at identical conditions, their gases are kept separate to simplify control and operating stability (assures an upset/problem in one leg of the plant will not disrupt the other). The operating reliabilities of the single train, coal fueled, IGCC demonstration plants that were built in the 1990s have been well below 90 percent. At the Year 2005 Gasification Technologies Conference two IGCC developers (ConocoPhillips, owner of the E-Gas Process, and GE Energy, owner of the ChevronTexaco Process) recommended that their two train IGCC plants be provided with a third or spare train of gasifier equipment to achieve 90 percent plant availability [2-1], [2-2]. Consistent with this, the E-Gas based co-production plant has been provided with a third/spare 50 percent train. The spare train will be brought on-line for either hydrogen or power production when one of the other two trains is shut-down for maintenance; to allow for future 
technology improvements, however, plant economics are presented both with and without the spare train.

Each gasifier equipment train consists of a coal-water slurry tank, a slurry pump, a slurry heater, a two stage entrained flow gasifier as exemplified by the E-Gas ${ }^{\mathrm{TM}}$ gasifier at the Clean Coal Technology Wabash River Repowering Project, a slag rejection system, a fire-tube boiler/syngas cooler, a cyclone, a candle filter, a water scrubber, and a fines return system. The syngas generated by the gasifier is cooled to $690^{\circ} \mathrm{F}$ by the fire-tube boiler to allow removal of gas entrained particulate by the cyclone and filter. After cooling, particulate removal, and water scrubbing, the syngas from the first train undergoes water gas shifting, acid gas removal, and pressure swing absorption (PSA) to produce 99.95 percent pure hydrogen at a rate of 261 tpd at 355 psig for sale to the nearby refinery. The $\sim 20$ psia low Btu purge gas/vent gas from the PSA is fired in a boiler to produce steam for the process and to drive a nominal $50 \mathrm{MWe}$ steam turbine. The syngas from the second train undergoes carbonyl sulfide (COS) hydrolysis, acid gas removal, reheating, and humidification; this gas then fuels a combined cycle plant incorporating a 197 MWe General Electric 7FA gas turbine and a nominal 100 MWe steam turbine; the electric power from both trains is sold to the grid to provide a revenue stream that reduces the hydrogen sell price.

The PCFB co-production plant utilizes a single, oxygen blown PCFB gasifier together with a single, atmospheric pressure CFB boiler to meet the plant hydrogen and power generation needs. Since the PCFB gasifier operates at a relatively low temperature that is below the coal ash fusion temperature, its availability is expected to be typical of CFB boilers, e.g., ( $~ 95$ percent per Section 7.1) and a spare train of gasifier equipment is not required. To assure a consistent comparison of the two plants, the PCFB gasifier operates with the same coal-water slurry and oxygen feeds as the entrained flow plant and its syngas is cooled by a fire-tube type boiler to $650^{\circ} \mathrm{F}$ to allow particulate removal by a cyclone and candle filter. Thereafter water gas shifting and PSA technology are used to produce 99.95 percent pure hydrogen at a rate of 261 tpd at 355 psig for sale to the refinery. The vent gas from the PSA and the char from the gasifier, the latter after depressuring, are fired along with crushed coal and limestone in the CFB boiler. The CFB boiler package, which includes a sulfur dioxide $\left(\mathrm{SO}_{2}\right)$ polishing scrubber, produces steam for process use and drives a nominal $308 \mathrm{MWe}$ steam turbine. The steam turbine power is sold to the grid to provide a revenue stream that reduces the hydrogen sell price. In the event the gasification leg of the plant should be out of service, the CFB boiler can be operated totally on coal to maintain its full load revenue stream.

The economics of both plants have been analyzed using a consistent set of assumptions, i.e., Pittsburgh No. 8 coal price of \$1.61/MMBtu, an electricity sell price of \$45/MWhr, etc., and Table 2.1 summarizes the results of the study. The PCFB gasifier based plant operates with an effective thermal efficiency of 53.0 percent (coal higher heating value basis), a total plant cost in year 2005 dollars of $\$ 625.4$ million, and produces hydrogen at a 10 year levelized cost of \$6.75/MMBtu. The levelized cost accounts for all capital, consumables, fuel, operating and maintenance, and interest costs and includes a 12 percent return on equity. Compared with the entrained flow plant, the PFB gasifier plant efficiency is 5.4 percentage points higher, its total plant costs 7.8 percent lower, and its levelized hydrogen cost 4.4 percent lower. 
In the PCFB gasifier based plant, the stack gases originate from the CFB boiler system and the latter becomes the emission control system of the plant. The emissions shown in Table 2.1 for the PCFB gasifier based plant are based on pound per million Btu emission rates measured in the Jacksonville Electric Authority 300 MWe CFB Boiler Demonstration Project with its CFB boiler operating with Pittsburgh No 8 coal, the fuel of this study. The entrained flow gasifier plant emissions are also shown in Table 2.1; they are based on rates observed at the Wabash IGCC Demonstration Plant but modified to incorporate recycle of Claus Plant tail gas back to the gasifier and gas turbine nitrogen injection. These features have been incorporated to improve the plant's sulfur capture efficiency and reduce its gas turbine oxides of nitrogen (NOx) emissions. As shown in Table 2.1, the NOx and particulate emissions of the two plants are comparable with the most significant differences occurring in $\mathrm{SO}_{2}$ and carbon monoxide (CO) emissions. Recycling the Claus Plant tail gas back to the gasifier is expected to increase the plant sulfur capture efficiency from $~ 98$ to 99.5 percent. With the CFB boiler system operating at the Jacksonville 98.5 percent sulfur capture efficiency, the entrained flow gasifier plant $\left(\mathrm{SO}_{2}\right)$ emission is projected to be about $1 / 3$ of that of the PCFB gasifier plant. In contrast, the CO emission rate of the PCFB gasifier based plant is about $1 / 5$ of that of the entrained flow gasifier plant.

Hydrogen is typically produced by steam methane reforming and its production costs are highly sensitive to the price of its natural gas feedstock. At a levelized cost of \$6.75/MMBtu, hydrogen produced by the PCFG gasifier plant will be competitive with steam methane produced hydrogen at a natural gas price of approximately $\$ 4 / \mathrm{MMBtu}$. With natural gas spot prices well above these values, the future prospects of PCFB gasifier produced hydrogen appear favorable.

The efficiencies and hydrogen costs of the above coal and natural gas based plants are exclusive of carbon dioxide $\left(\mathrm{CO}_{2}\right)$ removal for sequestration. All of these plants, however, can incorporate $\mathrm{CO}_{2}$ removal and, hopefully, the effect of its capture on the PCFB gasifier based plant performance and economics will be the subject of a later study.

Previous studies [1-1] [1-2] have shown that PCFB gasifier based plants can meet the Vision 21 60 percent efficiency goal for advanced power generating plants. This study has shown that the PCFB gasifier based co-production plant can produce hydrogen at a cost competitive with that of steam methane reforming. The amount of syngas and char produced by the PCFB gasifier can be tailored to fit the production objectives of the overall plant, e.g., power generation and/or hydrogen production. Although not yet studied, it is believed it may also be a viable means for producing liquid fuels and chemicals from coal. Hence, the PCFB gasifier is a product-flexible, robust building block by which a wide variety of plants can be built - be they Vision 21 plants of the future or a high efficiency combined cycle/gas turbine-steam turbine plant of today 
Table 2-1 Summary Comparison of Co-Production Plant Performance and Economics

$\begin{array}{lcc}\text { Type of Gasifier } & \text { Entrained Flow } & \text { PCFB } \\ \text { Plant Effective Thermal Efficiency*, \% (HHV) } & 47.6 & 53.0 \\ \text { H2 Production Rate, lb/hr } & 21,703 & 21,753 \\ \text { Net Power Output, MWe } & 251.9 & 255.5 \\ \text { Gross Power, MWe } & & \\ \text { 7 FA Gas Turbine } & 197.0 & \\ \text { Steam Turbine } & 149.0 & 307.7 \\ \text { Parasitic Power, MWe } & 94.1 & 52.2 \\ \text { Plant Sulfur Capture Efficiency, \% } & 99.5 & 98.5 \\ \text { Stack Emissions, Ib/hr } & & \\ \text { SO2 } & 107 & 289 \\ \text { NOx } & 194 & 197 \\ \text { CO } & 297 & 45 \\ \text { Particulate } & 8 & 24 \\ \text { Total Plant Cost, millions of Year 2005 Dollars } & 678.5^{* *} & 625.4 \\ \text { 10 Year Levelized H2 Production Cost, \$MMBtu } & 7.06 & 6.75\end{array}$

*Power at 3,413 Btu/hr/KWe and Hydrogen at $61,095 \mathrm{Btu} / \mathrm{lb}$

${ }^{* *} 647.8$ with spare gasification train eliminated

\subsection{Experimental/Plant Design and Economic Bases}

\subsection{General Requirements}

The PCFB gasifier based and the entrained flow gasifier based co-production plants were each designed to produce approximately 261 tpd ( $\sim 4$ MMSCF) of 99.95 percent purity hydrogen at 355 psig while simultaneously generating $\sim 255$ MWe of electric power. To assure a consistent comparison of the two technologies, both plant were designed to operate with:
a.) Pittsburgh No 8 coal
b.) coal-water slurry feed to gasifier(s)
c.) oxygen blown gasifier(s)
d.) 95 percent pure oxygen supplied by conventional cryogenic air separation units (ASU)s
e.) syngas cooling to $\sim 650 \mathrm{~F}$ via fire-tube boiler(s)
f.) syngas particulate removal at $\sim 650 \mathrm{~F}$ via a cyclone and candle filter
g.) water gas shifting via sulfur tolerant catalysts for a $\sim 91$ percent overall $\mathrm{CO}$ conversion efficiency at a steam to $\mathrm{CO}$ molar ratio of 1.75


h.) hydrogen separation via conventional PSA technology yielding 99.95 percent purity

i.) steam condenser back pressure of $1.0 \mathrm{psia}$

\subsection{Plant Site Conditions}

The plant site is assumed to be in the Ohio River Valley of southwestern Pennsylvania/eastern Ohio with the following characteristics:

Location

Topography

Elevation

Seismic Zone

Air Temperature

Relative Humidity

Transportation

Water

Ash Disposal
Middle Town USA

Level

500 feet (152.4 meters)

1

$59^{\circ} \mathrm{F}\left(15^{\circ} \mathrm{C}\right)$

60 Percent

Rail Access

Municipal

Off Site

\subsection{Feedstocks}

The plants have been designed to operate with 2.9 percent sulfur Pittsburgh No 8 coal and, if desired, limestone. Analyses of these feedstocks are given in Tables 3.3.1 and 3.3.2. 


$\begin{array}{lr}\text { Type/Name } & \text { Bitumino } \\ \text { As Received HHV, Btu/lb } & 12,450 \\ & \\ \text { Proximate Analysis, wt \% } & 6.00 \\ \text { Moisture } & 35.91 \\ \text { Volatile Matter } & 9.94 \\ \text { Ash } & 48.15 \\ \text { Fixed Carbon } & \\ & \\ \text { Ultimate Analysis, wt \% } & 69.36 \\ \text { Carbon } & 5.18 \\ \text { Hydrogen } & 1.22 \\ \text { Nitrogen } & 2.89 \\ \text { Sulfur } & 9.94 \\ \text { Ash } & 11.41 \\ \text { Oxygen } & \end{array}$

Table 3.3.2 Limestone Composition (wt \%)

$\begin{array}{lc}\text { Calcium Carbonate } & 92.7 \\ \text { Magnesium Carbonate } & 3.7 \\ \text { Inerts } & 3.6\end{array}$

\subsection{Economic Factors}

The cost and economic assumptions used in this study are given in Tables 3.4.1.and 3.4.2. 
Table 3.4.1 Cost and Escalation

Feed Costs

Coal, \$/MMBtu

Limestone, $\$$ ton

Water, $\$$ MMgal/day

Water Treatment Chemicals, \$/lb

Liquid Effluent Chemicals, \$/lb

Amine Acid Gas Removal Solvent, \$/lb

Ammonia, \$/lb

Catalyst Costs

Carbonyl Sulfide, $\$ / \mathrm{ft} 3$

First High Temperature Shifter, \$/ft3

Second High Temperature Shifter, \$/ft3

Low Temperature Shifter, \$/ft3

Claus Furnace Reactor \# 1, \$/ft3

Claus Furnace Reactor \# 2, \$/ft3

Hydrogenation, \$/ft3

Waste Disposal Costs

Ash/ Slag Disposal, \$/ton

By-Product Sell Price

Sulfur, \$/ton

Electricity, $\$ / \mathrm{MWhr}$

Other Costs

Plant Operating Labor, $\$ / \mathrm{hr}$

Plant Land, \$/acre

Year 2005
28.00

1.61

18.00

815.00

0.20

0.15

1.09

0.22

575.00

450.00

450.00

450.00

325.00

325.00

290.00

12.00

75.00

45.00

2500.00
0.10\% Inflation (2005-2025)

$2.50 \%$ Inflation (2005-2025)

$2.50 \%$ Inflation (2005-2025)

$2.50 \%$ Inflation (2005-2025)

$2.50 \%$ Inflation (2005-2025)

$2.50 \%$ Inflation (2005-2025)

$2.50 \%$ Inflation (2005-2025)

$2.50 \%$ Inflation (2005-2025)

$2.50 \%$ Inflation (2005-2025)

$2.50 \%$ Inflation (2005-2025)

$2.50 \%$ Inflation (2005-2025)

$2.50 \%$ Inflation (2005-2025)

$2.50 \%$ Inflation (2005-2025)

$2.50 \%$ Inflation (2005-2025)

$2.50 \%$ Inflation (2005-2025)

$2.50 \%$ Inflation (2005-2025)

$2.50 \%$ Inflation (2005-2025)

$2.50 \%$ Inflation (2005-2025)

$2.50 \%$ Inflation (2005-2025) 
for either power generating gas turbines [1-3] or for water gas shifting and pressure swing absorption (PSA) systems for hydrogen production [1-4].

In this study, plants incorporating E-Gas and PCFB gasification technologies are being evaluated/compared to determine their performance and economics for co-producing hydrogen and electricity. The first plant utilizes three 50 percent capacity E-Gas gasifiers. The first gasifier produces syngas for PSA based hydrogen production, the second gasifier produces syngas for gas turbine power generation, and the third gasifier is a spare that is brought on line when one of the other two gasifiers is shut down for repairs/maintenance. Although present experience indicates the spare gasifier is needed to achieve 90 percent plant availability, plant economics have been determined both with and without the spare to allow for future technology advances. Mass and energy balances were prepared by Parsons for the E-Gas based co-production plant and used to establish its equipment sizes and arrangements. Since the plant components were similar to those of the prior studies, Parsons used the prior study values to establish co-production plant equipment costs; adjustments were made, however, for differences in flow rates and the costs involved were escalated to year 2005 values using published engineering and construction indices. Since E-Gas technology has been successfully demonstrated at a 250 MWe scale at Wabash, no process contingencies were applied to the E-Gas equipment trains.

The second co-production plant, which is based on FW's circulating fluidized bed technologies, also utilizes two trains of operating equipment. The first equipment train is similar to the E-Gas based plant in that it utilizes a coal-water slurry fed, oxygen blown gasifier to produce a coalderived syngas for water gas shifting and PSA based hydrogen production. Unlike the E-Gas based plant, however, the FW plant utilizes a single PCFB to gasify its coal and the second train of equipment utilizes a CFB boiler to combust a mixture of coal, gasifier char, and PSA vent gas to produce steam for process use and electric power generation.

To permit a consistent comparison of the two technologies, the FW plant has been designed to coproduce the same amount of hydrogen and electric power as the E-Gas based plant; in addition, its gasifier has been designed to operate with similar support systems e.g. the FW plant utilizes the same coal-water slurry feed, cryogenic oxygen supply, fire-tube boiler cooling, syngas particulate removal (candle filter and pre-cleaner cyclone), high and low temperature water gas shifters, and PSA systems used by the E-Gas plant. The FW plant syngas flow rate is slightly less than ( $\sim 10$ per cent ) that of the E-Gas plant and, with the plants incorporating similar equipment systems and outputs, the cost of the FW plant was derived, for the most part, from the E-Gas co-production plant cost estimate. Where necessary, however, Parsons made adjustments for differences in flow rates and the deletions or additions of some equipment. The major equipment changes, which were priced by $\mathrm{FW}$, included:

1.) In the first equipment train the E-Gas plant gasifier, fire-tube boiler, and char recycle systems were replaced by the cost of FW's comparable systems and unneeded equipment was deleted i.e. water scrubber, acid gas removal, hydrogen sulfide gas concentrator, Claus plant, tail gas recycle systems, etc.

2.) In the second or power producing equipment train, which, in the case of the E-Gas plant, extends from the slurry and oxygen feed through the gas turbine, HRSG, and stack, the 
equipment was replaced by a CFB boiler system, which extends from coal and air supply through the stack.

FW has built several atmospheric pressure CFB gasifiers (largest has a $70 \mathrm{MWt}$ output [3-2]) and one PCFB gasifier; the latter operated at 360 psig and was provided for the world's first biomass fueled IGCC plant [3-3]. Since it is significantly smaller in size than that required by the coproduction plant (20 inch ID versus 60 inch ID), the FW plant cost estimate includes a 10 percent process contingency in the PCFB gasifier and syngas fire-tube boiler cost accounts; in addition, a 3 percent process contingency was applied to its coal-water slurry preparation and feeding account.

The costs of the E-Gas and FW based co-production plants are presented in Sections 4.4 and 5.4 respectively and each is broken down into 14 accounts to permit a detailed comparison of their costs. Since the costs, excepting those provided by FW, originate from prior studies and involve up to six years of escalation, they are best used for relative comparison purposes rather than a prediction of absolute plant costs.

\subsubsection{Economic Factors}

The costs and economics of the two co-production plants are based on the economic factors listed in Tables 3.4.1 and 3.4.2.

\subsubsection{Evaluation Approach}

The general estimate basis and assumptions are identified below:

- Total plant costs are expressed in January 2005 dollars.

- The estimate represents a mature technology plant, or "nth plant" (i.e., it does not include costs associated with a first-of-a-kind plant).

- The estimate represents a complete plant facility.

- The estimate boundary limit is defined as the total plant facility within the "fence line"; it begins at the rail road tracks entering the plant and terminates at the piping that begins to transport hydrogen to the adjacent refinery and the high side of the main power transformers.

- Site location is within the Ohio River Valley, southwestern Pennsylvania/eastern Ohio, but not specifically sited within the region.

- Terms used in connection with the estimate are consistent with the EPRI Technical Assessment Guidelines (TAG) [3-4].

- Costs are grouped according to a process/system-oriented code of accounts; all reasonably allocable components of a system or process are included in the specific system account in contrast to a facility, area, or commodity account structure. 
- Design engineering services, including construction management and contingencies are expressed as a percentage of equipment costs delivered to the job site.

- The fuel cost was developed on the basis of a straightforward calculation involving the plant size, plant heat rate, coal higher heating value, coal unit cost, plant annual operating hours, and a levelizing factor.

- The operating and maintenance expenses and consumables costs were developed on a quantitative basis.

- The operating cost is determined on the basis of the number of operators required.

- The maintenance cost is evaluated on the basis of relationships of maintenance cost to initial capital cost.

- The cost of consumables is determined on the basis of individual rates of consumption, the unit cost of each consumable, and the plant annual operating hours.

Each of these expenses and costs is determined on a first-year basis and levelized at the 10-year life of the plant through application of a levelizing factor to determine the value that forms a part of the hydrogen production cost.

\subsubsection{Capital Costs}

The capital cost, specifically referred to as total capital requirement (TCR) for the mature coproduction plant, was estimated using the EPRI methodology identified in Figure 3.5.4.1. The major components of TCR consist of bare erected cost, total plant cost (TPC), total plant investment (TPI), and owner's costs.

The capital cost was determined through the process of estimating the cost of major equipment items, components, and bulk quantities identified. A Code of Accounts was developed to provide the required structure for the estimate. The Code facilitates the consistent allocation of individual costs and is similar to that used by Parsons in prior studies. The Code facilitates recognition of estimated battery limits and the scope included in each account.

\subsubsection{Bare Erected Cost}

The bare erected cost level of the estimate, also referred to as the sum of process capital and general facilities capital, consists of the cost of factory equipment, field materials and supplies, direct labor, indirect field labor, and indirect construction costs. FW provided Parsons the cost of the PCFB gasifier and CFB boiler subsystems delivered to the job site. Parsons determined overall plant costs and economics.

\subsubsection{Total Plant Cost (TPC)}

The TPC level of the estimate consists of the bare erected cost plus engineering and contingencies. Engineering costs represent the cost of architect/engineer services for design/drafting and project construction management services and were set at 8 percent of the bare erected cost on an 
individual account basis. The cost for engineering services provided by the equipment manufacturers and vendors is included directly in the equipment costs.

Allowances for process and project contingencies are also part of TPC. Based on past experience and depending upon the state of development of the technology involved, Parsons assigned process and project contingencies on an account by account basis.

\subsubsection{Total Plant Investment (TPI)}

The TPI at date of start-up includes escalation of construction costs and allowance for funds used during construction (AFUDC), formerly called interest during construction, over the construction period. TPI is computed from the TPC, which is expressed on an "overnight" or instantaneous construction basis and a value of 5 percent applied to TPC was assumed for AFUDC. 


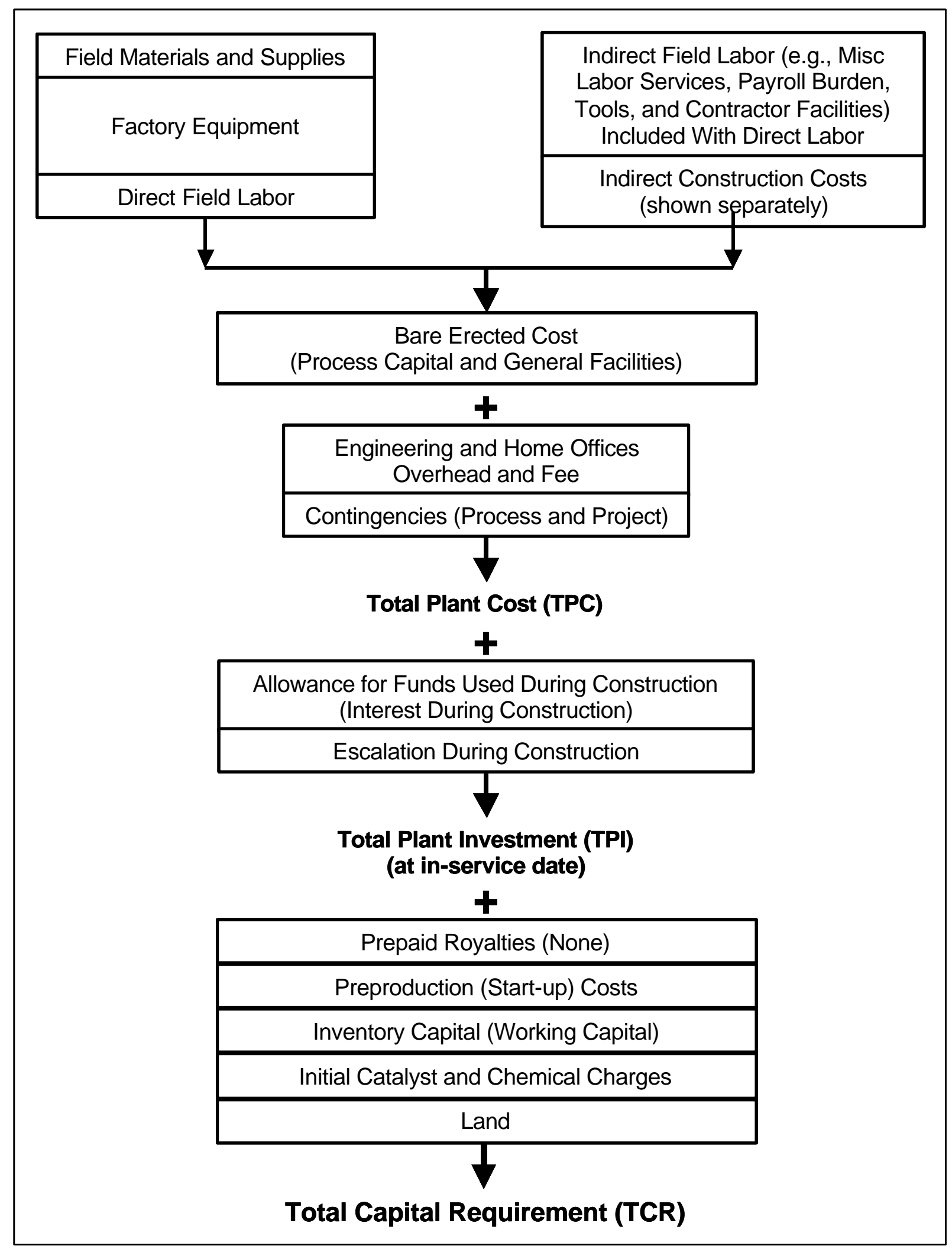

Figure 3.5.4.1 Components of Capital Cost 


\subsubsection{Total Capital Requirement (TCR)}

The TCR includes all capital necessary to complete the entire project. TCR consists of TPI, prepaid royalties, pre-production (or start-up) costs, inventory capital, initial chemical and catalyst charge, and land cost:

- Royalty costs have been assumed to be zero.

- Pre-production Costs are intended to cover operator training, equipment checkout, major changes in plant equipment, extra maintenance, and inefficient use of fuel and other materials during plant start-up. They are estimated as follows:

- 1 month of fixed operating costs - operating and maintenance labor, administrative and support labor, and maintenance materials.

- 1 month of variable operating costs at full capacity (excluding fuel) - includes chemicals, water, and other consumables and waste disposal charges.

- 25 percent of full capacity fuel cost for 1 month - covers inefficient operation that occurs during the start-up period.

- 2 percent of TPI - covers expected changes and modifications to equipment that will be needed to bring the plant up to full capacity.

- Inventory capital is the value of inventories of fuel, other consumables, and by-products, which are capitalized and included in the inventory capital account. The inventory capital is estimated as follows:

- Fuel inventory is based on full-capacity operation for 15 days.

- Inventory of other consumables (excluding water) is normally based on full-capacity operation for the same number of days as specified for the fuel.

- $\quad 1 / 2$ percent of the TPC equipment cost is included for spare parts.

- Initial catalyst and chemical charge covers the initial cost of any catalyst or chemicals that are contained in the process equipment (but not in storage, which is covered in inventory capital). No value is shown because costs are assumed to have been included in the component equipment capital cost.

- $\quad$ Land cost is based on 100 acres of land at $\$ 2,500$ per acre.

\subsubsection{Capital Cost Estimate Exclusions}

Although the estimate is intended to represent a complete plant, there remain several qualifications/exclusions as follows:

- Sales tax is not included (considered to be exempt).

- On-site fuel transportation equipment is not included (i.e., yard locomotive, bulldozers, etc.).

- Allowances for unusual site conditions, such as piling, extensive site access, excessive dewatering, extensive inclement weather, are not included.

- Switchyard (transmission plant) is not included. The cost scope terminates at the high side of the main power transformer.

- Ash disposal facility is excluded; only 3-day ash/slag storage silos have been provided (the ash disposal cost is accounted for in the ash disposal charge as part of consumables costs).

- Royalties. 


\subsubsection{Operating and Maintenance (O\&M) Costs}

The costs and expenses associated with operating and maintaining the plant include:

- Operating labor

- Maintenance

- Material

- Labor

- Administrative and support labor

The cost of operating labor was estimated from the number of operating jobs (OJ) needed to operate the plant (on an average-per-shift basis) and their average job labor rates. In the absence of quantitative data, both plants were assumed to require the same operating labor hours and, hence, incur the same operating labor cost. Table 3.5.10.1 identifies the labor classifications, number of personnel, and rates that were applied to both plants.

Since the development of the maintenance labor and maintenance material costs are interrelated, their cost bases are discussed together. Annual maintenance costs were estimated per TAG methodology as a percentage of the installed capital cost. Maintenance labor and material costs were estimated to be 2.35 percent of TPC for the FW plant and, because of the need for a third/spare gasifier train, 2.75 percent for the E-Gas plant. These costs were split 40 percent for materials and 60 percent for labor, whereas, administrative costs were set at 45.2 percent of operating labor costs.

The operating labor, maintenance material and labor, and other labor-related costs are combined to give a total operating and maintenance cost which is then divided into two components: 90 percent for fixed O\&M, which is independent of operation, and 10 percent for variable O\&M, which is proportional to operation. The first-year costs in January 2005 dollars and a 90 percent capacity factor assume normal operation and do not include the initial start-up costs, which are computed separately. A 10-year levelizing factor is applied to the first-year costs and expenses to arrive at appropriate values that contribute to the cost of electricity and hydrogen.

The other operating costs, consumables and fuel, are determined on a daily 100 percent operating capacity basis and adjusted to an annual plant operation basis, equivalent to operating at 100 percent load for 90 percent of the year (plant capacity factor).

The development of the actual values was performed on a Parsons model that is consistent with TAG. 
Table 3.5.10.1 Operating Labor for Co-Production Plants

\begin{tabular}{|l|c|}
\hline Operating Labor Rate(base) & $\$ 28.00$ per hour \\
\hline Operating Labor Burden & $35 \%$ of base \\
\hline Labor Overhead Charge Rate & $30 \%$ of base \\
\hline Operating Labor Hours per Year & 1,944 \\
\hline Administrative \& Support Labor & $45.15 \%$ of Operating Labor \\
\hline \multicolumn{2}{|c|}{} \\
\hline Operating Labor Requirements (OJ) & -4 Shifts Required \\
\hline Category & Number/Shift \\
\hline Skilled Operator & 3 \\
\hline Operator & 18 \\
\hline Foreman & 3 \\
\hline Lab Techs, etc Total OJs & 2 \\
\hline \multicolumn{2}{|c|}{26} \\
\hline
\end{tabular}

\subsubsection{Consumable Operating Costs}

Costs included in this category are:

- Consumables

- By-product credit (if applicable)

- Fuel cost

Feedstock and disposal costs are those consumable expenses associated with normal plant operation. Consumable operating costs are developed on a first-year basis and subsequently levelized over a 10-year period. The consumables category consists of water, chemicals, other consumables, and waste disposal.

The "water" component pertains to the acquisition charge for the water required for the plant steam cycle, cooling towers, scrubbers, miscellaneous services, and ash pug mills. The "chemicals" component includes the cost of limestone, catalysts, boiler water treatment, and ammonia.

The "other consumables" component consists of fuel oil and gases. The fuel oil quantity accounts for start-up heaters and miscellaneous users plus fuel for the auxiliary boiler; with the plants being base load units, these costs were assumed small and ignored.

The "waste disposal" component pertains to the cost allowance for off-site disposal of plant solid wastes. Although the ash from the CFB boiler can potentially be used for road construction, structural fill, agricultural fertilizing, etc., the economics of such uses would be highly site dependent. As a result, no credit was taken for the potential sale of CFB boiler ash. The EGas Plant produces both elemental sulfur and slag; similar to the CFB boiler ash, the slag was assumed to have no value, whereas, the sulfur is considered a byproduct of the plant that can be sold for $\$ 75 /$ ton. 
Table 3.5.11.1 Consumable Unit Costs

\begin{tabular}{|l|c|}
\hline & Unit Cost \\
\hline Water per 1,000 gals & $\$ 0.82$ \\
\hline Chemicals & \\
\hline Water Treatment per lb & $\$ 0.20$ \\
\hline Limestone per Ton & $\$ 18.00$ \\
\hline COS Catalyst per CuFt & $\$ 0.00$ \\
\hline Shift Catalyst per CuFt & $\$ 450.00$ \\
\hline Claus Catalyst per CuFt & $\$ 325.00$ \\
\hline Hdrogenation Catalyst per CuFt & $\$ 290.00$ \\
\hline Amine per lb & $\$ 1.09$ \\
\hline Ammonia per lb & $\$ 0.22$ \\
\hline Other & $\$ 15.00$ \\
\hline Supplemental Fuel per MMBtu & \\
\hline & \\
\hline Waste Disposal & $\$ 12.00$ \\
\hline Ash per ton & $\$ 12.00$ \\
\hline Slag per ton & \\
\hline
\end{tabular}

\subsubsection{By-Product Credits}

The electricity produced by both plants and the elemental sulfur produced by the E-Gas based plant are sold to produce a "by-product" revenue stream for their plants. Electricity and sulfur yearly production rates are based on a 90 percent plant capacity factor and their sell prices are assumed to escalate at 2.5 percent per year from year 2005 values of $\$ 45$ per MWhr and $\$ 75$ per ton respectively.

\subsubsection{Fuel Cost}

The fuel cost is based on the plant full load coal flow rate with the plant operating 24 hours per day 365 days per year and an overall capacity factor of 90 percent. Coal costs are assumed to escalate at 0.1 percent per year from a year 2005 value of $\$ 1.61$ per million Btu.

\subsubsection{Total Production Cost}

This is the sum of fixed O\&M, variable O\&M, fuel, and consumables costs less by-product credits. It is presented on both a first year (2009) and a levelized 10-year basis.

\subsubsection{Carrying Charges}

This is the sum of return on debt, 12 percent return on equity, federal and state income taxes, book depreciation, property taxes, and insurance. It is presented on a levelized 10-year basis.

\subsubsection{Cost of Hydrogen}

The revenue requirement method is widely used in the electric utility industry to perform an economic analysis of a prospective new power plant. This method permits the various dissimilar 
components of a new plant to be incorporated into a value that can be compared with various alternatives. From a cost of electricity standpoint the revenue requirement figure-of-merit is the levelized (over plant life) coal pile-to-bussbar cost of electricity expressed in mills/kWh. The value, based on EPRI definitions and methodology, includes the TCR, which is represented in the levelized carrying charge (sometimes referred to as the fixed charges), 10-year levelized fixed and variable operating and maintenance costs, 10-year levelized consumables operating costs, and 10 year levelized fuel cost.

A similar revenue requirement analysis was performed to determine the cost of producing hydrogen on a dollar per million Btu basis; in this analysis, however, credit was included for the sale of the electricity and sulfur co-produced with the hydrogen.

The bases for calculating plant capital investment and revenue requirements are given in Figure 3.5.4.1. The total plant cost (TPC) and revenue requirement (hydrogen production cost), are the principal cost and economic outputs of the study.

The levelized carrying charge, applied to TCR, establishes the required revenues to cover return on equity, interest on debt, depreciation, income tax, property tax, and insurance. Levelizing factors are applied to the first-year fuel, O\&M, and consumables costs to yield 10-year levelized costs. A long-term inflation rate of 2.5 percent per year was assumed in estimating the cost of capital and in estimating the life-cycle revenue requirements for other expenses (except that fuel was escalated at 0.1 percent per year).

To represent these varying revenue requirements for fixed and variable costs, a "levelized" value was computed using the "present worth" concept of money based on the assumptions shown in Table 3.5.2.1.By combining costs, by-product credits, and carrying charges a levelized 10 year cost of producing hydrogen was calculated by the following:

Levelized Hydrogen

Production Cost $\quad=(\mathrm{LCC}+\mathrm{LFOM}+\mathrm{LVOM}+\mathrm{LCM}-\mathrm{LLB}+\mathrm{LFC}) /$ Tons of Hydrogen Produced*

LCC = Levelized Carrying charge, $\$ / \mathrm{yr}$

LFOM = Levelized Fixed O\&M, \$/yr

LVOM = Levelized Variable O\&M, \$/yr

LCM = Levelized Consumables*, $\$ / y r$

LBPC = Levelized By-product credit* (if any), \$/yr

LFC = Levelized Fuel costs*, \$/yr

* all for a 90 percent plant capacity factor 


\subsection{Entrained Flow Gasifier Based Co-Production Plant}

\subsection{Plant Overview, Performance, and Emissions}

\section{$\underline{\text { Overview }}$}

Figure 4.1.1 is a simplified a process block diagram of the entrained flow gasifier co-production

plant conceptually designed by Parsons. The plant incorporates three 50 percent capacity gasifier equipment trains. Although the trains operate in parallel at identical conditions, only two trains are in steady state operation at any point in time. The first operating train provides syngas for hydrogen production, whereas, the second train provides syngas for power generation. In the 1990s coal fueled, single train, entrained flow IGCC demonstration plants were built by several different manufacturers. Depending upon the plant, and despite several yeas of operation, plant availabilities are in 70s and 80s percent. To achieve a plant availability of at least 90 percent, the plant has been provided with a spare gasifier equipment train [2-1], [2-2]. This spare or third train is physically located along side of the other two; it is brought on line for either hydrogen or power generation when one of the other two trains has been shut down for maintenance. To allow for future component improvements/advances, the economics of the entrained flow co-production plant have been determined both with and without the spare train.

All three gasifiers are oxygen blown and operate with coal injected as a 35 weight percent coal 65 weight percent water slurry. The gasifiers draw their oxygen from a common header supplied by two 50 percent capacity, conventional, cryogenic ASUs. Two 100 percent capacity milling systems crush the coal to size, mix it with water, and deliver it to two product tanks for transfer to the plant's three slurry feed tanks. Each 50 percent capacity gasifier equipment train consists of a coal-water slurry feed tank, slurry pumps, a slurry heater, a two stage entrained flow gasifier, a slag rejection system, a fire tube boiler/syngas cooler, a cyclone, a candle filter, a water scrubber, and a fines return system. The gasifiers operate at identical conditions and produce 514 psia $1750^{\circ} \mathrm{F}$ syngas that is cleaned of gas entrained particulate and cooled to $285^{\circ} \mathrm{F}$ by the downstream equipment. After cooling, twenty percent of the syngas is compressed and used to transport the char fines, captured by the cyclone and filter, back to and into the gasifier to increase the gasifier carbon conversion efficiency. The remaining 80 percent then proceeds to its respective gas processing section.

The syngas from the first gasifier train proceeds to the hydrogen production equipment train where it undergoes steam injection, reheating, three stages of water gas shifting (two high temperature and one low temperature), gas cooling, amine washing for acid gas removal (AGR), and PSA. The PSA system separates the hydrogen from the syngas and yields 99.95 percent pure, 370 psia, $117^{\circ} \mathrm{F}$ hydrogen for sale to a near by refinery at a rate of $21,731 \mathrm{lb} / \mathrm{hr}$ (261 tons/day). The $\sim 20 \mathrm{psia}$ low Btu vent/purge gas from the PSA is fired in a boiler that generates steam for process use and to drive a 50.1 MWe steam turbine; in generating this steam the flue gas from the boiler is cooled to $250^{\circ} \mathrm{F}$ and discharged to one of the plant's two stacks. 


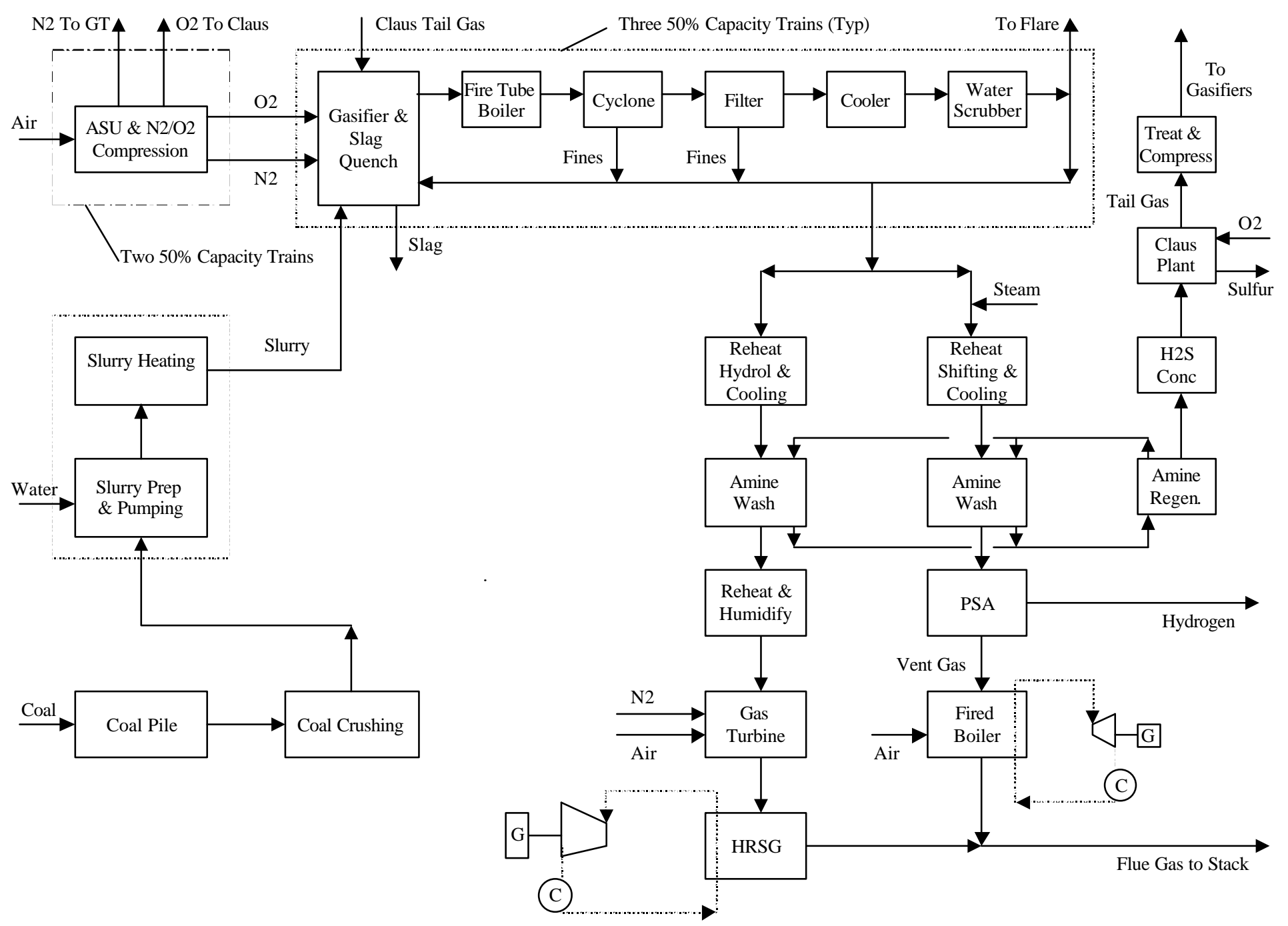

Figure 4.1.1 Entrained Flow Plant Process Block Diagram 
The syngas from the second train proceeds to the power generation equipment train where it undergoes reheating, COS hydrolysis, cooling, an amine AGR wash, reheating, and humidification; the humidified gas at 390 psia and $535^{\circ} \mathrm{F}$ fuels a General Electric 7FA gas turbine that generates $190 \mathrm{MWe}$. A heat recovery steam generator (HRSG) downstream of the gas turbine cools the $1057^{\circ} \mathrm{F}$ turbine exhaust to $278^{\circ} \mathrm{F}$, produces steam to drive a $98.9 \mathrm{MWe}$ steam turbine, and discharges its gas to the second, larger plant stack.

The amine washes strip the syngas streams of their hydrogen sulfide and, in doing so, absorb other gases. The rich/used amine solvent from each absorber is pumped to a common tower where steam stripping releases the absorbed gases. The regenerated/lean solvent is then pumped back to each absorber, whereas, the stripper off gas undergoes another amine wash designed to separate the hydrogen sulfide from the other gases. With much of the other gases removed, the hydrogen sulfide rich gas proceeds to a Claus furnace where it is burned with oxygen. The exhaust/tail gas from the Claus furnace is cooled to condense/remove sulfur, hydrogenated, cooled again, compressed, and injected back into the gasifiers.

\section{Performance}

Figures 4.1.2 and 4.1.3 identify the flow rates, pressures, and temperatures of the plant's air/gas side flow paths; syngas, char fines, and slag compositions are not shown as they are considered EGas proprietary data. Tables 4.1.1 and 4.1.2 present the plant performance and parasitic power loads as determined by Parsons; the gas and steam turbines have a combined gross power output of 346.0 MWe and, with a parasitic power draw of 94.1 MWe, results in a net plant output of 251.9 MWe. To generate this power and produce $21,703 \mathrm{lb} / \mathrm{hr}$ of hydrogen the plant consumes coal at the rate of $368,938 \mathrm{lb} / \mathrm{hr}$ and operates with an effective thermal efficiency of 47.6 percent (HHV basis). 


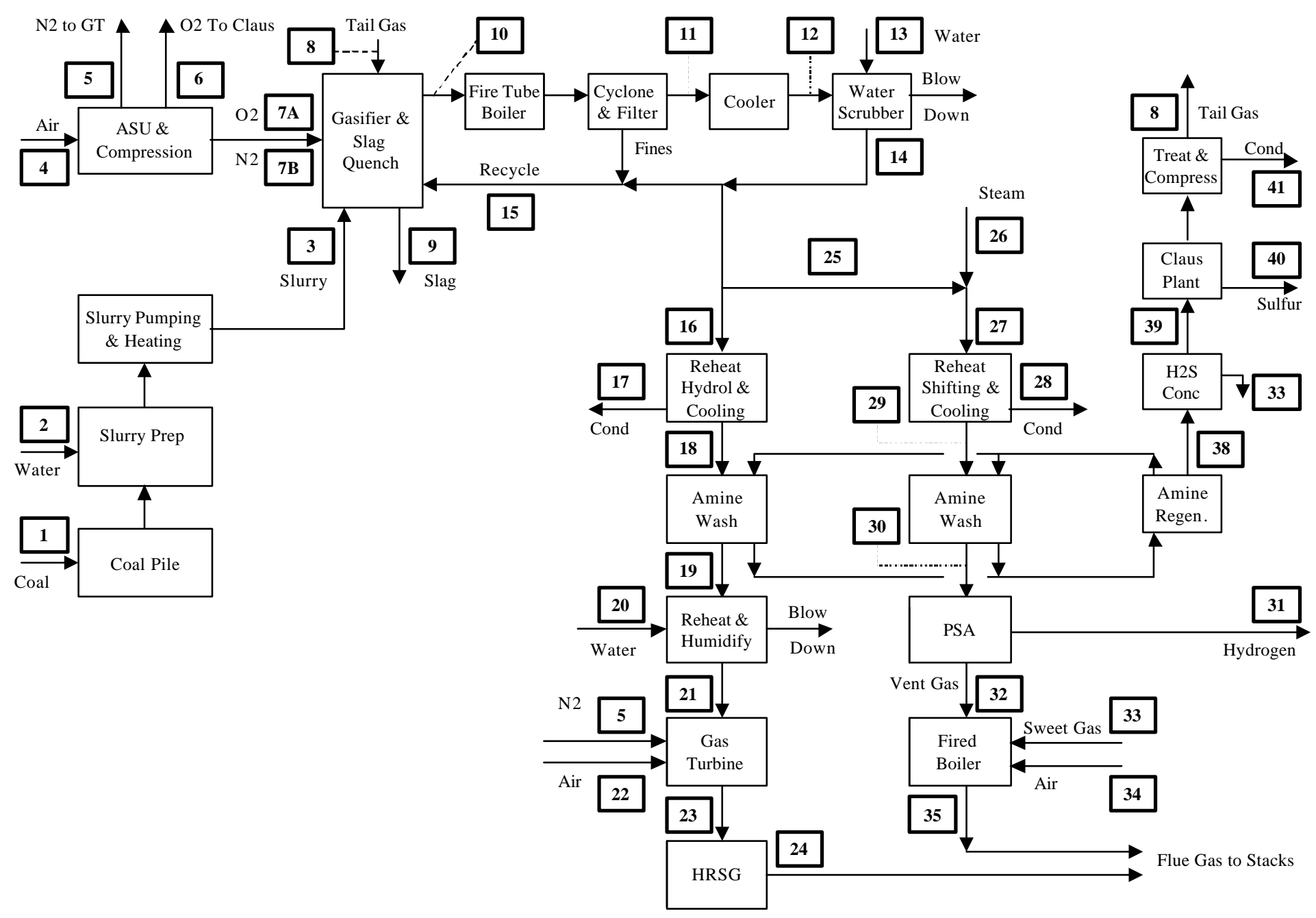

Figure 4.1.2 Entrained Flow Plant Process Stream Locations 


\begin{tabular}{|c|c|c|c|c|c|c|c|c|c|c|c|}
\hline Stream Number & & 1 & 2 & 3 & 4 & 5 & 6 & $7 \mathrm{~A}$ & $7 \mathbf{B}$ & 8 & 9 \\
\hline Stream Location & & Slurry Prep & Slurrv Prep & Gasifier & ASU & ASU & ASU & Gasifier & Gasifier & Gasifier & Gasifier \\
\hline Temperature, $\mathrm{F}$ & & 59 & 59 & 300 & 59 & 296 & 90 & 205 & 360 & 861 & 250 \\
\hline Pressure, psi & & 14.7 & 14.7 & 550.0 & 14.7 & 359.0 & 30.0 & 815.0 & 600 & 750.0 & 14.7 \\
\hline \multirow{3}{*}{$\begin{array}{l}\text { Medium } \\
\text { Flow Rate, Klb/hr }\end{array}$} & & coal & water & slurry & air & nitrogen & oxygen & oxygen & nitrogen & Claus tail gas & slag \\
\hline & $\begin{array}{r}\text { Gas } \\
\text { Solids }\end{array}$ & 368.938 & & 368.938 & 1293.428 & 482.811 & 4.995 & 291.846 & 3.787 & 46.333 & 37.934 \\
\hline & Liquid & & 164.602 & 164.602 & & & & & & & \\
\hline Total Flow, Klb/hr & & 368.938 & 164.602 & 533.540 & 1293.428 & 482.811 & 4.995 & 291.846 & 3.787 & 46.333 & 37.934 \\
\hline Stream Number & & 10 & 11 & 12 & 13 & 14 & 15 & 16 & 17 & 18 & 19 \\
\hline Stream Location & & Gasifier & Filter Outlet & Scrubher & Scrubher & Scruhber & Gasifier & Power Train & Drains & AfRR & $A \cap R$ \\
\hline Temperature, F & & 1750 & 690 & 330 & 150 & 285 & 365 & $390 * * *$ & varies & 103 & 110 \\
\hline Pressure, psi & & 514.4 & 484.2 & 465.2 & 465.2 & 447.7 & 605.0 & 447.7 & varies & 412.7 & 402.7 \\
\hline Medium & & mixture & syngas & syngas & water & syngas & syngas & syngas & condensate & syngas & syngas \\
\hline \multirow[t]{2}{*}{ Flow Rate, Klb/hr } & $\begin{array}{r}\text { Gas } \\
\text { Solids }\end{array}$ & $\begin{array}{c}1039.352 \\
*\end{array}$ & 1039.352 & 1039.352 & & 989.969 & $\begin{array}{c}197.994 \\
*\end{array}$ & 395.988 & & 365.661 & 338.492 \\
\hline & Liquid & & & & 5.180 & & & & 30.326 & & \\
\hline Total Flow, Klb/hr & & 1039.352 & 1039.352 & 1039.352 & 5.180 & 989.969 & 197.994 & 395.988 & 30.326 & 365.661 & 338.492 \\
\hline Stream Number & & 20 & 21 & 22 & 23 & 24 & 25 & 26 & 27 & 28 & 29 \\
\hline Stream Location & & Humidifier & GiT Burner & GT Inlet & GT Fxhanst & HRSG Outlet & H). Train & H). Train & HT Shift Inlet & Drains & ACRR \\
\hline Temperature, $\mathrm{F}$ & & 150 & 535 & 59 & 1057 & 278 & 285 & 500 & $550 * *$ & varies & 103 \\
\hline Pressure, psi & & 445.0 & 390.0 & 14.7 & 15.1 & 14.8 & 447.7 & 500.0 & 442.7 & varies & 389.8 \\
\hline Medium & & water & syngas & air & exhaust & exhaust & syngas & steam & syngas & water & syngas \\
\hline \multirow[t]{3}{*}{ Flow Rate, Klb/hr } & & & 400232 & 2027510 & & & 205098 & 01154 & & & \\
\hline & $\begin{array}{r}\text { Gas } \\
\text { Solids }\end{array}$ & & 402.322 & 3237.510 & $4,122.643$ & $4,122.643$ & 395.988 & 211.514 & 607.502 & & 496.646 \\
\hline & Liquid & 68.932 & & & & & & & & 110.856 & \\
\hline Total Flow, Klb/hr & & 68.932 & 402.322 & 3237.510 & 4122.643 & $4,122.643$ & 395.988 & 211.514 & 607.502 & 110.856 & 496.646 \\
\hline Stream Number & & 30 & 31 & 32 & 33 & 34 & 35 & $38+$ & 39 & 40 & 41 \\
\hline Stream Location & & AGR & PSA Outlet & PSA Outlet & Fired Boiler & Fired Boiler & Fired Boiler & Regenerator & Claus Plant & Claus Plant & Tail Gas Unit \\
\hline Temperature, F & & 110 & 117 & 97 & 105 & 59 & 250 & 103 & 120 & 270 & 120 \\
\hline Pressure, psi & & 378 & 369.8 & 19.4 & 20.0 & 14.7 & 15.5 & 382 & 30.0 & 14.7 & 167 \\
\hline \multirow{3}{*}{$\begin{array}{l}\text { Medium } \\
\text { Flow Rate, Klb/hr }\end{array}$} & & syngas & hydrogen & PSA vent & sweet gas & air & flue gas & & conc $\mathrm{H} 2 \mathrm{~S}$ & sulfur & condensate \\
\hline & $\begin{array}{r}\text { Gas } \\
\text { Solids }\end{array}$ & 341.522 & 21.703 & 319.739 & 137.106 & 687.736 & $1,147.842$ & 182.372 & 45.266 & 10.590 & \\
\hline & Liquid & & & & & & & & & & 3.448 \\
\hline Total Flow, Klb/hr & & 341.522 & 21.703 & 319.739 & 137.106 & 687.736 & 1147.842 & 182.372 & 45.266 & 10.59 & \\
\hline *not disclosed & & after reheat & & -Stream Number & $\& 37$ deleted & & & & & & \\
\hline
\end{tabular}

Figure 4.1.3 Entrained Flow Plant Process Stream Operating Conditions 
Table 4.1.1 E-Gas Entrained Flow Plant Performance Data

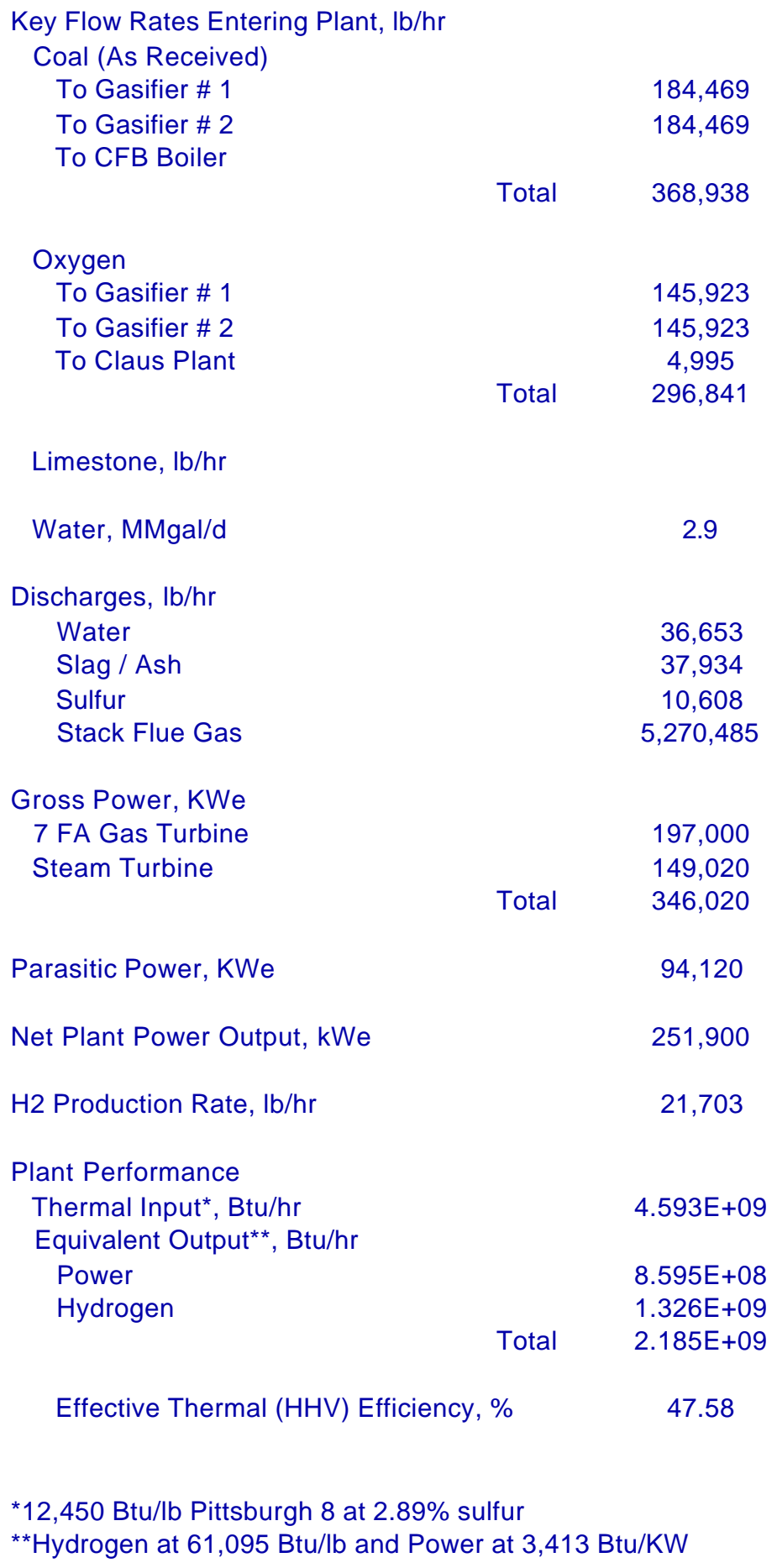


Table 4.1.2 E-Gas Entrained Flow Plant Parasitic Power (KWe)

Coal/Limestone Handling

Gasifier Coal Milling

Coal Slurry Pumps

Slag Handling and Dewatering

Air Separation Unit Auxiliaries

Oxygen Compressor

Main Nitrogen Compressor

Fines Recycle Gas Blower

Tail Gas Recycle Blower

Fired Boiler Air Fan

Condensate Pumps

HP Boiler Feedwater Pump

LP Boiler Feedwater Pump

Circulating Water Pump

Cooling Tower Fans

Humidification Tower Pump

Humidification Makeup Pump

Flash Bottoms Pump

Scrubber Pumps

Amine Unit Auxiliaries

Claus Plant/TGTU Auxiliaries

Gas Turbine Auxiliaries

Steam Turbine Auxiliaries

Transformer Losses

Miscellaneous Balance-of-Plant

Totals

${ }^{\star}$ Totals by Process Area
H2 Train

230

470

200

190

15,600

8,580

840

1,330

1,250

100

570

80

740

460

50

400

970

200

970

200

400

400

750

1,900

1,000

1,000

2,000

33,610

60,510

94,120

400

600

900

4,340

1,250

6,120

100

80

150

800

1,130

1,940

400

94,120 


\section{Emissions}

The emissions of the entrained flow plant are the total of those contained in the exhaust from its GE 7FA gas turbine and its PSA vent gas fired boiler. The Wabash IGCC Demonstration Plant, which incorporated an E-Gas gasifier, an amine scrubber for sulfur capture, a Claus Plant for sulfur recovery, and a GE 7FA gas turbine, operated with $\mathrm{SO}_{2}$ and $\mathrm{NOx}$ emissions rates of 0.13 and $0.08 \mathrm{lb} / \mathrm{MMBtu}$ respectively [4-1]. To reduce those emission rates, the entrained flow gasifier based plant recycles the Claus Plant tail gas back to the gasifier and injects nitrogen into the gas turbine combustor. Parsons projects that these steps will reduce the co-production plant $\mathrm{SO}_{2}$ emission rate to $0.023 \mathrm{lb} / \mathrm{MMBtu}$ (99.5 percent sulfur capture efficiency) and the NOx emission rate to $0.067 \mathrm{lb} / \mathrm{MMBtu}(15 \mathrm{ppmvd})$. Using these new values, together with those projected for the PSA vent gas fired boiler, Parsons determined the plant emissions on a pound per hour basis and then expressed them on a total plant heat input basis; Parsons' plant emission estimate is given in Table 4.1.3

Table 4.1.3 E-Gas Entrained Flow Plant Emissions

\begin{tabular}{|c|c|c|c|}
\hline & $\begin{array}{l}\text { Gas } \\
\text { Turbine }\end{array}$ & $\begin{array}{l}\text { Fired } \\
\text { Boiler }\end{array}$ & $\begin{array}{l}\text { Plant } \\
\text { Totals }\end{array}$ \\
\hline \multicolumn{4}{|l|}{ SO2 } \\
\hline \% Capture & & & 99.5 \\
\hline $\mathrm{lb} / \mathrm{hr}$ & & & 106.9 \\
\hline lb/MMBtu & & & 0.023 \\
\hline \multicolumn{4}{|l|}{ NOx } \\
\hline $\mathrm{lb} / \mathrm{hr}$ & 122 & 72 & 194 \\
\hline $\mathrm{lb} / \mathrm{MMBtu}$ & 0.066 & & 0.042 \\
\hline \multicolumn{4}{|l|}{$\mathrm{CO}$} \\
\hline $\mathrm{lb} / \mathrm{hr}$ & 203 & 94 & 297 \\
\hline $\mathrm{lb} / \mathrm{MMBtu}$ & 0.110 & 0.200 & 0.065 \\
\hline \multicolumn{4}{|l|}{ Particulate } \\
\hline $\mathrm{lb} / \mathrm{hr}$ & & & 3.7 \\
\hline lb/MMBtu & & & 0.0008 \\
\hline
\end{tabular}

\subsection{Process and System Description}

The entrained plant consists of numerous systems that work together to produce hydrogen and electricity. For cost estimating purposes those systems have been divided into 14 processing blocks or cost accounts that are presented in Appendix A. In addition to facilitating cost estimating, these accounts also facilitate a detailed process description of the plant as follows:

\section{Coal Receiving and Handling}

Pittsburgh No 8 coal, crushed to a 6 inch by zero size, is delivered to the site in 100 car unit trains. The coal is unloaded, moved to the storage pile, and reclaimed by the conventional equipment listed in Account 1; included in this account is a trestle bottom dumper, receiving hoppers, feeders, conveyors, and stacker/reclaimer. The reclaimed coal is crushed to a 1 inch by zero size in two steps and transferred to two three-day storage silos that supply coal to the coal-water slurry preparation and feeding subsystems. 


\section{Coal-Water Slurry Preparation and Feeding}

The coal-water slurry preparation and feeding equipment is listed in Account 2 . Slurry preparation equipment consists of two 100 percent capacity trains of day silos, rod mills, and slurry product tanks that operate in parallel, crush one inch by zero coal to a minus 200 mesh size, and mix it with water to form a 35 weight percent coal - 65 weight percent water slurry. From the product tanks the slurry is pumped to three 50 percent capacity feed trains, each connected to a gasifier and consisting of a slurry storage feed tank, slurry pumps, and slurry heaters. Each feed train can deliver slurry to its respective gasifier at a full load flow rate of $266,770 \mathrm{lb} / \mathrm{hr}$ at $500 \mathrm{psia}$ and $300^{\circ} \mathrm{F}$.

\section{Oxygen and Nitrogen Supply Systems}

The plant utilizes two 50 percent capacity oxygen supply systems that operate in parallel at identical conditions. Each of the two oxygen supply system incorporates an electrically driven compressor that supplies 70 psia $210^{\circ} \mathrm{F}$ air to a conventional, cryogenic ASU. The ASU includes a liquid oxygen storage tank to guard against short term disruptions and each ASU supplies 95 percent pure oxygen to its own electrically driven boost compressor. The latter pressurizes the $60^{\circ} \mathrm{F}$ oxygen from 15 to 815 psia and discharges to a header shared with the other boost compressor; the two operating and one spare 50 percent capacity gasifiers draw their oxygen from this supply header at a total rate of $291,846 \mathrm{lb} / \mathrm{hr}$. The ASUs also supply a small stream of $60^{\circ} \mathrm{F}$ oxygen $(4,995 \mathrm{lb} / \mathrm{hr})$ to the Claus Furnace.

The gas turbine requires nitrogen injection to control its NOx emissions. As a result, $60^{\circ} \mathrm{F}$ nitrogen from the ASU is compressed to 359 psia for delivery to the gas turbine burner at a rate of 482,811 $\mathrm{lb} / \mathrm{hr}$; a slip stream of nitrogen from the ASU is also compressed and available for miscellaneous plant uses.

The equipment making up the oxygen and nitrogen supply systems are listed in Account 4B.

Entrained Flow Gasifier

The plant utilizes three 50 percent capacity gasifiers (see Account $4 \mathrm{~A}$ for equipment) that operate in parallel at identical conditions but independent of each other. The first produces syngas for hydrogen production, the second produces syngas for electric power generation, and the third is a spare that can be used for either hydrogen or power production when one of the other gasifiers is shut down. The gasifiers are entrained flow type units as exemplified by the E-Gas ${ }^{\mathrm{TM}}$ gasifier at the Clean Coal Technology Wabash River Repowering Project. Each gasifier is a two stage unit and its $266,770 \mathrm{lb} / \mathrm{hr}$ slurry feed is split between the first and second stages. Typically the slurry proportions 78 percent to the $\sim 2500^{\circ} \mathrm{F}$ first stage, and 22 percent to the second stage. Oxygen is delivered to each gasifier at a full load rate of $145,923 \mathrm{lb} / \mathrm{hr}$ and, because of the high temperature of the first stage, a molten slag is produced that collects on and runs down the walls of the unit. At the bottom, the molten slag drains to a water bath, solidifies, sinks to the bottom of the bath, is removed from the process, crushed, and transferred to storage silos for disposal. The slurry injected in the second stage of the unit cools the syngas and the gas exits from the top of the unit at $514 \mathrm{psia}$ and $1750^{\circ} \mathrm{F}$ at a rate, excluding entrained particulate/char fines, of 519,676 lb/hr. After cooling, the collected char fines are injected back into the first stage of the gasifier with cold $\left(285^{\circ} \mathrm{F}\right)$ recycled syngas. 


\section{Syngas Cooling and Particulate Removal}

After exiting the gasifier the syngas flows vertically down the tubes of a fire-tube type boiler/ syngas cooler, which, by the generation of steam, cools the syngas and entrained particulate to $690^{\circ} \mathrm{F}$. The cooled syngas proceeds to a cyclone that pre-cleans the gas/removes the coarser particulate before the gas enters a candle filter for the removal of all remaining particulate. The filter consists of an array of vertical hanging, porous, ceramic candles located inside of a pressure vessel. Similar to a bag house filter, the particulate collect on the outside of the candles. On reaching a predetermined pressure drop, the candles are cleaned (dust blown off) by a back-pulse of clean gas (recycled syngas) and the particulate fall to and drain from the bottom of the vessel. A surge hopper is provided both under the cyclone and under the filter to collect their respective coal and char particles. The collected material is transported back to and injected into the gasifier using recycled cold syngas.

After exiting their respective candle filters the two $690^{\circ} \mathrm{F}$ syngas streams are separately cooled to $285^{\circ} \mathrm{F}$ via tubular heat exchangers and a water scrubber and passed through a series of valves that control the gasifier pressure, divert syngas to flare, isolate the gasifier from downstream components and the spare gasifier train, and provides 20 percent syngas recirculation to transport char, collected by the pre-cleaner cyclone and filter, back to the gasifier.

The syngas cooling and particulate removal equipment is included in Account 4A.

\section{Syngas for $\mathrm{H}_{2}$ Production}

This stream is processed by the equipment listed in Account 5A. After passing through the water scrubber, the syngas undergoes steam injection, reheat to $550^{\circ} \mathrm{F}$, and three stages of water gas shifting. Since the water gas shift reaction is exothermic a series of heat exchangers control the syngas temperature and ultimately reduce it to $110^{\circ} \mathrm{F}$ for delivery to a conventional PSA system for separation of the hydrogen. Condensate, formed during this cooling, contains varying amounts of contaminants i.e. $\mathrm{H}_{2} \mathrm{~S}, \mathrm{NH}_{3}, \mathrm{HCl}$, etc. and this "gray water" is sent to a central water treatment system for contaminant removal by steam stripping; after cleaning, the water is supplied to the slurry preparation system and the stripping off-gas is sent to the Claus furnace. Despite the condensation, a considerable amount of contaminants will remain in the cooled syngas. Although the PSA will prevent them from contaminating the hydrogen, their presence in the PSA vent gas, which is burned in the fired boiler, can cause a stack gas emission problem. To prevent this, the syngas undergoes acid gas removal before delivery to the PSA.

The acid gas removal system appears under Account 5B; it consists of a single stage amine absorption tower that strips the syngas of $\mathrm{H}_{2} \mathrm{~S}$. With the $\mathrm{H}_{2} \mathrm{~S}$ removed, the syngas proceeds to the PSA system at a rate of $341,522 \mathrm{lb} / \mathrm{hr}$. The PSA separates the hydrogen and releases it at 369.8 psia for delivery/sale to the refinery at a rate of $261 \mathrm{tpd}$. The $319,739 \mathrm{lb} / \mathrm{hr}$ of $19.4 \mathrm{psia}$ low Btu PSA purge/vent gas is burned along with $137,106 \mathrm{lb} / \mathrm{hr}$ of sweet gas with $687,736 \mathrm{lb} / \mathrm{hr}$ of air in a fired boiler that discharges $250^{\circ} \mathrm{F}$ flue gas to the smaller of the plant's two stacks.

The fired boiler, together with the various upstream gas coolers, generates steam at several different pressure levels for process use and to drive a 50.1 MWe steam turbine. The latter 
operates with a $408,296 \mathrm{lb} / \mathrm{hr} 950^{\circ} \mathrm{F} 1250$ psig throttle flow. The fired boiler and steam turbine are included under Account 7.

Syngas for Power Production

This stream is processed by the equipment listed in Account $5 \mathrm{C}$. After exiting its water scrubber, the syngas is reheated to $390^{\circ} \mathrm{F}$, passed through a COS hydrolysis unit to convert $\mathrm{COS}$ to $\mathrm{H}_{2} \mathrm{~S}$, cooled to $103^{\circ} \mathrm{F}$, and delivered to an amine absorption tower for removal of acid gases. The amine absorber strips the syngas of $\mathrm{H}_{2} \mathrm{~S}$ and the cleaned syngas is humidified and reheated to $535^{\circ} \mathrm{F}$ for delivery to the gas turbine combustor.

Condensate is formed during the cooling of the syngas to $103^{\circ} \mathrm{F}$ and the condensate contains contaminants i.e. $\mathrm{HCN}, \mathrm{NH}_{3}$, halogens ( $\mathrm{HCl}$ and $\mathrm{HF}$ ), etc. and this "gray water" is sent to a central water treatment system; after cleaning, the water is supplied to the slurry preparation system and the stripping off-gas is sent to the Claus furnace.

\section{$\underline{\mathrm{H}}_{2} \underline{\mathrm{S} \text { Processing }}$}

The $\mathrm{H}_{2} \mathrm{~S}$ processing equipment is listed in Account $5 \mathrm{C}$. The $\mathrm{H}_{2} \mathrm{~S}$ rich amine solvent streams from the hydrogen and power production acid gas removal sections are pumped to a common tower/reboiler where, after mixing, they are steam stripped/heated with 45,210 lb/hr of 65 psia steam; this releases hydrogen sulfide and other absorbed gases and allows the amine, now regenerated (lean solvent), to be pumped back to their respective absorber towers for continued use. The hydrogen sulfide content of the reboiler off-gas is less than optimum for the Claus furnace sulfur recovery and the gas undergoes another wash to remove the extraneous gases. The reboiler associated with this concentrating wash consumes another 12,691 lb/hr of 65 psia steam and the hydrogen sulfide rich off-gas is delivered to and burned with oxygen in the Claus furnace. The Claus furnace exhaust gas is passed through a series of coolers and catalytic reactors to recover elemental sulfur for sale as a by-product of the plant. Since sulfur recovery is not 100 percent, the gas, after cooling to $318^{\circ} \mathrm{F}$, is hydrogenated, cooled, compressed, and injected back into the gasifiers at $861^{\circ} \mathrm{F}$.

\section{Gas Turbine}

The plant incorporates a single General Electric Model 7FA combustion turbine that is listed under Account 6 . The gas turbine is fueled with $402,322 \mathrm{lb} / \mathrm{hr} 535^{\circ} \mathrm{F}, 390 \mathrm{psia}$, humidified syngas produced/processed by the syngas power production section of the plant. Nitrogen, supplied by the ASU, is injected into the gas turbine combustion process at a rate of $482,811 \mathrm{lb} / \mathrm{hr}$ to control NOx emissions. The machine is an axial flow, constant speed unit possessing variable inlet guide vanes. and produces 197 MWe of power.

\section{Heat Recovery Steam Generator}

The gas turbine discharges $1057^{\circ} \mathrm{F}$ exhaust gas to a heat recovery steam generator (HRSG) at a rate of 4,122,643 lb/hr. The HRSG is a three pressure unit containing high pressure (HP), intermediate pressure (IP), and low pressure (LP) steam drums. The HRSG cools the gas turbine exhaust to $278^{\circ} \mathrm{F}$ and, working in conjunction with the syngas cooler and other gas coolers, produces $1005^{\circ} \mathrm{F}$ superheat and reheat steam to drive a steam turbine. The flue gas from the HRSG discharges to the plant's second and larger stack. The HRSG and stack are listed under Account 7. 


\section{Fired Boiler}

The fired boiler and its auxiliary equipment are also listed under Account 7 . The fired boiler is fueled with the 19.4 psia low Btu vent gas/tail gas from the PSA at the rate of 319,739 lb/hr and, in addition, receives the $137,106 \mathrm{lb} / \mathrm{hr}$ sweet gas from the $\mathrm{H}_{2} \mathrm{~S}$ concentration step. Air supplied by a fan at the rate of $687,736 \mathrm{lb} / \mathrm{hr}$ and $78^{\circ} \mathrm{F}$ supports the combustion of the vent gas and the boiler cools the combustion exhaust gas to $250^{\circ} \mathrm{F}$. Working together with the upstream syngas cooler and other gas coolers, the fired boiler produces steam for process use and to drive a small steam turbine. The flue gas from the waste heat boiler, cooled to $250^{\circ} \mathrm{F}$, discharges to the smaller of the plant's two stacks.

\section{Steam Turbines and Steam Condensers}

As listed under Account 8 the plant incorporates two steam turbine generators and two steam condensers that operate in parallel and independent of each other; the larger one produces 98.9 MWe of power and is part of the power production section of the plant; the other produces 50.1 MWe of power and is part of the hydrogen production part of the plant. The former is supplied with $1600 \mathrm{psig} 1000^{\circ} \mathrm{F}$ steam from the gas turbine HRSG at a rate of 589,262 lb/hr and incorporates a single stage of reheat to $1000^{\circ} \mathrm{F}$. It consists of tandem HP, IP, and LP sections connected via a common shaft that drives a 3,600 RPM hydrogen cooled generator. The generator is a synchronous type unit that operates with an efficiency of 98 percent.

The smaller steam turbine is supplied with $1250 \mathrm{psig} 950^{\circ} \mathrm{F}$ steam from the fired boiler at a rate of $408,296 \mathrm{lb} / \mathrm{hr}$. Being a relatively small unit, there is no reheat and it produces only $50.1 \mathrm{MWe}$ of power.

A single pass, horizontal type condenser is provided under each steam turbine to condense their exhaust steam and provide condensate to their respective feedwater heating systems. The larger condenser supports the power generation section of the plant and condenses steam at a rate of $530,284 \mathrm{lb} / \mathrm{hr}$ at a back pressure of $1 \mathrm{psia}$; the smaller unit supports the hydrogen section of the plant and condenses steam at a rate of $408,296 \mathrm{lb} / \mathrm{hr}$ at $1 \mathrm{psia}$. In both units the steam is indirectly cooled by heating circulating water for delivery to a mechanical draft cooling tower.

\section{Condensate and Feedwater Systems}

The heated discharge water from each condenser proceeds to a common, mechanical draft, evaporative cooling tower that transfers the heat of condensation to the atmosphere. The cooling tower consists of multiple cells that are operated as required to meet the plant cooling load.. Four 50 percent capacity circulating water pumps (two for the small condenser and two for the large condenser) pump cooled water to the condensers. This equipment is listed under Account 9.

Each condenser is provided with two 50 percent capacity motor driven pumps that extract condensate from their respective hot wells and pump it to deaerating sections/tanks. Each tank in turn is provided with two 50 percent capacity motor driven boiler feed pumps that supply feedwater to their respective boilers. This equipment is listed under Account 3A. 


\subsection{List of Plant Major Equipment}

The major pieces of equipment required by the three gasification train co-production plant have been subdivided into 14 accounts and are tabulated in Appendix A; those 14 accounts served as the basis for the plant cost estimates presented in Section 4.4.

\subsection{Plant Costs and Economic Analysis}

Parsons is an architect engineering company that designs and supplies a variety of plants including those directed at power production, chemical production, and petrochemical refining. This background gives them an extensive database for estimating equipment supply and erection costs, plant performance, and overall plant costs. As a result, Parsons has conducted numerous studies for the DOE in which they conceptually designed and determined the performance and economics of IGCC plants designed for power production or hydrogen production. In these studies the gasifier developer provided performance, size, and cost data for its component(s) and Parsons sized the balance of the equipment required by the plant and determined overall plant costs and economics. Using cost data from these previous studies together with "in-house" data, Parsons determined the cost and economics of the entrained flow gasifier based co-production plant in accordance with the methodology presented in Section 3.5.

Table 4.4.1 presents the cost of E-Gas co-production plant by account total (for costs at the subaccount level the reader is referred to Appendices A and B - the plant with and without a spare gasifier equipment train). When provided with a spare train of gasification equipment (total of 3 trains), Parsons estimates the plant will have a total plant cost of $\$ 678.5$ million in year 2005 dollars. Allowing for technology and reliability improvements that may allow deletion of one train of gasification equipment, the plant cost reduces to $\$ 647.8$ million. Consumables and operating requirements and costs are presented in Tables 4.4.2 and 4.4.3. The economics of the plants are presented in detail in Tables 4.4.4 and 4.4.5. Table 4.4.6 summarizes the key economic data of both plants; the 251.9 MWe of power and 10,608 $\mathrm{lb} / \mathrm{hr}$ of sulfur produced by the plant, which are assumed to be sold for $\$ 45 / \mathrm{MWhr}$ and $\$ 75 /$ ton respectively, provide valuable revenue streams that enable the plants to sell their hydrogen at a 10 year levelized cost of $\$ 7.06$ and $\$ 6.06$ per million Btu respectively. 
Table 4.4.1 E-Gas Co-Production Plant TPC in Thousands of Year 2005 Dollars

\begin{tabular}{|c|c|c|c|}
\hline Account \# & Account Title & Equip Trains & Equip Trains \\
\hline 1 & Coal \& Sorbent Handling & 32,369 & 32,369 \\
\hline 2 & Coal-Water Slurry Prep \& Feed & 40,909 & 40,909 \\
\hline 3 & Feedwater \& Misc BOP Systems & 19,766 & 19,766 \\
\hline 4 & Gasifier \& Accessories & 211,715 & 181,795 \\
\hline 5 & H2 Separation, Gas Cleanup, \& Piping & 91,051 & 91,051 \\
\hline 6 & Combustion Turbine \& Accessories & 58,099 & 58,099 \\
\hline 7 & HRSG, Ducting, \& Stack & 49,885 & 49,885 \\
\hline 8 & Steam Turbine Generator & 31,919 & 31,919 \\
\hline 9 & Cooling Water System & 13,922 & 13,922 \\
\hline 10 & Slag/Ash Handling Systems & 17,477 & 17,477 \\
\hline 11 & Accessory Electric Plant & 55,916 & 55,096 \\
\hline 12 & Instrumentation \& Control & 26,193 & 26,193 \\
\hline 13 & Improvements to Site & 10,720 & 10,720 \\
\hline 14 & Buildings \& Structures & 18,559 & 18,559 \\
\hline & Total & 678,500 & 647,760 \\
\hline
\end{tabular}


Table 4.4.2 E-Gas Plant Operating and Consumables Requirements

\begin{tabular}{|c|c|c|c|c|}
\hline \multicolumn{5}{|c|}{ OPERATING REQUIREMENTS } \\
\hline & & & WMM & $1 / 21 / 06$ \\
\hline \multicolumn{5}{|l|}{$\mathrm{H} 2$ \& Electric Coproduction -E-Gas IGCC } \\
\hline Operating Labor Rate(base) & $\$ 2800$ & ) ner hour & & \\
\hline Operating Labor Burden & $35 \%$ & of base & & \\
\hline Labor Overhead Charge Rate & $30 \%$ & of base & & \\
\hline Operating Labor Hours per Year & 1.944 & & & \\
\hline Administrative \& Support Labor & $45.15 \%$ & \multicolumn{2}{|c|}{ of Operating Labor } & \\
\hline \multirow{2}{*}{\multicolumn{5}{|c|}{ Operating Labor Requirements (OJ) per Shift - 4 Shifts }} \\
\hline & & & & \\
\hline Category & \multicolumn{2}{|c|}{1 Unit per Mod } & \multicolumn{2}{|c|}{ Total Plant } \\
\hline Skilled Operator & \multirow{2}{*}{\multicolumn{2}{|c|}{$\frac{3}{18}$}} & \multicolumn{2}{|c|}{3} \\
\hline Operator & & & & \\
\hline Foreman & \multicolumn{2}{|c|}{3} & \multicolumn{2}{|c|}{$\frac{10}{3}$} \\
\hline Lab Techs, etc & \multicolumn{2}{|c|}{2} & \multicolumn{2}{|c|}{2} \\
\hline Total OJs & \multicolumn{2}{|c|}{26} & \multicolumn{2}{|c|}{26} \\
\hline \multicolumn{5}{|c|}{ CONSUMABLES } \\
\hline \multicolumn{5}{|c|}{ H2 \& Electric Coproduction -E-Gas IGCC } \\
\hline & \multicolumn{2}{|c|}{ Consumption } & \multicolumn{2}{|c|}{ Unit } \\
\hline & Initial & Per Day & \multirow{2}{*}{\multicolumn{2}{|c|}{$\frac{\text { Cost }}{\$ 08 ?}$}} \\
\hline Water (per 1,000gals) & $\mathrm{N} / \mathrm{A}$ & 2,917 & & \\
\hline \multicolumn{5}{|l|}{ Chemicals } \\
\hline Water Treatment (lbs) & 211,845 & 7,061 & \multicolumn{2}{|c|}{$\$ 0.20$} \\
\hline Limestone (Tons) & 0 & 0 & \multicolumn{2}{|c|}{$\$ 18.00$} \\
\hline cos Catalyst (CuFt) & 340 & 0.31 & \multicolumn{2}{|c|}{$\$ 575.00$} \\
\hline Shift Catalvst (CuFt) & 757 & 1.30 & \multicolumn{2}{|c|}{$\$ 450.00$} \\
\hline Claus Catalyst (CuFt) & 1.070 & 1.47 & \multicolumn{2}{|c|}{$\$ 325.00$} \\
\hline Hydrogenation Catalyst (CuFt) & 290 & 0.40 & \multicolumn{2}{|c|}{$\$ 290.00$} \\
\hline Amine (lbs) & 6.480 & 216 & & \\
\hline Ammonia (lbs) & 0 & 0 & & \\
\hline Other & & & & \\
\hline Supplemental Fuel (MMbtu) & $\mathrm{N} / \mathrm{A}$ & 0 & & \\
\hline Waste Disposal & & & & \\
\hline Ash (Tons) & $\mathrm{N} / \mathrm{A}$ & 0 & & \\
\hline Slag (Tons) & $\mathrm{N} / \mathrm{A}$ & 455 & & \\
\hline BYPRC & DUCTS & & & \\
\hline Excess Electric Generation (MWh) & $\mathrm{N} / \mathrm{A}$ & 6.046 & & \\
\hline Sulfur (Tons) & $\mathrm{N} / \mathrm{A}$ & 127 & & \\
\hline & $\overline{E L}$ & & & \\
\hline Fuel - Coal (Tons) & 66,409 & 4,427 & & \\
\hline & & & & \\
\hline
\end{tabular}


Table 4.4.3 E-Gas Plant Operating and Consumables Costs

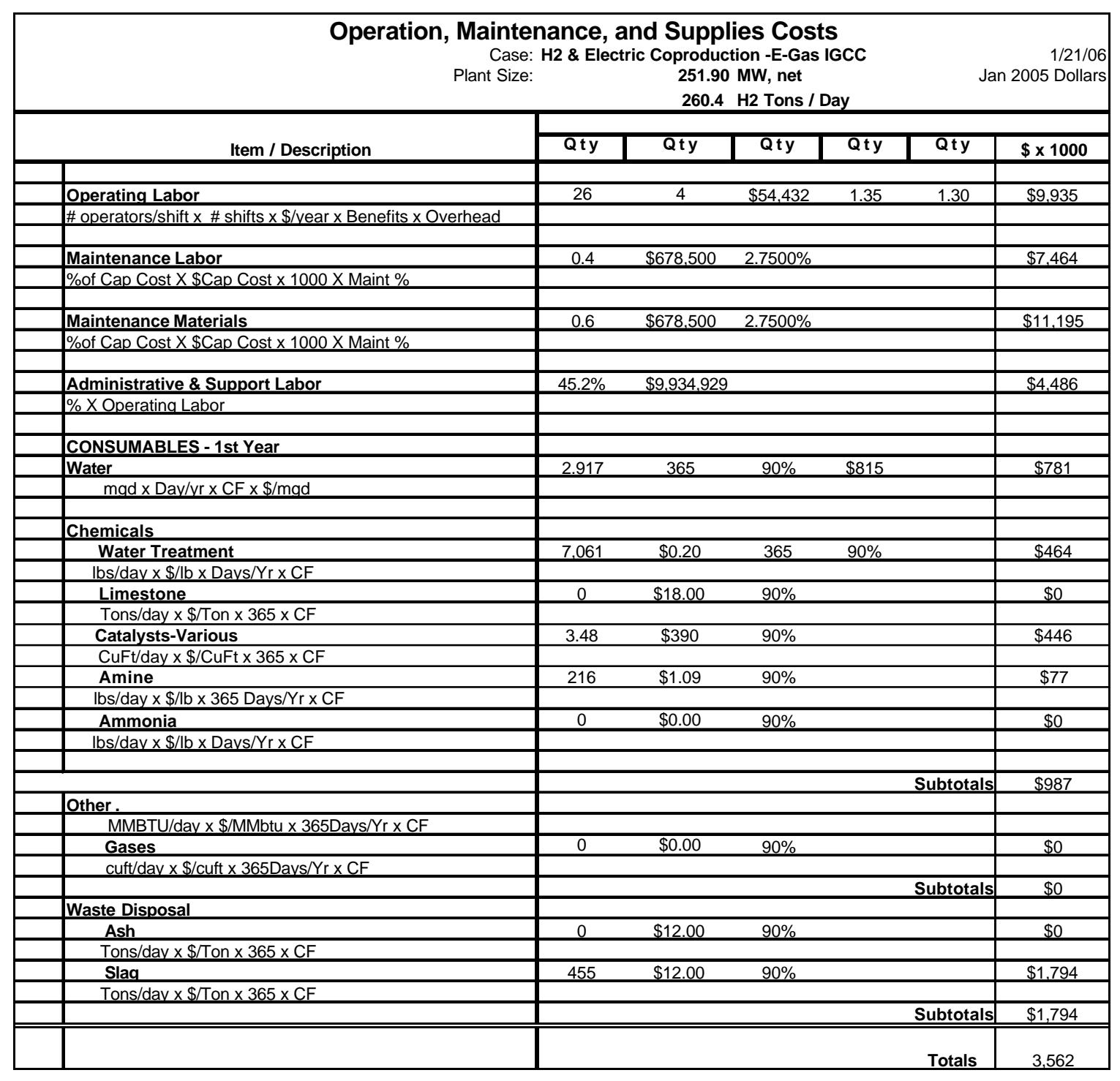


Table 4.4.4 E-Gas Plant Hydrogen Production Cost (3 Train Plant)

CAPITALINVESTMENT \& REVENUE REOUIREMENT SUMMARY

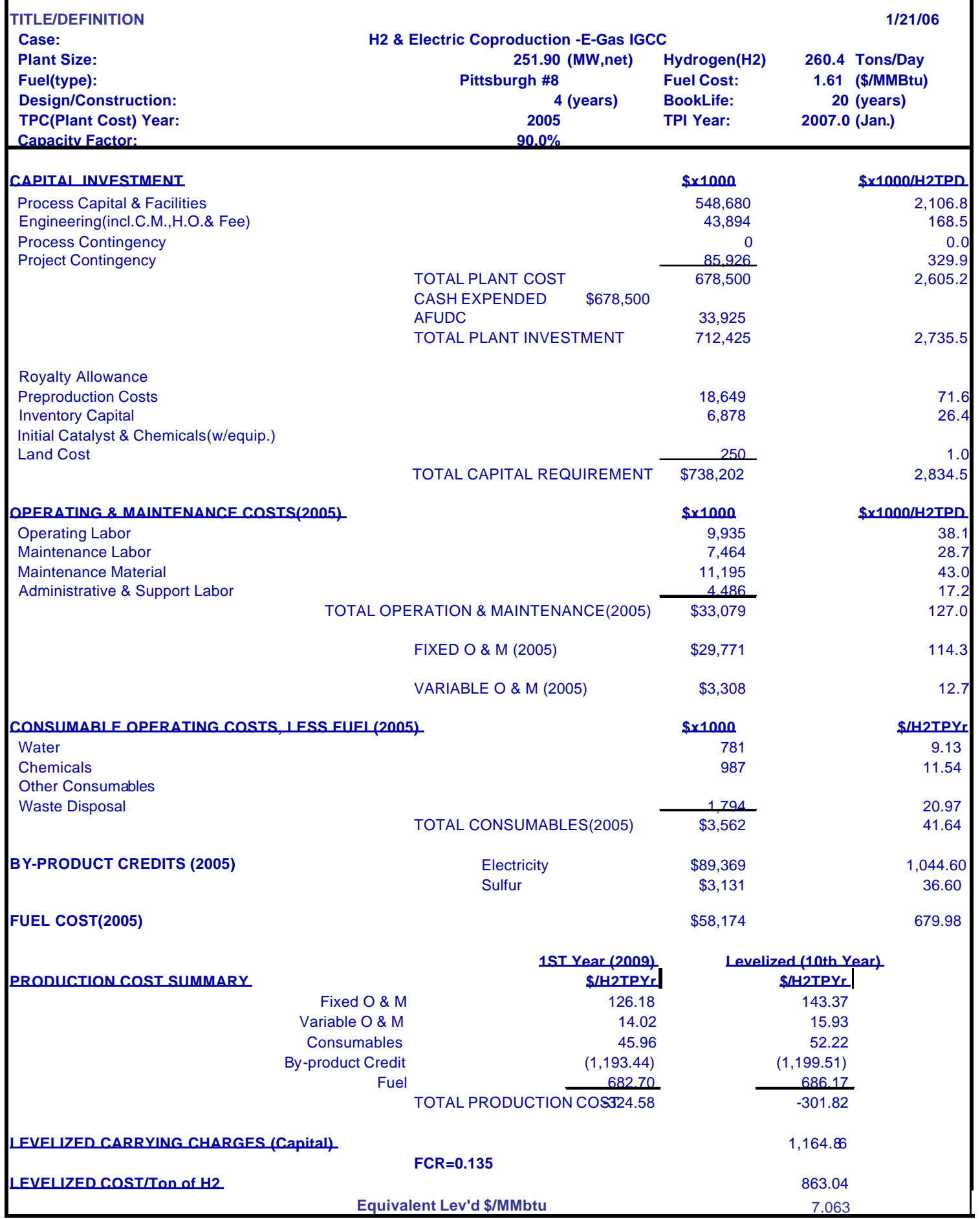


Table 4.4.5 E-Gas Plant Hydrogen Production Cost (2 Train Plant)

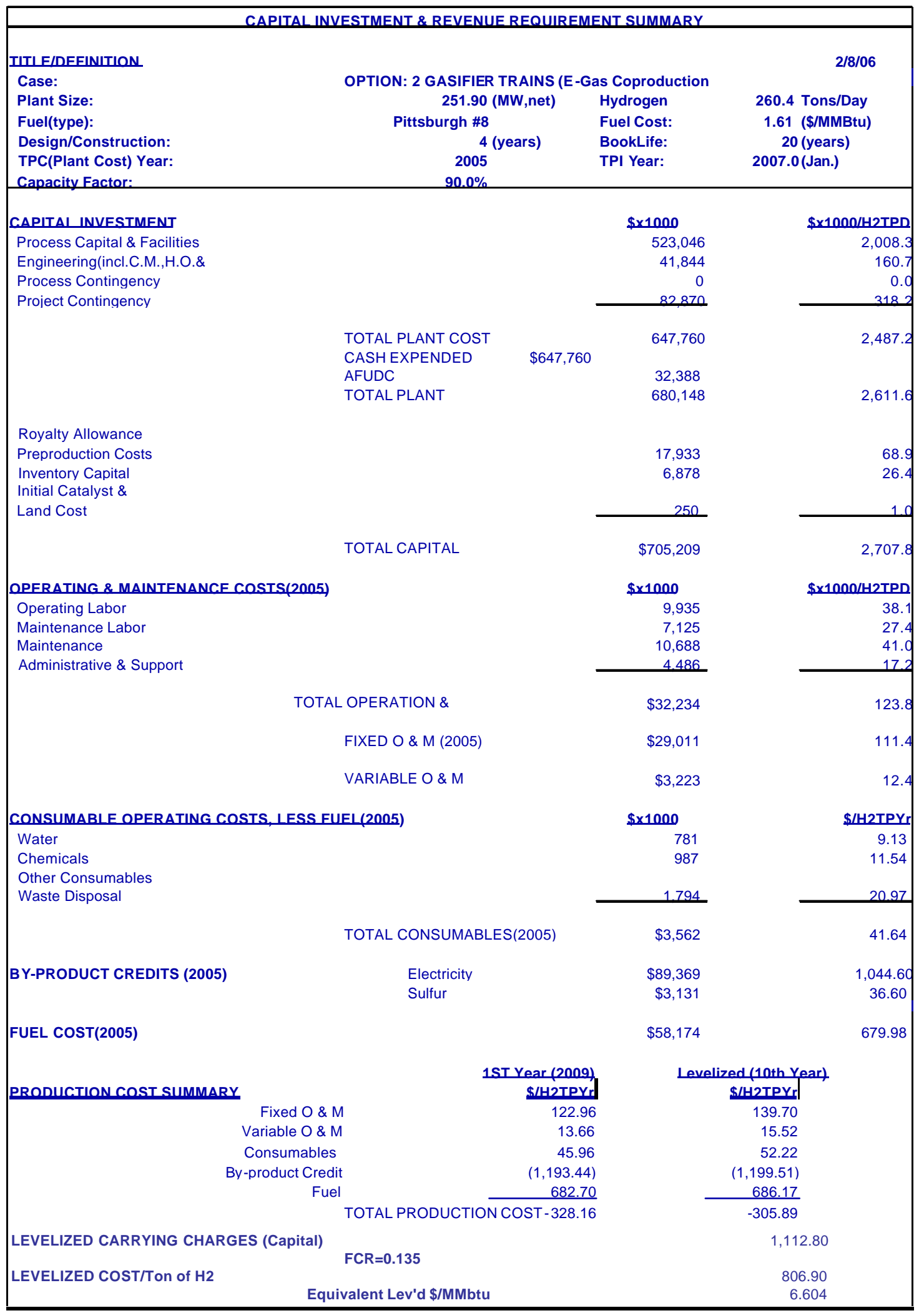


Table 4.4.6 E-Gas Plant Economic Summary

E-Gas Co-Production Plant Economic Summary (Year 2005 Dollars)

Number of Gasification Equipment Trains

$3^{*} \quad 2$

Plant Capacity Factor, \%

$90 \quad 90$

Net Power Output, MWe

$251.9 \quad 251.9$

Hydrogen Production Rate, lb/hr

$21,703 \quad 21,703$

Total Plant Cost, \$MM

$678.5 \quad 647.8$

Total Plant Investment, \$MM

$712.4 \quad 680.1$

Total Capital Requirement, \$MM

$738.2 \quad 705.2$

1st Year Operating \& Maintenance Cost, \$MM

$33.1 \quad 32.2$

1st Year Consumables Cost less Fuel, \$MM

$3.6 \quad 3.6$

1st Year Byproduct Credit, $\$ M M$

Electricity

$89.4 \quad 89.4$

Sulfur

3.1

3.1

1st Year Fuel Cost, $\$ M M$

$58.2 \quad 58.2$

Levelized Cost of Hydrogen, \$/MMBtu

7.063

6.604

*Includes One Spare Train 


\subsection{PCFB Gasifier Based Co-Production Plant}

\subsection{Plant Overview, Performance, and Emissions}

\section{Overview}

The PCFB based co-production plant is shown in Figure 5.1.1. The plant consists of two sections; the first is dedicated to the production of hydrogen and incorporates a gasification equipment module, whereas, the second section is dedicated to electric power generation and incorporates a conventional CFB boiler. The heart of the gasification equipment module is an oxygen blown, PCFB gasifier that consists of a riser, a recycle cyclone, and a dipleg that returns circulating solids to the base of the riser. From a feeding standpoint the PCFB gasifier is versatile; it operates equally well with a 35 weight percent coal - 65 weight percent water slurry feed, a 75 percent coal - 25 percent water paste feed, or dry feed (in the latter, the coal is pressurized in lock hoppers and blown into the gasifier). Since an investigation to determine the most economical feed arrangement was beyond the scope of this study, and, to assure a consistent comparison of the two plants, it was decided to operate the PCFB gasifier with the same slurry feed, the same oxygen feed, and the same syngas processing arrangement used by the Section 4 entrained flow coproduction plant.

Operating at 438.9 psia with a 35 percent coal - 65 percent water slurry, oxygen from a conventional, cryogenic air separation unit, and steam, the PCFB gasifier produces a $1900^{\circ} \mathrm{F}$, medium Btu, coal derived syngas and a granular, non sticky char residue. The syngas is cooled to $650^{\circ} \mathrm{F}$ in a fire-tube type boiler that generates $503^{\circ} \mathrm{F} 700$ psia steam. The steam proceeds to the $\mathrm{CFB}$ boiler for heating to $1005^{\circ} \mathrm{F}$ (becomes part of steam turbine reheat steam) and the cooled syngas is then stripped of particulate by a pre-cleaner cyclone and candle filter. After exiting the filter, steam is injected into the syngas to yield a 1.75 steam to CO molar ratio to support downstream water gas shift reactions. The humidified syngas passes through three stages of water gas shift reactors (two high temperature and one low temperature) and gas coolers and the syngas is delivered to a PSA system at $90^{\circ} \mathrm{F}$; the PSA separates the hydrogen from the syngas delivering it with a purity of 99.95 percent at a rate of $261 \mathrm{tpd}$ at 355 psig for sale to a near by refinery.

Condensate formed during the cooling of the syngas to $90^{\circ} \mathrm{F}$ contains contaminants, i.e., $\mathrm{HCN}$, $\mathrm{NH}_{3}, \mathrm{HCl}$, etc. and this "gray water" is sent to a central water treatment system; after cleaning, the water is supplied to the slurry preparation system and the stripping off-gas is sent to the CFB boiler.

The char collected by the cyclone and candle filter and the char drained from the bottom of the gasifier are depressured and transported to the CFB boiler using the PSA vent/purge gas. The char lock hoppers are pressurized with syngas and, when depressuring, they also vent their gases to the CFB boiler. 


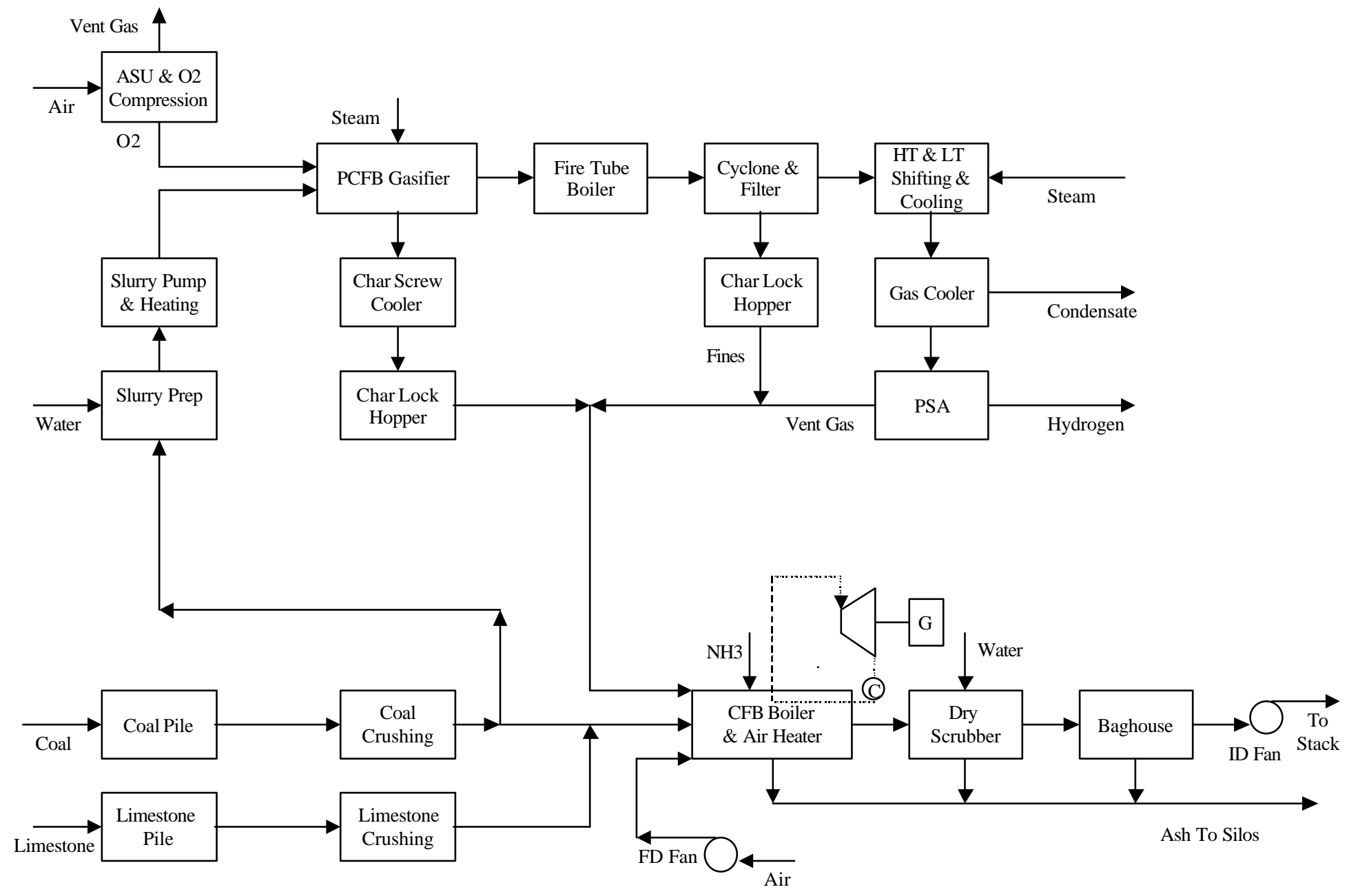

Figure 5.1.1. PCFB Gasifier Plant Process Block Diagram 
The heart of the power producing section of the plant is a conventional CFB boiler consisting of a riser/furnace section, recycle cyclones, diplegs, loop seals, and heat transfer surfaces; it is followed by an air heater, dry scrubber, and baghouse filter and incorporates forced draft and induced draft fans. Crushed coal and the char-PSA vent gas stream from the hydrogen leg of the plant fuel the CFB boiler and limestone is injected to control $\mathrm{SO}_{2}$ emissions; to control NOx emissions, the combustion air is admitted to the CFB boiler in stages and ammonia is injected into the flue gas for the selective non-catalytic reduction of NOx (SNCR). A portion of the limestone, calcined in and drained from the CFB system, provides additional sulfur capture in the spray dryer scrubber. The CFB boiler produces steam for process use and to drive a 307.7 MWe steam turbine. The steam turbine power is sold to the grid to provide a revenue stream that reduces the hydrogen sell price. In the event the gasification leg of the plant should be out of service, the CFB boiler can be operated totally on coal to maintain its full load revenue stream.

\section{Performance}

Figures 5.1.2 and 5.1.3 identify the flow rates, pressures, and temperatures of the plant's air/gas flow paths. Tables 5.1.1 and 5.1.2 summarize the plant performance and identify its parasitic power loads; the plant operates with an effective thermal efficiency of 53.0 percent, consumes coal at the total rate of $333,327 \mathrm{lb} / \mathrm{hr}$ ( 70 percent to the PCFB gasifier and 30 percent to the CFB boiler) and produces 261tpd of hydrogen and 255.5 MWe of electricity. 


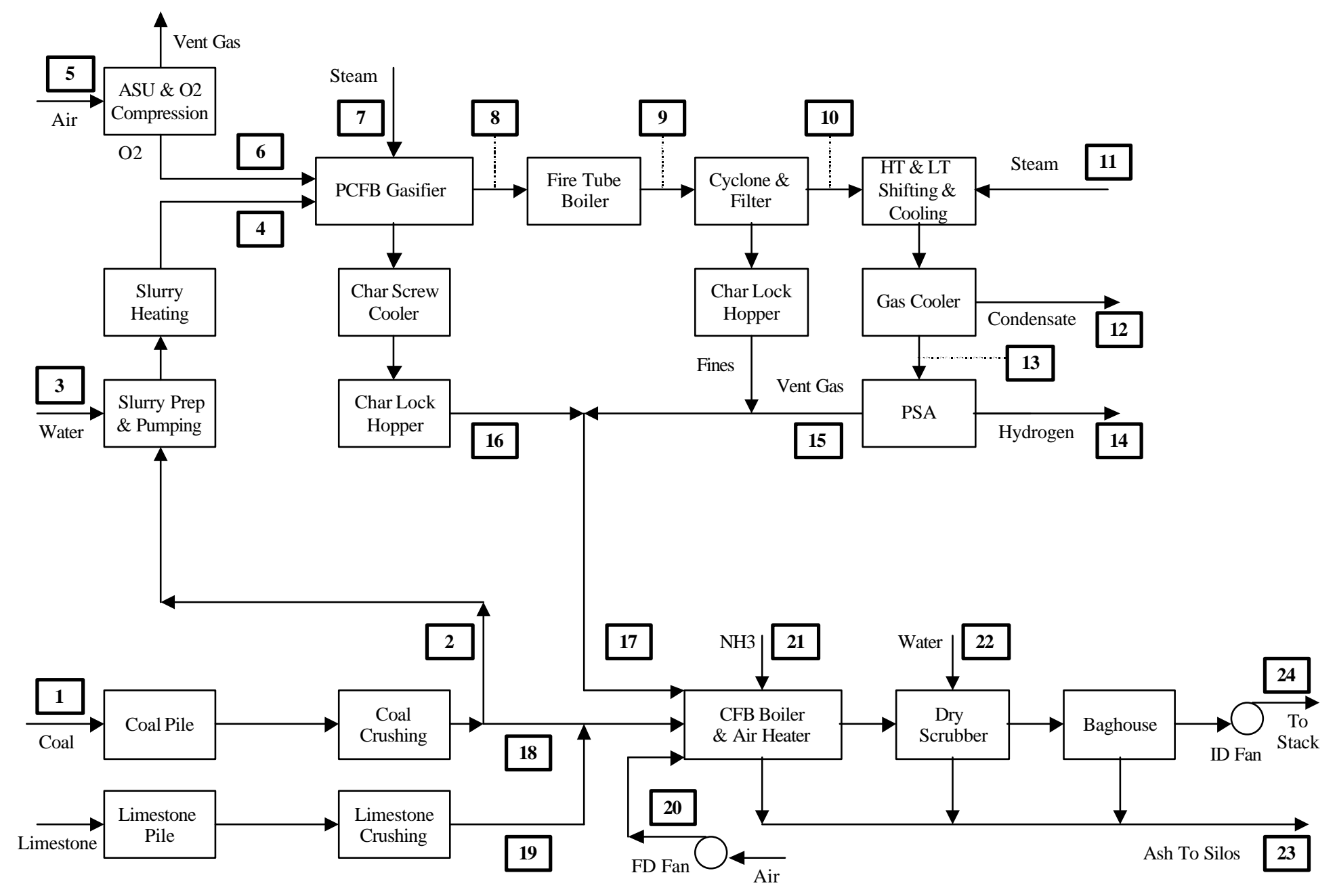

Figure 5.1.2 PCFB Gasifier Plant Flow Stream Locations 


\begin{tabular}{|c|c|c|c|c|c|c|c|c|c|}
\hline Stream Number & & 1 & 2 & 3 & 4 & 5 & 6 & 7 & 8 \\
\hline Stream Location & & Coal Pile & Slurry Prep & Slurry Prep & Gasifier & ASU & Gasifier & Gasifier & Gasifier \\
\hline Temperature, F & & 59 & 59 & 59 & 250 & 59 & 212 & 633 & 1900 \\
\hline Pressure, psi & & 14.7 & 14.7 & 14.7 & 444.9 & 14.7 & 454.9 & 648.5 & 438.9 \\
\hline \multirow{4}{*}{$\begin{array}{l}\text { Medium } \\
\text { Flow Rate, Klb/hr }\end{array}$} & & coal & coal & water & slurry & air & $\mathrm{O} 2$ & steam & mixture \\
\hline & Gas & & & & & 638.540 & 144.080 & 45.000 & 468.941 \\
\hline & Solids & 333.327 & 232.600 & & 232.600 & & & & 45.212 \\
\hline & Liquid & & & 103.775 & 103.775 & & & & \\
\hline Total Flow, Klb/hr & & 333.327 & 232.600 & 103.775 & 336.375 & 638.540 & 144.080 & 45.000 & 514.153 \\
\hline Stream Number & & 9 & 10 & 11 & 12 & 13 & 14 & 15 & 16 \\
\hline Stream Location & & Cooler Outlet & Filter Outlet & HT Shift Inlet & Drains & PSA Inlet & PSA Outlet & PSA Outlet & Gasifier \\
\hline Temperature, F & & 650 & 650 & 455 & 90 & 90 & 90 & 90 & 650 \\
\hline Pressure, psi & & 435.9 & 428.4 & 440.0 & 379.9 & 379.9 & 369.9 & 20.0 & 17.0 \\
\hline Medium & & mixture & syngas & steam & condensate & syngas & $\mathrm{H} 2$ & PSA vent & char \\
\hline \multirow[t]{3}{*}{ Flow Rate, Klb/hr } & Gas & 468941 & 468941 & 117559 & & 487686 & 21753 & 465934 & \\
\hline & Solids & 45.212 & & & & & & & 11.311 \\
\hline & Liquid & & & & 98.814 & & & & \\
\hline Total Flow, Klb/hr & & 514.153 & 468.941 & 117.559 & 98.814 & 487.686 & 21.753 & 465.934 & 11.311 \\
\hline Stream Number & & 17 & 18 & 19 & 20 & 21 & 22 & 23 & 24 \\
\hline Stream Location & & CFB Inlet & CFB Inlet & CFB Inlet & CFB Inlet & CFB & Scrubber & Ash Silo & Stack \\
\hline Temperature, F & & 148 & 59 & 59 & 59 & 59 & 59 & 148 & 173 \\
\hline Pressure, psi & & 17.0 & 14.7 & 14.7 & 14.7 & 14.7 & 14.7 & 14.7 & 14.7 \\
\hline Medium & & mixture & coal & limestone & air & NH3 & water & ash & flue gas \\
\hline \multirow[t]{4}{*}{ Flow Rate, $\mathrm{Klb} / \mathrm{hr}$} & & & & & & & & & \\
\hline & Gas & 465.934 & & & 2270.000 & 0.085 & & & 2954.750 \\
\hline & Solids & 56.515 & 100.727 & 64.922 & & & & 98.544 & \\
\hline & Liquid & & & & & & 95.000 & & \\
\hline Total Flow, Klb/hr & & 522.449 & 100.727 & 64.922 & 2270.000 & 0.085 & 95.000 & 98.544 & 2954.750 \\
\hline
\end{tabular}

Figure 5.1.3 PCFB Gasifier Plant Flow Stream Operating Conditions 
Table 5.1.1 PCFB Gasifier Plant Performance Summary

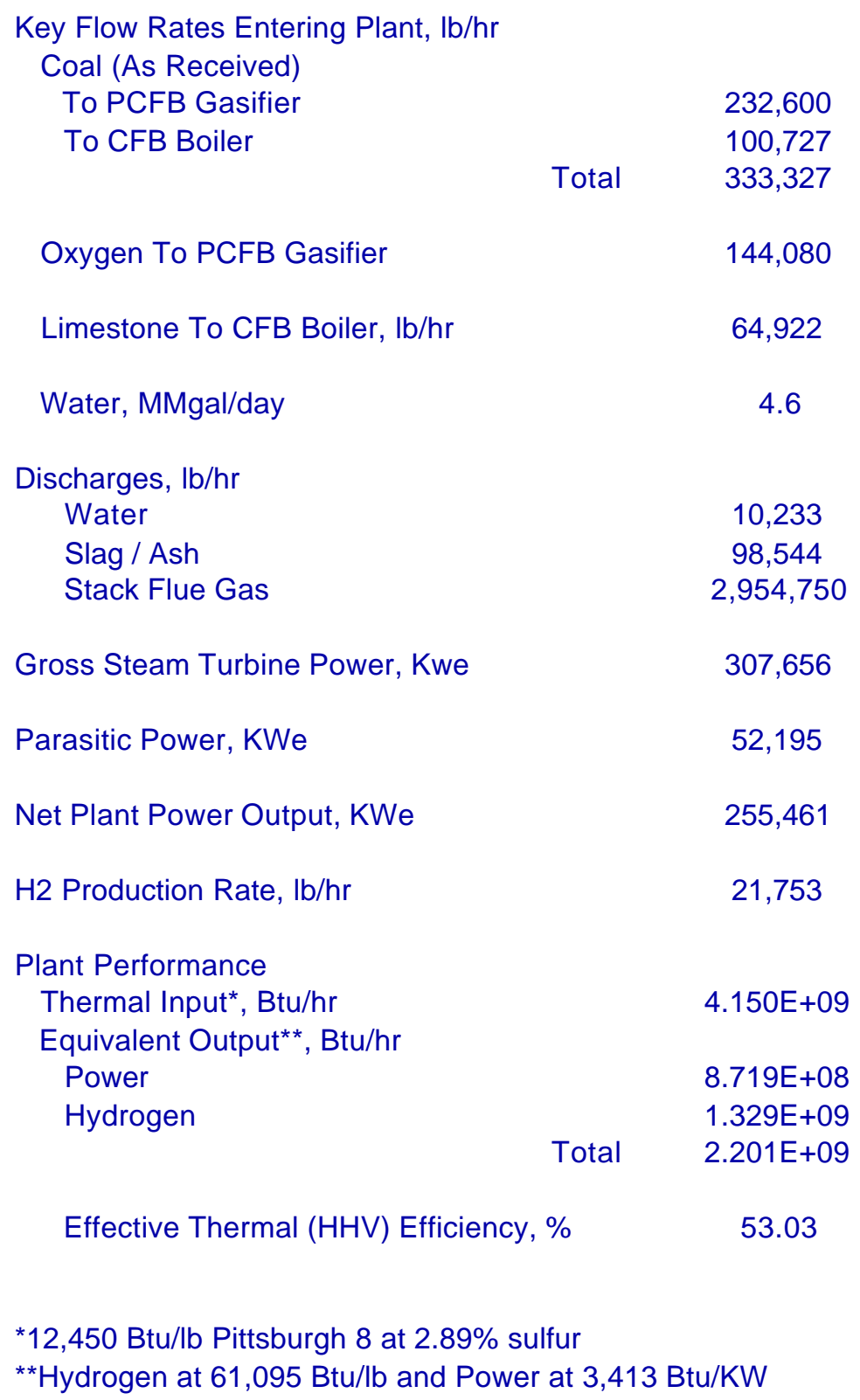


Coal/Limestone Handling

Gasifier Coal Milling

CFB Coal Crushing

CFB Limestone Crushing**

Coal Slurry Pumps
Totals*

490

595

40

215

Air Separation Unit Auxiliaries

15,400

Oxygen Compressor

7,060

22,460

CFB Primary Air Fan

2,865

CFB Spray Dryer Scrubber

1,100

400

CFB Boiler/Scrubber Ash Transport to Silos

5,720

650

10,735

Condensate Pump

HP Boiler Feedwater Pump

LP Boiler Feedwater Pump

7,815

275

3,610

Circulating Water Pump

2,090

14,360

Steam Turbine Auxiliaries

400

Transformer Losses

900

1,300

Miscellaneous Balance-of-Plant

2,000

2,000

Totals $\quad 52,195 \quad 52,195$

* Totals by Process Area

**Limestone Crushing and Feeding in CFB Balance 


\section{Emissions}

In the PCFB gasifier based plant all the gases that discharge to the plant stack emanate from the $\mathrm{CFB}$ boiler system, hence it controls the plant emissions. To control $\mathrm{SO}_{2}$ emissions, limestone is injected into the CFB boiler and recycled to a downstream spray dryer scrubber. To control NOx emissions, combustion air is injected into the CFB boiler in stages and ammonia is injected into its flue gas. To control particulate emissions, a baghouse filter is provided downstream of the scrubber. This same approach to emission control was utilized in the Jacksonville Electric Authority 300 MWe CFB Boiler Demonstration Project [5-1]; when operating with Pittsburgh No 8 coal, that CFB boiler system demonstrated 98.5 percent sulfur capture. This capture efficiency together with the pound per million Btu emission rates observed for $\mathrm{NOx}, \mathrm{CO}$, and particulate were used to establish the co-production plant emissions on a pound per hour basis. Since the CFB boiler heat release is approximately 60 percent of the total plant heat input, these values were then expressed on a total plant heat input basis yielding the values shown in Table 5.1.3.

Table 5.1.3 PCFB Gasifier Plant Emissions

\begin{tabular}{|c|c|}
\hline \multicolumn{2}{|l|}{ SO2 } \\
\hline \% Capture & 98.5 \\
\hline $\mathrm{lb} / \mathrm{hr}$ & 289 \\
\hline Ib/MMBtu & 0.070 \\
\hline \multicolumn{2}{|l|}{ NOx } \\
\hline $\mathrm{lb} / \mathrm{hr}$ & 197 \\
\hline Ib/MMBtu & 0.048 \\
\hline \multicolumn{2}{|l|}{$\mathrm{CO}$} \\
\hline $\mathrm{lb} / \mathrm{hr}$ & 45.1 \\
\hline Ib/MMBtu & 0.011 \\
\hline \multicolumn{2}{|l|}{ Particulate } \\
\hline $\begin{array}{r}\mathrm{lb} / \mathrm{hr} \\
\end{array}$ & 16.6 \\
\hline lb/MMBtu & 0.004 \\
\hline
\end{tabular}

\subsection{Process and System Description}

The PCFB gasifier based plant consists of numerous systems that work together to produce hydrogen and electricity. For cost estimating purposes those systems have been divided into 14 processing blocks or cost accounts that are identical to those of the entrained flow gasifier based plant. The 14 accounts are presented in Appendix $\mathrm{C}$ and, in addition to facilitating cost estimating, these accounts serve as a frame work for a detailed process description of the plant as follows:

Coal, Limestone, and Sand Receiving and Handling

The Pittsburgh No 8 coal is delivered to the site in a 6 inch by zero size; the equipment used to receive, unload, stack, reclaim, crush, and transfer the coal to silos is listed in Account 1. The coal 
handling equipment is essentially identical to that of the entrained flow gasifier plant excepting that crushing is to a minus $1 / 2$ inch size and the transfer conveyor is extended so that it can also supply coal to the CFB boiler silos which are included in Account 7.

Limestone in a 2 inch by zero size is also delivered to the site by train, unloaded by the above equipment, transferred to a separate pile, reclaimed, and transported by the above transfer conveyor to a limestone silo located at the CFB boiler and included in Account 7.

The PCFB gasifier and CFB boiler are started with a bed of sand. The sand is delivered to the site by a pneumatic transport truck that blows the sand into those units before they are started up. Once operating, the sand beds are gradually replaced by a circulating mixture of coal and char (PCFB gasifier) or coal, ash, and limestone (CFB boiler).

\section{Coal-Water Slurry Preparation and Feeding}

The PCFB gasifier and CFB boiler operate with two different coal feed systems that withdraw their coal from separate storage silos. The coal stored in the CFB silos is ready for feeding/requires no further processing, whereas, the PCFB gasifier coal must first be milled to a fine size, mixed with water to form a slurry, and pumped into the unit. The slurry preparation, pumping, and heating system used is, with the exception of a difference in capacity and lower gasifier operating pressure (438.9 versus 514.4 psia), identical to that of the entrained flow gasifier plant. Since the PCFB plant utilizes only one gasifier, however, only two trains of coal processing/feeding equipment is required and the $336,375 \mathrm{lb} / \mathrm{hr}$ slurry feed rate is about 37 percent less than that of the entrained flow plant.

The coal-water slurry preparation and feeding equipment is listed in Account 2. Slurry preparation equipment consists of two 100 percent capacity trains of day silos, rod mills, and slurry product tanks that operate in parallel, crush minus 1/2 inch coal to a minus 200 mesh size, and mix it with water to form a 35 weight percent coal - 65 weight percent water slurry. From the product tanks the slurry is pumped to two 100 percent capacity feed trains, each connected to the single PCB gasifier and consisting of a slurry storage feed tank, slurry pumps, and slurry heaters. Each feed train normally operates at 50 percent capacity delivering slurry at the rate of $168,188 \mathrm{lb} / \mathrm{hr}$ at $250^{\circ} \mathrm{F}$.

The coal delivered to the CFB boiler silos requires no further processing and after passing through gravimetric feeders, drag chain conveyors, and isolation valves is gravity fed to the unit via chutes with an air assist.

\section{Oxygen and Nitrogen Supply Systems}

The PCFB gasifier oxygen supply system is, excepting for a difference in capacity and pressure, identical to that of the entrained flow gasifier plant. Since the PCFB plant utilizes only one gasifier, its oxygen flow rate is slightly less than half that of the entrained flow plant and only one train of equipment is required. The system incorporates an electrically driven compressor that supplies $210^{\circ} \mathrm{F} 70$ psia air to a conventional cryogenic ASU. The ASU includes a liquid oxygen storage tank to guard against short term disruptions and supplies 95 percent pure oxygen at a rate of $144,080 \mathrm{lb} / \mathrm{hr}$ to an electrically driven boost compressor. The latter pressurizes the oxygen for delivery to the gasifier at a pressure of 454.9 psia. 
The equipment making up the oxygen supply system is listed in Account $4 \mathrm{~B}$.

PCFB Gasifier, Fire-Tube Boiler, and Particulate Removal

The PCFB gasifier together with its fire-tube boiler, pre-cleaner cyclone, candle filter, char depressuring, and char transfer systems are listed under Account 4A. The PCFB gasifier is an approximately 110 foot tall pressure vessel that is refractory lined to a 5 foot inside diameter. Coal is injected at the base of the unit as a coal-water slurry into a bed of $1900^{\circ} \mathrm{F}$ char. Air and steam enter below the slurry injection point and fluidize the char bed. As these constituents react, a hot syngas is produced which conveys the char vertically up through the vessel/reactor and into a recycle cyclone. Solids contained in the syngas are collected by the recycle cyclone and drain via a dipleg back to the dense bed at the bottom of the PCFB reactor. This recycle loop of hot solids acts as a thermal flywheel and promotes efficient solid-gas reactions.

The 65 per coal - 35 percent water slurry enters the unit at a rate of $336,375 \mathrm{lb} / \mathrm{hr}$ at $250^{\circ} \mathrm{F}$ along with $45,000 \mathrm{lb} / \mathrm{hr}$ of $633^{\circ} \mathrm{F}$ steam and $144,080 \mathrm{lb} / \mathrm{hr}$ of $212^{\circ} \mathrm{F}$ oxygen. Based on these flow rates and, allowing for vessel heat loss, the gasifier operates at $1900^{\circ} \mathrm{F}$ with a superficial gas velocity of $20 \mathrm{ft} / \mathrm{sec}$ and a discharge pressure of $438.9 \mathrm{psia}$. At these conditions syngas is produced at a rate of $468,941 \mathrm{lb} / \mathrm{hr}$ with a hydrogen content of approximately 32 mole percent, a hydrogen to carbon monoxide molar ratio of 1.16 , and a steam to carbon monoxide molar ratio of 0.75 .

Char is produced at a rate of $56,515 \mathrm{lb} / \mathrm{hr}$ along with the syngas and the char continuously circulates through the gasifier until it reaches a density and or size that allow it to escape the recycle cyclone. A nozzle is provided at the bottom of the gasifier to drain/empty bed material at shutdown; the drain is also used intermittently during normal operation to prevent any oversize material from accumulating in the bottom of the bed. The drain nozzle leads to a pressurized water-cooled screw that controls the bottom char/bed withdrawal rate, cools it to $500^{\circ} \mathrm{F}$, and discharges to a surge hopper and a lock hopper that depressure the material. A delumper below the lock hopper breaks up any oversize material that may have formed in the unit and a rotary valve feeds the material to a pipeline for transport to the CFB boiler with PSA vent gas.

The PCFB gasifier together with its recycle cyclone, fire-tube boiler, and bottom char cooling and depressuring system is shown in Figure 5.2.1. A surge hopper and lock hopper are also provided under the pre-cleaner cyclone and candle filter to depressure the char they collect. After depressuring the two char streams drain to a common day bin and a rotary valve feeds the material to a pipe line for transport to the CFB boiler with PSA vent gas.

Syngas for Hydrogen Production

After being stripped of all gas entrained particulate in the candle filter, the $650^{\circ} \mathrm{F}$ syngas undergoes steam injection. The injected steam increases the syngas steam to CO ratio to 1.75 and three stages of water gas shift reactors (two high temperature and one low temperature) with sulfur tolerant catalysts are provided that convert approximately 92 percent of the $\mathrm{CO}$ to $\mathrm{CO}_{2}$ (for a consistent comparison, the PCFB plant utilizes the same sulfur tolerant catalysts, performance, and conversion values as the entrained flow plant water gas shift reactors). Since the water gas shift reaction is exothermic, water-cooled heat exchangers are provided to control the syngas temperature and eventually cool it to $90^{\circ} \mathrm{F}$ for delivery to the PSA system at a rate of 487,686 
$\mathrm{lb} / \mathrm{hr}$. During the cooling of the syngas, a condensate is formed that contains some of the gas contaminants i.e. $\mathrm{H}_{2} \mathrm{~S}, \mathrm{NH}_{3}$, etc. This gray water is sent to a steam stripper where the contaminants are driven off, the cleaned water sent to the coal-water slurry preparation system, and the off gas piped to the CFB boiler where it is burned.

The water gas shifting, gas cooling, and condensate equipment are listed in Account 5A-1.

Despite condensation in the upstream gas coolers, some hydrogen sulfide will remain in the cooled syngas (see Table 5.2.1 for syngas compositions at several different plant locations). With the PSA being highly selective, it separates hydrogen from the syngas to a purity of 99.95 percent and delivers it at a rate of $21,753 \mathrm{lb} / \mathrm{hr}$ at 370 psia for transport to the near by refinery. The gas that vents from the PSA exits at 20 psia and is used to convey the char collected by the filter, precleaner cyclone, and bed drain system to the CFB boiler. Since the vent gas is burned in the CFB boiler system, where all plant emission control takes place, the plant does not require an acid gas removal system.

The PSA system appears under Account 5B-1 and, producing the same amount of hydrogen, is essentially identical to that of the entrained flow plant.

The composition of the syngas entering and exiting the hydrogen production equipment train, as well as interior points, is presented in Table 5.2.1.

CFB Boiler

Coal, char, PSA vent gas, and gray water off-gas are burned in the CFB boiler with hot air delivered by forced draft and induced draft fans. The solids and gases contain sulfur and nitrogen which, during their combustion at $1600^{\circ} \mathrm{F}$, can form $\mathrm{SO}_{2}$ and $\mathrm{NOx}$. To control $\mathrm{SO}_{2}$ emissions, limestone is fed to the CFB boiler and, to minimize NOx emissions, the air is introduced in stages and SNCR employed. The solids and air enter at the base of the unit, form a relatively dense fluidized bed of coal, char, ash, and limestone, and the resulting flue gas, together with entrained particulate, flow vertically up the unit. At the top, recycle cyclones clean the gas of coarse particulate and return them to the base of the unit via bubbling fluidized bed heat exchangers and pressure seals to establish a circulating bed of hot solids. 


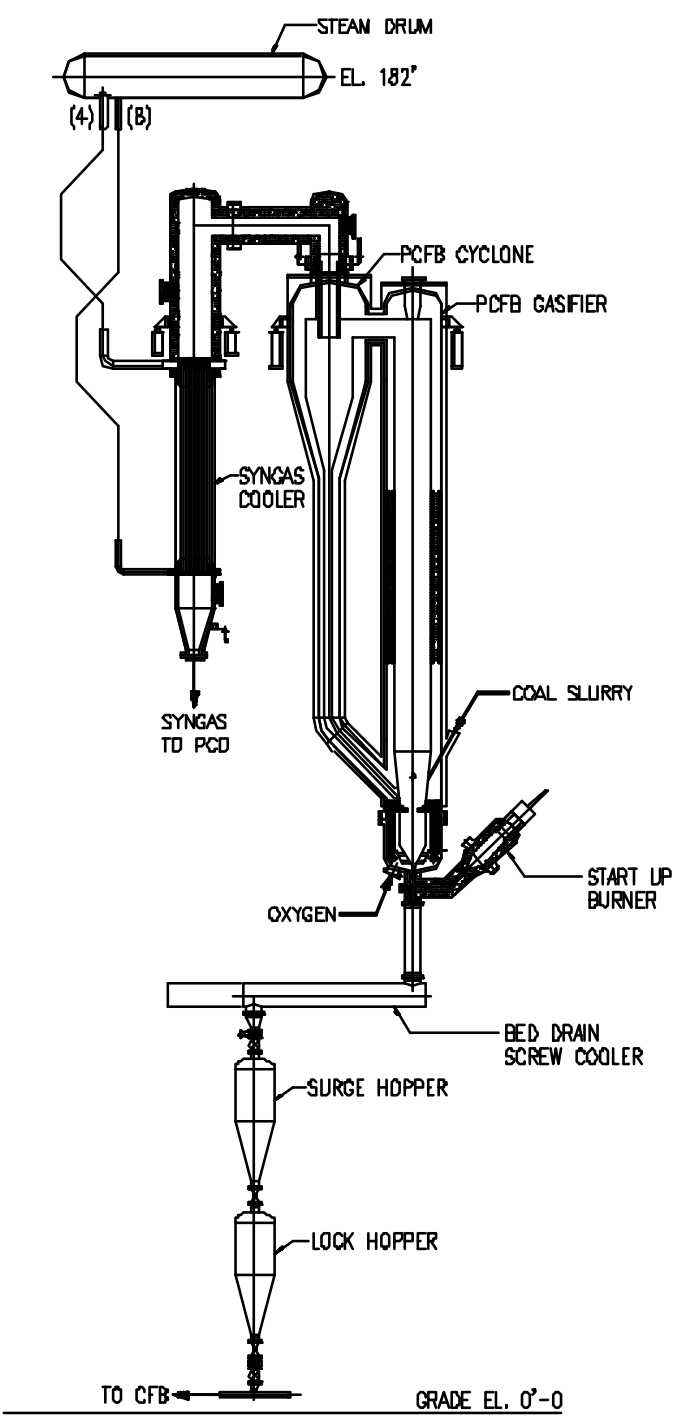

Figure 5.2.1 PCFB Gasifier Arrangement 
Table 5.2.1 PCFB Gasifier Syngas Compositions

\begin{tabular}{|c|c|c|c|c|c|}
\hline Location & & Filter Exit & $\begin{array}{c}\text { Inlet of HT } \\
\text { Shifter }\end{array}$ & $\begin{array}{c}\text { Outlet of LT } \\
\text { Shifter }\end{array}$ & PSA Inlet \\
\hline \multicolumn{6}{|l|}{ Gas } \\
\hline Temperature, F & & 650 & 587 & 419 & 90 \\
\hline Pressure, psia & & 428.4 & 427.4 & 389.9 & 379.9 \\
\hline \multicolumn{6}{|c|}{ Gas Composition, mole fraction } \\
\hline $\mathrm{AR}$ & & 0.0079 & 0.0062 & 0.0062 & 0.0076 \\
\hline $\mathrm{CH} 4$ & & 0.0332 & 0.0260 & 0.0260 & 0.0318 \\
\hline $\mathrm{CO}$ & & 0.2744 & 0.2152 & 0.0211 & 0.0258 \\
\hline $\mathrm{CO} 2$ & & 0.1481 & 0.1161 & 0.3101 & 0.3788 \\
\hline $\mathrm{H} 2$ & & 0.3188 & 0.2500 & 0.4440 & 0.5424 \\
\hline $\mathrm{H} 2 \mathrm{O}$ & & 0.2049 & 0.3765 & 0.1825 & 0.0016 \\
\hline $\mathrm{H} 2 \mathrm{~S}$ & & 0.0077 & 0.0060 & 0.0060 & 0.0074 \\
\hline $\mathrm{N} 2$ & & 0.0048 & 0.0037 & 0.0037 & 0.0046 \\
\hline \multirow[t]{2}{*}{ NH3 } & & 0.0003 & 0.0002 & 0.0002 & 0.0001 \\
\hline & Total & 1.0000 & 1.0000 & 1.0000 & 1.0000 \\
\hline Gas Molecular Weight & & 19.79 & 19.40 & 19.40 & 19.71 \\
\hline
\end{tabular}

A forced draft fan supplies air to a tubular air heater at a rate of 2,270,000 lb/hr where it is heated by hot exhaust flue gas to $543^{\circ} \mathrm{F}$ for delivery to the $\mathrm{CFB}$ boiler. In addition to the air, the major flow streams entering the CFB boiler are coal, char, limestone, and PSA vent gas at rates of $100,727 \mathrm{lb} / \mathrm{hr}, 56,515 \mathrm{lb} / \mathrm{hr}, 64,922 \mathrm{lb} / \mathrm{hr}$, and 465,934 lb/hr respectively; the CFB boiler combusts the fuels at $1600^{\circ} \mathrm{F}$ and their heat release is used to generate, superheat, and reheat steam to $1005^{\circ} \mathrm{F}$. The $2400 \mathrm{psig} 1005^{\circ} \mathrm{F}$ superheated steam is generated at a rate of $1,790,000 \mathrm{lb} / \mathrm{hr}$, whereas, the $569 \mathrm{psig} 1005^{\circ} \mathrm{F}$ reheat steam is provided at a rate of $1,848,000 \mathrm{lb} / \mathrm{hr}$. The reheat steam flow rate is slightly higher than the superheat flow rate because of the steam (cold reheat) generated by the PCFB gasifier fire-tube boiler. The distribution of the CFB boiler heat release is 51 percent from coal, 18 percent from char, and 31 percent from PSA vent gas. The CFB boiler operates with a combustion efficiency of 98 percent, a value typical of a conventional CFB boiler. In combusting the coal and char with limestone, an ash residue containing spent limestone is generated at the rate of $98,544 \mathrm{lb} / \mathrm{hr}$ for ultimate transfer to silos for disposal.

The CFB boiler is shown in Figures 5.2.2 and 5.2.3 together with its fuel and limestone silos. In plan view the assembly possesses a footprint approximately 160 foot wide by 220 foot long and the boiler consists of a single, water-cooled furnace, three steam cooled recycle cyclones, three Integrated Recycle Heat Exchangers (INTREXs ${ }^{\mathrm{TM}}$ ), and a parallel pass convective heat recovery section followed by an economizer and tubular air heater. The furnace is a gas tight enclosure formed from membrane tube panels that are cooled by the natural circulation of water from the 
steam drum. Water-cooled, partial division walls divide the furnace into three zones that help to evenly distribute gas and solids to the three recycle cyclone separators. Six furnace wing walls provide additional evaporative tube surface. To avoid erosion from circulating solids (coal, limestone, char, and ash) a thin refractory lining is applied over metal studs in the lower portion of the furnace and around the openings to the cyclones.

The three steam cooled cyclones are formed from membrane walls that are also protected from erosion by a 1 inch thick refractory lining. The hot solids collected by the cyclones pass through pressure seals and drain to the INTREX bubbling fluidized beds located beneath them and containing intermediate and finishing superheater tube bundles. These beds cool the solids for return to the furnace for reheating to $1600^{\circ} \mathrm{F}$. During start-up the cooling beds are bypassed and solids returned directly to the furnace.

The three cyclones discharge their $\sim 1600^{\circ} \mathrm{F}$ gas to a plenum that leads to two parallel gas paths. Each path contains convective tube bundles; one contains all reheat tube surfaces, the other contains primary superheat tube surface. Dampers located at the outlet of each path proportion the gas flow over their tube surfaces and enable reheat steam temperatures to be controlled without the need for water spray. The gas streams from the two paths combine for further cooling by convective economizer tube bundles and then discharge to a tubular air heater. The latter cools the flue gas from $641^{\circ} \mathrm{F}$ to $300^{\circ} \mathrm{F}$ and in doing so preheats the $\mathrm{CFB}$ combustion air to $543^{\circ} \mathrm{F}$.

After exiting the $\mathrm{CFB}$ boiler at $300^{\circ} \mathrm{F}$, the flue gas enters an $\mathrm{SO}_{2}$ polishing scrubber, exits at approximately $150^{\circ} \mathrm{F}$, proceeds to a bag house filter and induced draft fan, and discharges to the stack at $173^{\circ} \mathrm{F}$. The assembly is shown in Figure 5.2.4 and in plan view it possesses a footprint approximately 125 foot wide by 330 foot long. The scrubber is a semi-dry/spray dryer type unit that operates with processed CFB ash and slurry water and, together with the CFB boiler, enables the plant to operate with an overall sulfur capture efficiency of 98.5 percent. The CFB boiler $\mathrm{bed} / \mathrm{bottom}$ ash is cooled to $500^{\circ} \mathrm{F}$ via stripper coolers. A portion of that ash is crushed, mixed with ash captured by the bag house filter, slaked, slurried with water, and injected into the spray dryer to serve as its sulfur capturing sorbent; if necessary the recycled ash can be supplemented with a small amount of fresh lime. 


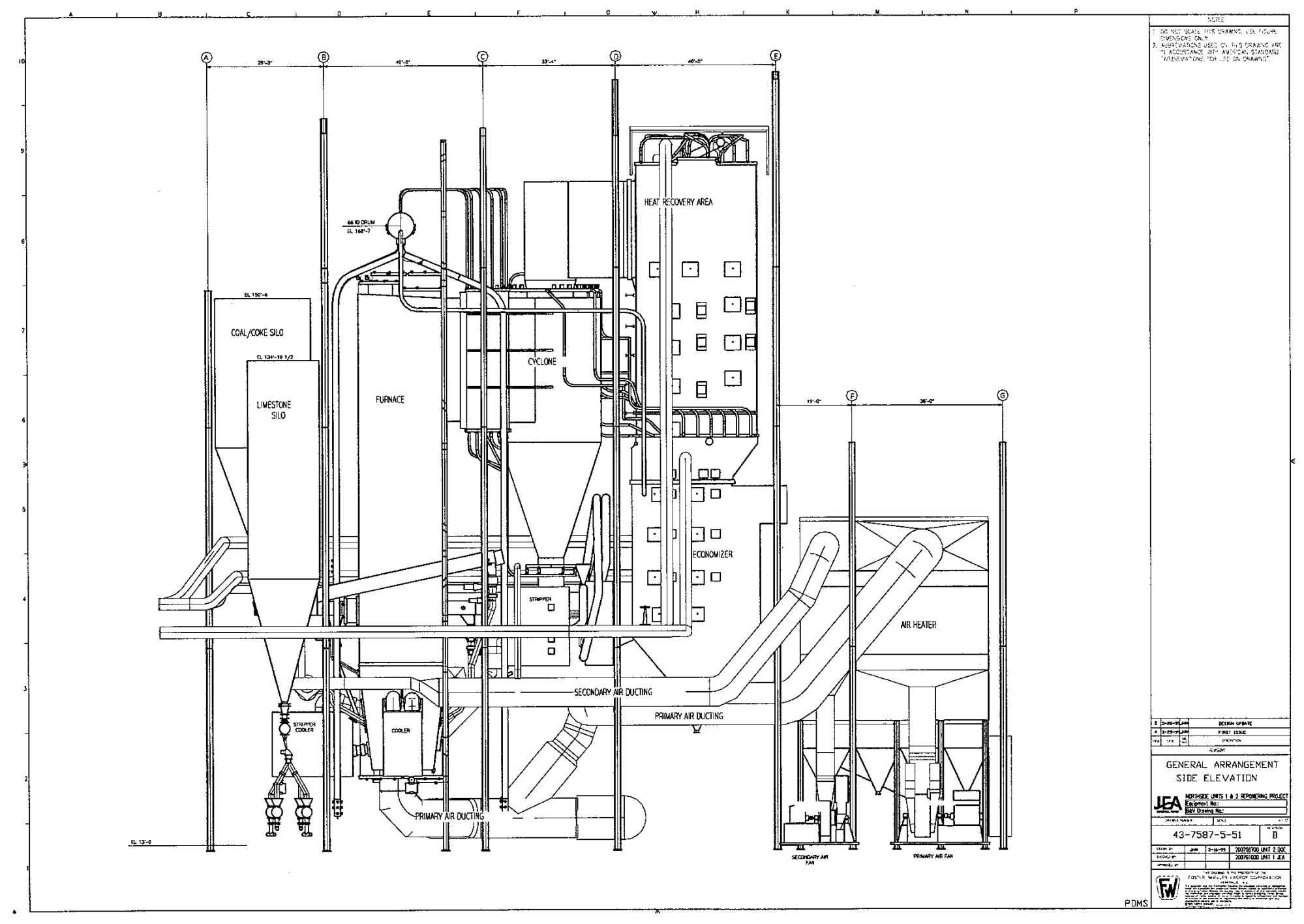

Figure 5.2.2 CFB Boiler Side View 


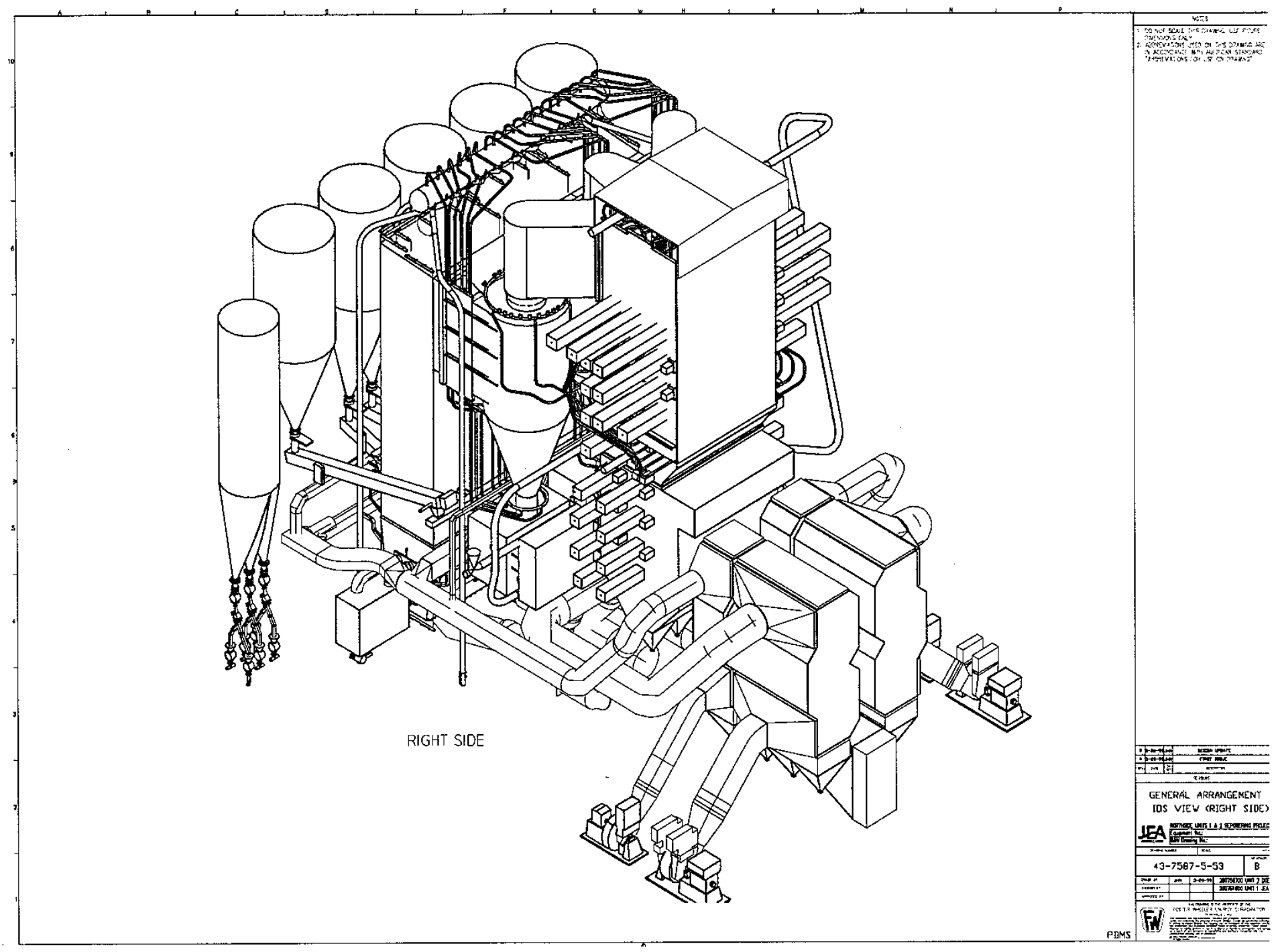

Figure 5.2.3 CFB Boiler Isometric View 


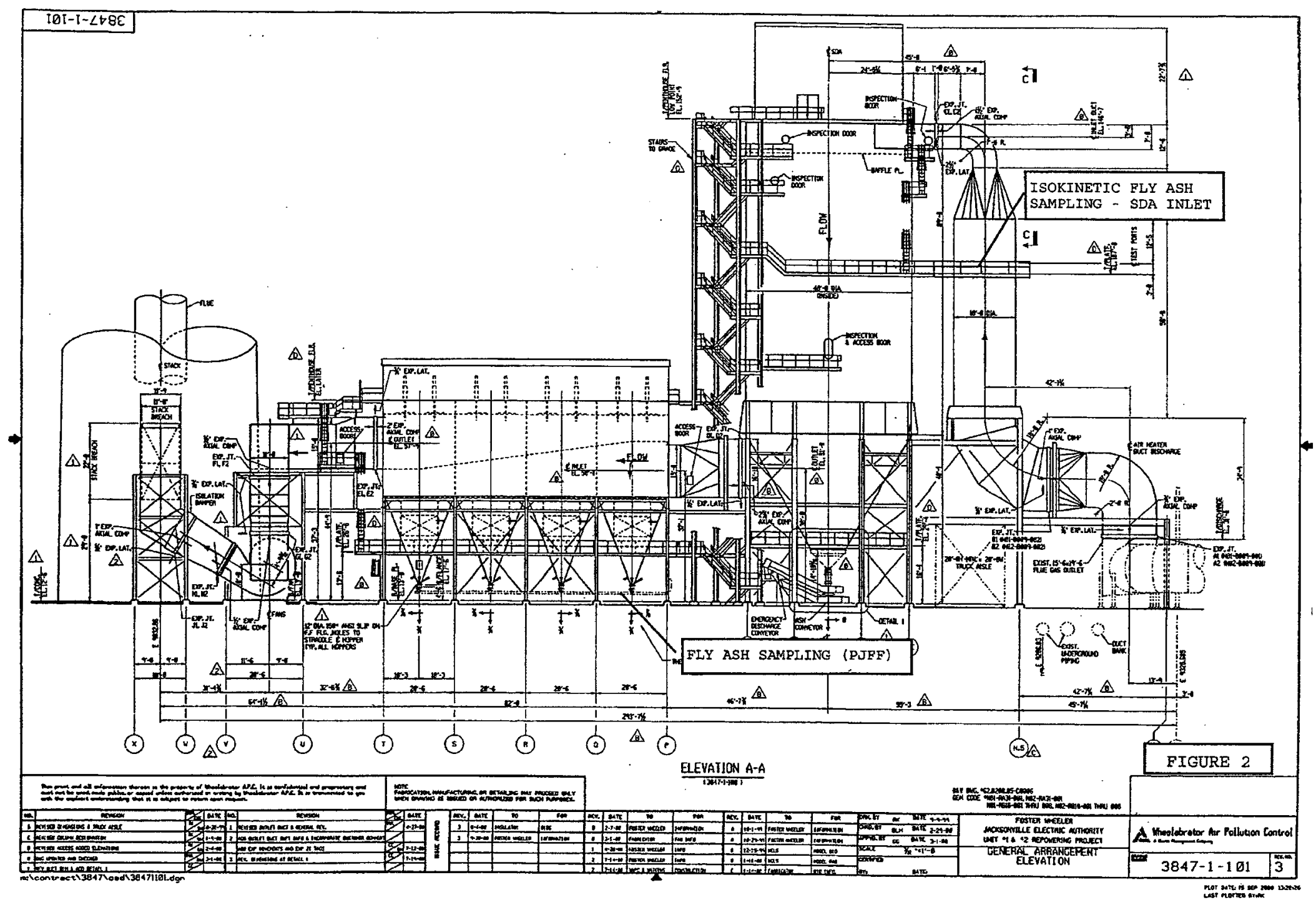

Figure 5.2.4 Spray Dryer Scrubber, Baghouse, ID Fan, and Stack Side View 
The CFB boiler together with its silos, feeders, fans, ash coolers, SNCR, air heater, spray dryer scrubber, bag house filter, structural steel, stack, and SNCR unloading, storage, and injection equipment are listed in Account 7.

\section{Steam Turbine Generator}

The steam turbine consists of tandem high pressure (HP), intermediate pressure (IP), and double flow low pressure (LP) turbine sections connected via a common shaft that drives a 3,600 RPM hydrogen-cooled generator. The turbine operates with $2400 \mathrm{psig} 1000^{\circ} \mathrm{F} 1,790,000 \mathrm{lb} / \mathrm{hr}$ throttle conditions, a single stage of reheat to $1000^{\circ} \mathrm{F}$, and 4 stages of steam extraction. The generator is a synchronous type that operates with an efficiency of 98 percent for a net output of $307.7 \mathrm{MWe}$.

A single pass, horizontal type condenser is provided under the steam turbine to condense the steam turbine exhaust at a rate of $1,490,000 \mathrm{lb} / \mathrm{hr}$ at 1 psia pressure.

The steam turbine and its auxiliaries are listed in Account 8.

$\underline{\text { Condensate and Feedwater Systems }}$

In the condenser the steam is indirectly cooled by circulating water that proceeds to a mechanical draft, evaporative cooling tower. The cooling tower consists of multiple cells that are operated as required to meet the plant cooling load; the cooling tower and circulating water pumps are listed under Account 9.

The condensate and feedwater equipment required by the plant are listed under Account 3 . The plant steam cycle is typical of a modern power generating plant; it employs a highly efficient regenerative feedwater heating system complete with pumps, deaerator, and 4 stages of feedwater heaters that deliver $491^{\circ} \mathrm{F}, 3010$ psig feedwater to the CFB boiler economizer at a rate of $1,709,000 \mathrm{lb} / \mathrm{hr}$. Where the cycle differs from a conventional unit is that it also delivers low pressure feedwater and steam to the gasification leg of the plant where the major users are:

1.) the PCFB gasifier fire-tube boiler---using $329^{\circ} \mathrm{F}$ feedwater, the fire-tube boiler cools the syngas from $1900^{\circ} \mathrm{F}$ to $650^{\circ} \mathrm{F}$ and in doing so generates $503^{\circ} \mathrm{F} 685$ psig saturated steam at a rate of $316,000 \mathrm{lb} / \mathrm{hr}$; approximately $1 / 3^{\text {rd }}$ of this steam is injected into the syngas for water gas shifting and the balance returns to the steam cycle.

2.) the PCFB gasifier----633F, 634 psig steam is injected into the gasifier at a rate of 45,000 $\mathrm{lb} / \mathrm{hr}$ to support steam carbon reactions.

Two 50 percent capacity motor driven pumps extract condensate from the condenser hot well and pump it through a feedwater heater and economizer and on to the deaerator. Two 50 percent capacity motor driven boiler feed pumps in turn pump the water through three additional stages of feedwater heaters, the CFB high pressure economizer, and deliver it to the CFB steam drum. 


\subsection{List of Plant Major Equipment}

The major pieces of equipment required by the PCFB gasifier based plant have been divided into the 14 accounts listed in Appendix C; those accounts are the basis for the plant costs presented in Section 5.4 and are identical to those of the entrained flow gasifier plant.

\subsection{Plant Costs and Economic Analysis}

The PCFB gasifier based co-production plant has been designed to produce the same amount of electricity and the same amount of hydrogen as the entrained flow gasifier plant. In addition, the PCFB gasifier based plant has been designed to use, wherever possible, similar gas processing equipment and similar balance of plant systems so that the differences between the two gasification technologies can be clearly seen. Aside from the PCFB gasifier and CFB boiler systems, which appear in Accounts 4 and 7, the two plants are similar and, as discussed in Section 3.5, the E-Gas based plant cost estimate was the starting point for the determination of the PCFB gasifier based plant costs. Starting with the former's cost estimate, Parsons modified its costs on an account by account basis to reflect changes to the PCFB gasifier based plant. As part of this effort FW provided Parsons with the arrangement, sizes and costs of the following equipment:

PCFB Gasifier Scope of Supply (Account 4)

Gasifier (riser, recycle cyclone, dipleg, and start up burners)

Fire-tube boiler with drum and piping

Gasifier to fire-tube boiler refractory lined piping

Bed drain char system (screw cooler, surge hopper, lock hopper, valving, delumper, and rotary valve)

Filter and pre-cleaner cyclone char system (surge hoppers, lock hoppers, valving, day bin, and rotary valves)

Instrumentation

CFB Boiler Scope of Supply (Account 7)

Boiler (riser, recycle cyclones, diplegs, INTREXs, heat recovery area, and start up burners)

Coal feed (silos, chutes, and feeders)

Limestone feed (silo, crushers, chutes, and feeders)

Bottom ash system (stripper coolers and rotary valves)

Air supply system (air ducting and Primary, Secondary, and ID fans)

Air heater

SNCR system (rail unloading, tanks, pumps, vaporizers, piping, and distribution system)

$\mathrm{SO}_{2}$ spray dryer scrubber system including bag house filter and flue gas ducting

Structural steel

Instrumentation

Using the size, arrangement, and cost data supplied by FW, Parsons estimated the cost of installing/erecting the above equipment together with the supply and erection of all other equipment required by the plant.

Tables 5.4.1 through 5.4.4 present the costs and economics determined by Parsons for the PCFB gasifier based co-production plant. Table 5.4.1 presents the costs of the plant at the account 
summary level and the reader is referred to Appendix $\mathrm{C}$ for sub-account values. Tables 5.4.2 and 5.4.3 present operating and consumable requirements and costs, respectively, and Table 5.4.4 calculates the plant 10 year levelized hydrogen production cost. Although the ash from the CFB boiler can potentially be used for road construction, structural fill, agricultural fertilizing, etc. the economics of such uses are highly site dependent and no credit was taken for this potential ash sale. In contrast, the electricity produced by the plant is assumed to be sold to the grid at a price of $\$ 45 / \mathrm{MWhr}$ and, based on a plant capacity factor of 90 per cent, its sale provides a revenue stream of $\$ 90.8$ million/yr. As seen in these tables the PCFB gasifier based plant has a total plant cost in year 2005 dollars of $\$ 625.4$ million and, allowing for a general inflation rate of 2.5 percent per year and coal cost escalating at only 0.1 percent per year, a 10 year levelized cost of hydrogen of $\$ 6.75 / \mathrm{MMBtu}$. An increase in the electricity sell price will increase the plant revenues and allow the hydrogen to be sold at a lower price while still recovering all costs and maintaining the desired return on equity; as shown in Figure 5.4.1, an increase in the electricity sell price to $\$ 50 \mathrm{MW} / \mathrm{hr}$ would allow the hydrogen sell price to be reduced to $\$ 5.68 / \mathrm{MMBtu}$.

Table 5.4.1 PCFB Plant TPC in Thousands of Year 2005 Dollars

$\begin{array}{clr}\text { Account \# } & \text { Account Title } & \\ 1 & \text { Coal \& Sorbent Handling } & 29,566 \\ 2 & \text { Coal-Water Slurry Prep \& Feed } & 30,086 \\ 3 & \text { Feedwater \& Misc BOP Systems } & 24,436 \\ 4 & \text { Gasifier \& Accessories } & 112,991 \\ 5 & \text { H2 Separation, Gas Cleanup, \& Piping } & 44,484 \\ 6 & \text { Combustion Turbine \& Accessories } & \\ 7 & \text { CFB Boiler System, Ducting, \& Stack } & 168,842 \\ 8 & \text { Steam Turbine Generator } & 64,738 \\ 9 & \text { Cooling Water System } & 20,883 \\ 10 & \text { Slag/Ash Handling Systems } & 10,835 \\ 11 & \text { Accessory Electric Plant } & 52,188 \\ 12 & \text { Instrumentation \& Control } & 24,447 \\ 13 & \text { Improvements to Site } & 10,720 \\ 14 & \text { Buildings \& Structures } & 31,197 \\ & & 625,413\end{array}$


Table 5.4.2 PCFB Plant Capital and Operating Requirements

\begin{tabular}{|c|c|c|c|c|}
\hline \multicolumn{5}{|l|}{ OPERATING REQUIREMENTS } \\
\hline & & & WMM & $1 / 21 / 06$ \\
\hline \multicolumn{5}{|l|}{ H2 \& Electric Coproduction -Foster Wheeler Partial Gasification Module } \\
\hline & & & & \\
\hline Operating Labor Rate(base) & $\$ 28.00$ & per hour & & \\
\hline Operating Labor Burden & $35 \%$ & of base & & \\
\hline Labor Overhead Charge Rate & $30 \%$ & of base & & \\
\hline Operating Labor Hours per Year & 1,944 & & & \\
\hline Administrative \& Support Labor & $45.15 \%$ & \multicolumn{2}{|c|}{ of Operating Labor } & \\
\hline & & & & \\
\hline \multicolumn{5}{|l|}{ Operating Labor Requirements (OJ) per Shift - 4 Shifts } \\
\hline Category & \multicolumn{2}{|c|}{1 Unit per Mod } & \multicolumn{2}{|c|}{ Total Plant } \\
\hline Skilled Operator & \multicolumn{2}{|c|}{3} & \multicolumn{2}{|c|}{3} \\
\hline Operator & \multicolumn{2}{|c|}{18} & \multicolumn{2}{|c|}{18} \\
\hline Foreman & \multicolumn{2}{|c|}{3} & \multicolumn{2}{|c|}{3} \\
\hline Lab Techs, etc & \multicolumn{2}{|c|}{2} & \multicolumn{2}{|c|}{2} \\
\hline Total OJs & \multicolumn{2}{|c|}{26} & \multicolumn{2}{|c|}{26} \\
\hline \multicolumn{5}{|l|}{$\begin{array}{rr}\text { CONSUMABLES } \\
\end{array}$} \\
\hline \multicolumn{5}{|l|}{ H2 \& Electric Coproduction -Foster Wheeler Partial Gasification Module } \\
\hline & \multicolumn{2}{|c|}{ Consumption } & \multicolumn{2}{|c|}{ Unit } \\
\hline & Initial & Per Day & \multicolumn{2}{|c|}{ Cost } \\
\hline Water (per 1,000gals) & $\mathrm{N} / \mathrm{A}$ & 4,636 & \multicolumn{2}{|c|}{$\$ 0.82$} \\
\hline \multicolumn{5}{|l|}{ Chemicals } \\
\hline Water Treatment (Ibs) & 336,685 & 11,223 & \multicolumn{2}{|c|}{$\$ 0.20$} \\
\hline Limestone (Tons) & 23,372 & 779 & \multicolumn{2}{|c|}{$\$ 18.00$} \\
\hline COS Catalyst (CuFt) & 0 & 0.00 & \multicolumn{2}{|c|}{$\$ 575.00$} \\
\hline Shift Catalyst (CuFt) & 237 & 0.65 & & 0.00 \\
\hline Claus Catalyst (CuFt) & 0 & 0.00 & & 5.00 \\
\hline Hdrogenation Catalyst (CuFt) & 0 & 0.00 & & 0.00 \\
\hline Amine (lbs) & 0 & 0 & & .09 \\
\hline Ammonia (lbs) & 61,200 & 2.040 & & 22 \\
\hline Other & & & & \\
\hline Supplemental Fuel (Mmbtu) & $\mathrm{N} / \mathrm{A}$ & 0 & & 5.00 \\
\hline Waste Disposal & & & & \\
\hline Ash (Tons) & $\mathrm{N} / \mathrm{A}$ & 1.183 & & 2.00 \\
\hline Slaq (Tons) & $\mathrm{N} / \mathrm{A}$ & 0 & & .00 \\
\hline BYPRODUCTS & & & & \\
\hline Sulfur (Tons) & $\mathrm{N} / \mathrm{A}$ & 0 & & 5.00 \\
\hline Excess Electric Generation (MWh) & $\mathrm{N} / \mathrm{A}$ & 6,141 & & .00 \\
\hline FUEL & & & & \\
\hline Fuel (Tons) & 59,999 & 4,000 & & .00 \\
\hline & & & & \\
\hline
\end{tabular}


Table 5.4.3 PCFB Plant Operating and Consumables Costs

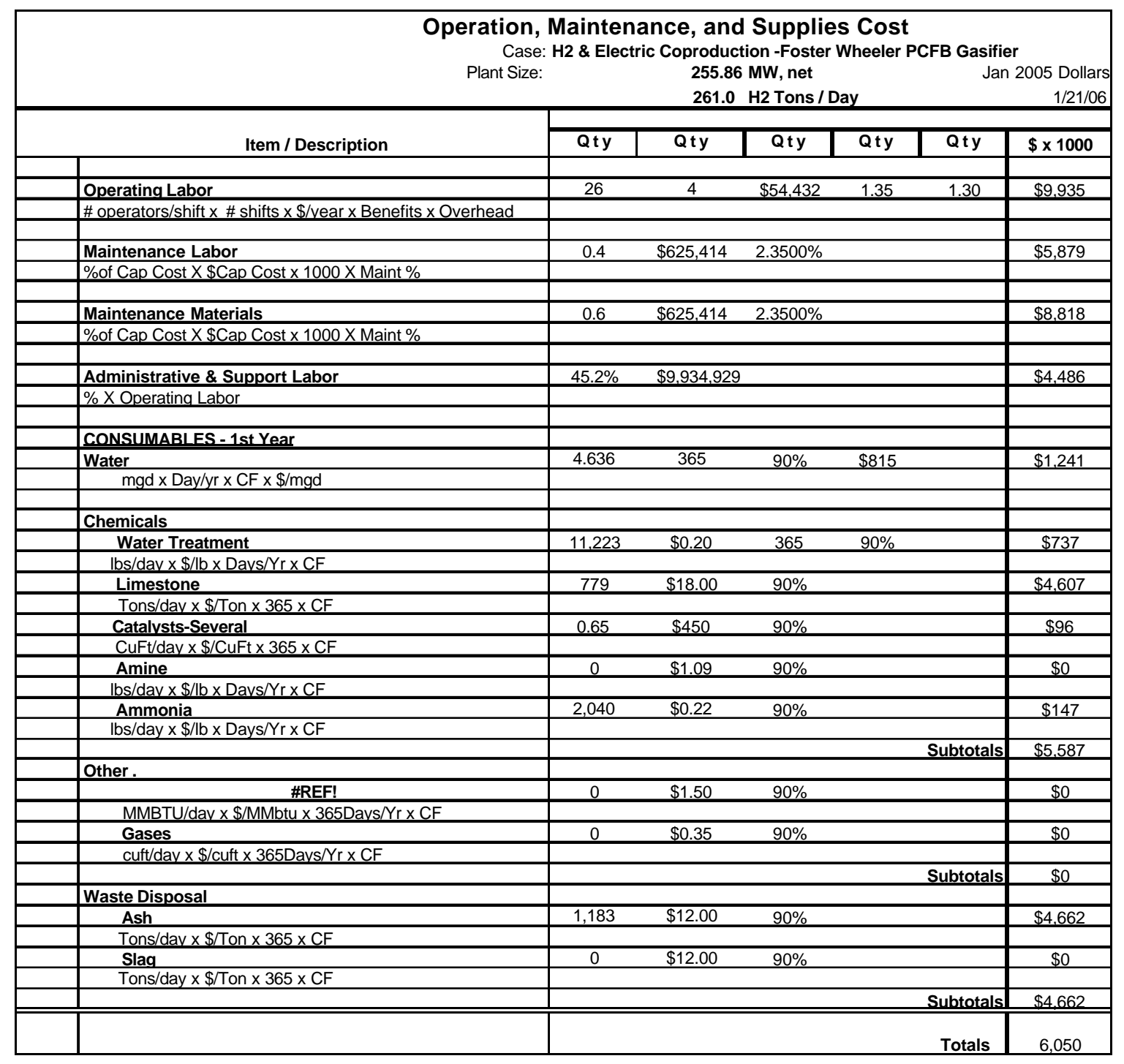


Table 5.4.4 PCFB Plant Hydrogen Production Cost

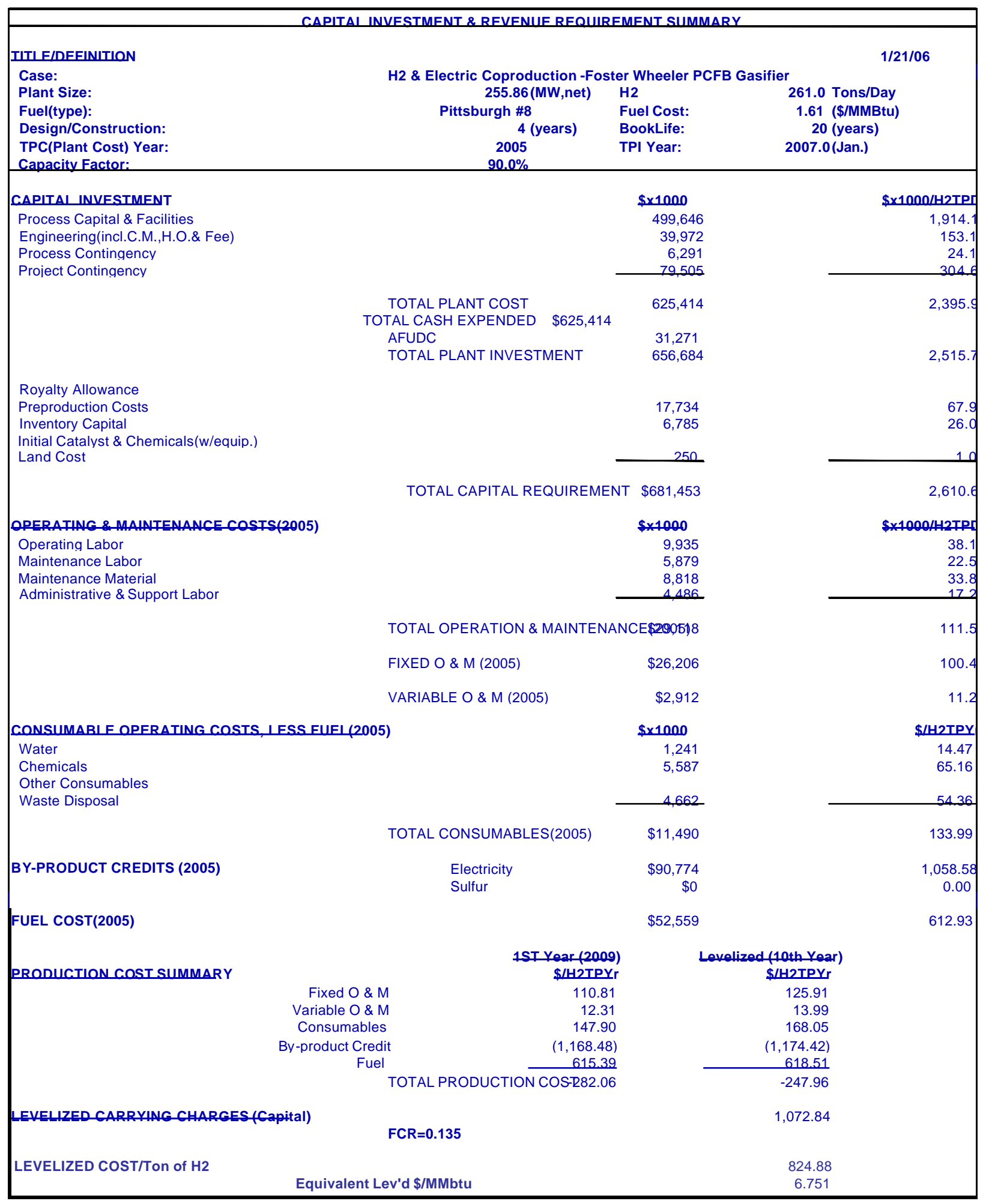




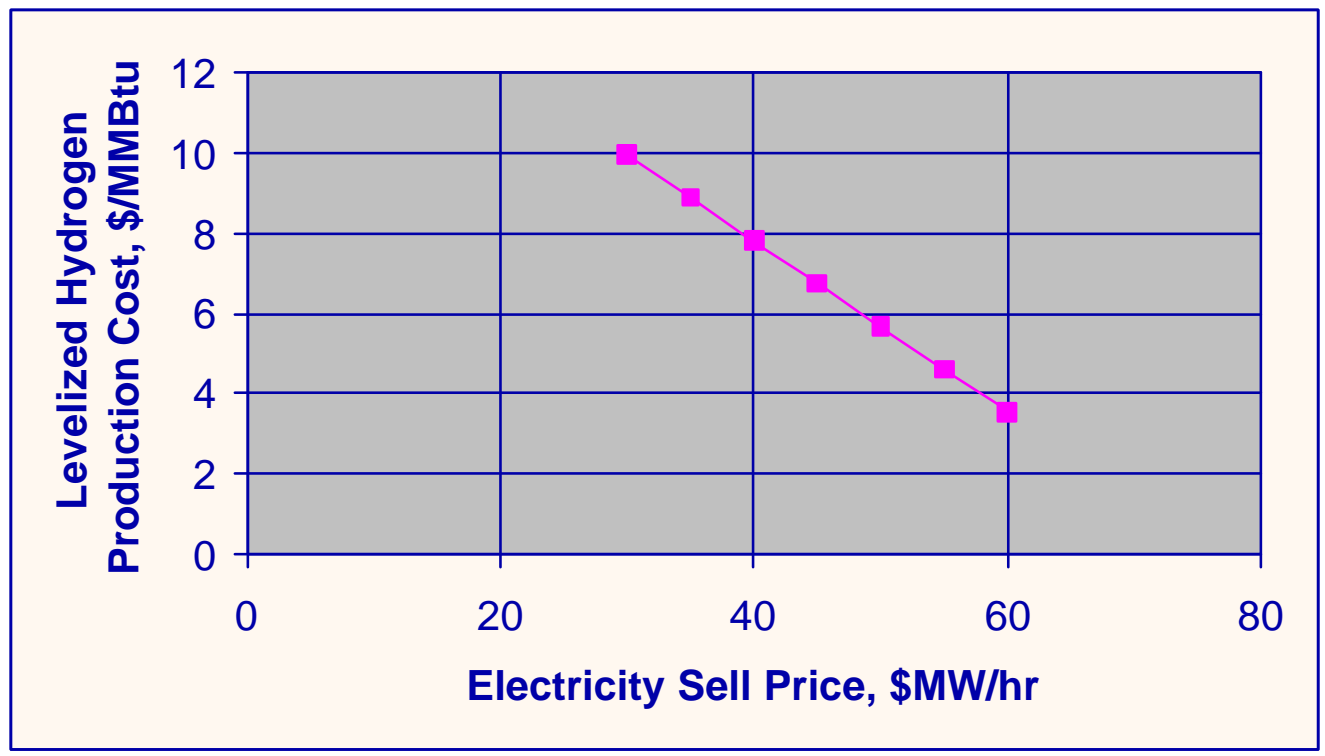

Figure 5.4.1 Effect of Electricity Sell Price on PCFB Plant Hydrogen Sell Price

\subsection{Hydrogen Production by Steam Methane Reforming (SMR)}

Hydrogen is widely produced by the steam reforming of light hydrocarbons. In this process a mixture of desulfurized natural gas and steam is typically passed over a nickel based catalyst at approximately $1500^{\circ} \mathrm{F}$ and $500 \mathrm{psig}$. The steam is supplied at roughly a 3 to 5 steam-to-carbon molar feed ratio and approximately 70 percent of the hydrocarbon is converted to oxides of carbon. Upon exiting the high alloy reformer tubes that contain the catalyst, the gas is cooled, water gas shifted, and passed through cycling PSA vessels to separate hydrogen. The vent gas/purge gas from the PSA together with supplemented natural gas is then burned to provide the heat needed by the reforming process. Figure 6.1 is a simplified process block diagram of the SMR process and Figure 6.2, extracted from a December 2004 report [6-1], presents the sell price of hydrogen produced from natural gas.

According to [6-1] the US Energy Information Agency is forecasting that natural gas prices will be in the $\$ 4.50$ to $\$ 5.00 / \mathrm{MMBtu}$ range by 2025 . In January 2005 the spot natural gas price at the Henry Hub was approximately \$6.00/MMBtu and it peaked at about \$15.00/MMBtu in September 2005. Based on Figure 6.2 and Table 5.4.4, hydrogen produced by the coal-fueled PCFB gasifier co-production plant will be competitive with SMR produced hydrogen at a natural gas price of approximately \$4/MMBtu. 


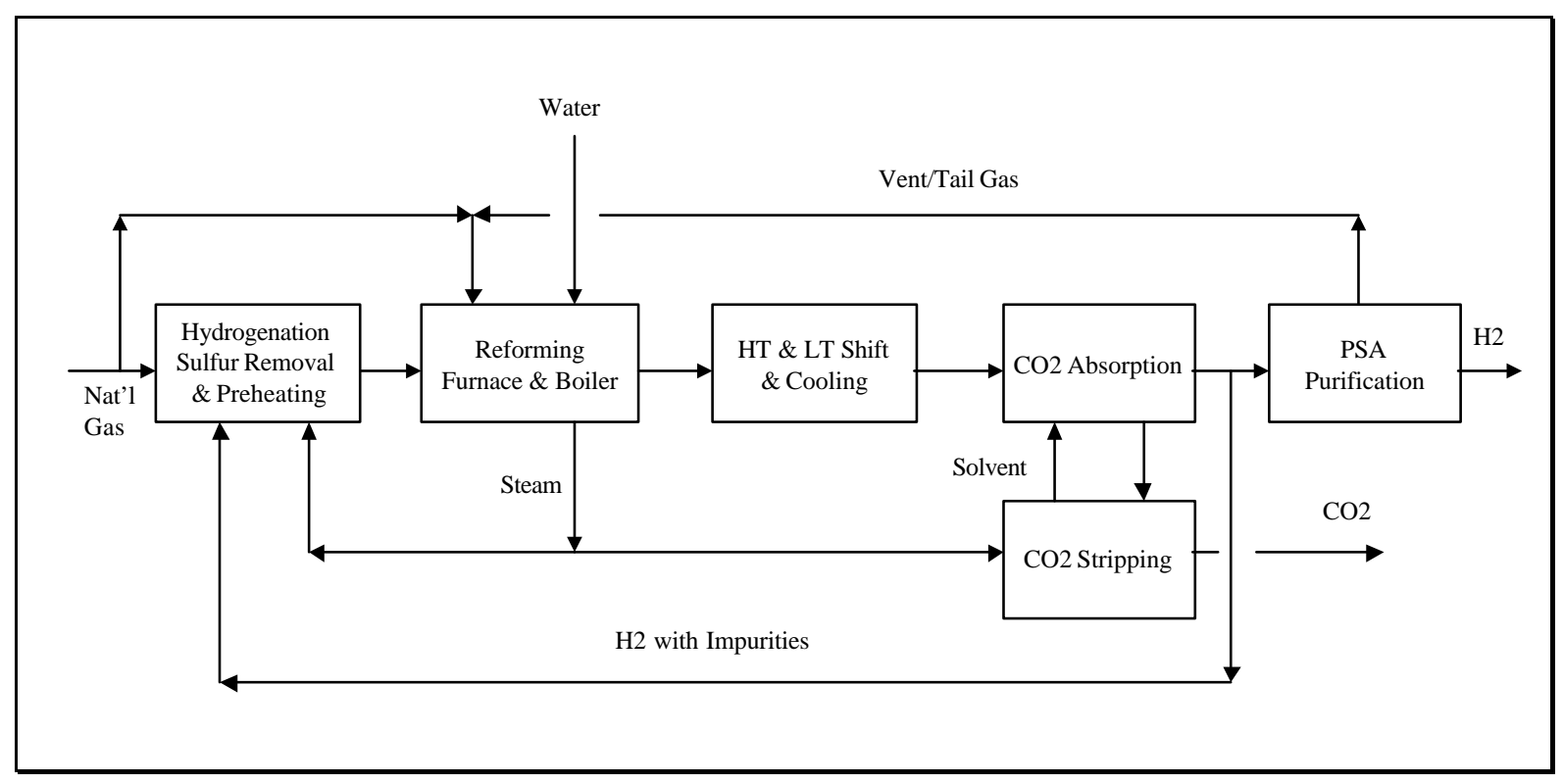

Figure 6.1 Natural Gas Steam Reforming Process Block Diagram

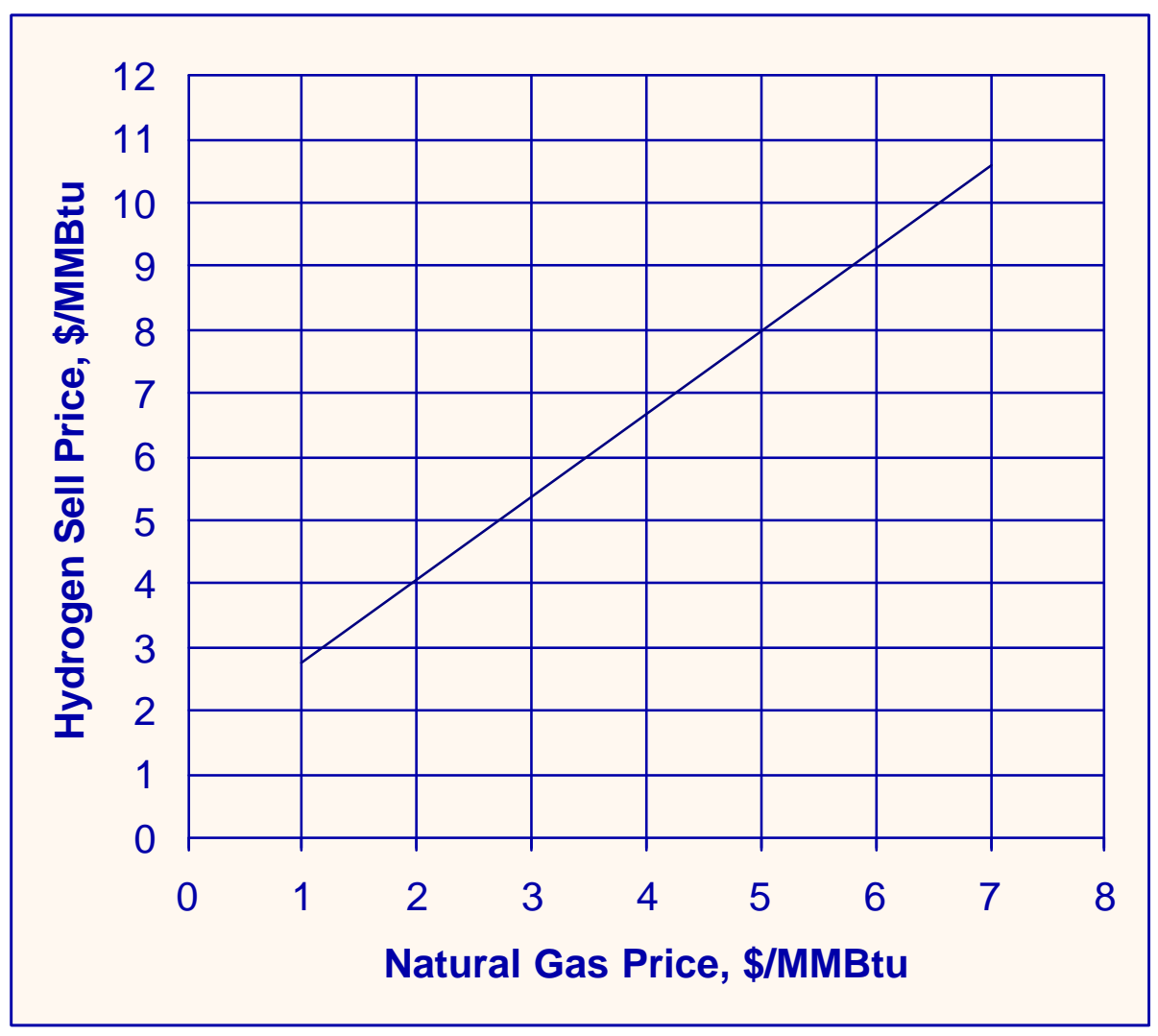

Figure 6.2 Cost of Hydrogen Produced from Steam Methane Reforming 


\subsection{Results and Discussion/Plant Comparisons}

\subsection{Redundancy and Plant Availability}

The gasifiers used by the two co-production plants studied herein represent new technologies that can affect plant availability. Both plants utilize similar systems to feed coal to their gasifiers, cool their syngas, remove gas entrained particulate, water gas shift their gases, and separate their hydrogen. Although there are some differences in solids removal systems (slag bath depressuring versus dry char depressuring) and turbine availabilities (gas turbine versus steam turbine), it is expected that the type of gasification systems employed will control the ultimate plant availability.

The high temperatures of entrained flow gasifiers $\left(\sim 2500^{\circ} \mathrm{F}\right)$ create severe operating conditions included in which are a molten slag that can corrode refractory linings and a sticky ash that can foul down stream equipment. According to [7-1], thermocouples in the gasification zone last 3045 days, burners last 2-6 months, and refractory linings on the order of 6-18 months. During the 1994 to 1997 time period four coal fueled, power producing IGCC demonstration plants started up (Buggenum, Wabash, Polk County, and Puertollano). Each had a single, high temperature, entrained flow gasifier supplied by a different manufacturer. Despite several years of operation, modifications, and improvements, the availability of these units, when fueled with coal, remains disappointingly low and there is a growing consensus that future plants will require at least a spare gasifier, if not a spare gasification equipment train, to achieve high availability [2-1], [2-2], [7-2], [7-3].

The PCFB gasifier operating temperature, in contrast, is set below the coal ash fusion temperature. As a result, it does not produce molten slag or sticky ash and it should be immune to many of the above problems. This is the same philosophy used in commercial CFB boilers which exhibit availabilities in excess of 90 percent [7-4] and a value of 95 percent is reported in [7-5]. Based on commercial scale CFB combustion and pilot scale CFB gasification experience, FW believes the relatively low operating temperature of the PCFB gasifier will eliminate the above entrained flow gasifier problems. As a result, FW believes PCFB gasifier availability will be comparable to that of its CFB boilers and its co-production plant will not require a spare gasifier.

The availabilities ultimately achievable by mature high temperature entrained flow versus low temperature circulating fluidized bed gasifiers, however, are subject to debate. As a result economic data has been presented for the entrained flow gasifier plant both with and without a spare gasifier equipment train.

\subsection{Overall Plant Arrangement}

The PCFB gasifier and the entrained flow gasifier co-production plants are similar in arrangement in that each utilizes two trains of equipment that operate in parallel; the first equipment train produces a coal derived syngas which, after processing and through the use of PSA technology, yields 99.95 percent pure, 355 psig hydrogen for sale to a refinery. The second equipment train produces electricity that is sold to the grid to provide a revenue stream that defrays the cost of hydrogen production. Although the functions of the two equipment trains are similar, they 
incorporate differing components and differing processes, which, ultimately result in different plant performance and costs.

Although both plants incorporate an oxygen blown, coal-water slurry fed gasifier to produce syngas for hydrogen production, the PCFB plant gasifier operates at a lower temperature and char fines, captured by the candle filter and pre-cleaner cyclone, are not recycled back to it; as a result, the PCFB gasifier operates with only 80.4 per cent carbon conversion efficiency. The char residue, however, is not wasted as it is burned in a CFB boiler along with coal and the vent/purge gas from the PSA to produce steam to drive a steam turbine for electric power generation. The CFB boiler utilizes limestone feed, staged air injection, ammonia injection, and a dry scrubber to control $\mathrm{SO}_{2}$ and NOx emissions and serves as the emission control device for the plant. It is also used to flare the gasifier syngas at start-up and shut-down.

The entrained flow plant gasifier is a two stage unit that operates at a much higher temperature $\left(1^{\text {st }}\right.$ stage estimated to be $\sim 2500^{\circ} \mathrm{F}$ ) and it converts its entire coal feed into a syngas and a molten ash slag waste. Since there is no char residue left for power production, an identical gasifier must be provided to produce syngas for conventional gas turbine-steam turbine combined cycle power generation. With no CFB boiler available to control the plant emissions, the entrained flow plant utilizes syngas amine washing for sulfur capture, a Claus Plant for sulfur recovery, and a separate boiler to burn its low pressure, low Btu PSA vent gas.

In summary, the PCFB plant has one gasifier, one CFB boiler, and one large steam turbine, whereas, the entrained flow plant has two gasifiers, two acid gas removal systems, an $\mathrm{H}_{2} \mathrm{~S}$ gas concentrator, one Claus Plant, one gas turbine, and two smaller steam turbines.

Although the preparation of arrangement drawings was beyond the scope of this study, some insight can be gained into the physical arrangement of the two plants from Figure 7.2.1. This figure, extracted from one of Parsons' previous studies [7-6 ], depicts a two train, E-Gas based, IGCC plant that fuels two GE 7FA gas turbines for combined cycle power generation. Based on the line scale shown in this drawing, each gasification block occupies about a $92,00 \mathrm{ft}^{2}$ footprint with its gasifier equipment train (slurry storage tanks through candle filter) occupying approximately $54,000 \mathrm{ft}^{2}$ of this area. Noting that the entrained flow plant gasifier block area is about 25 percent larger than that of the CFB boiler system, it safely represents a CFB boiler system footprint. Table 7.2.1 presents a qualitative comparison of the two co-production plant arrangements and it indicates that the PCFB gasifier based co-production plant should require less land, especially when a third/spare train of gasifier equipment is added to the plant. Since no coproduction plant drawings were prepared to quantify the Table 7.1.1 comparison, the footprint advantage of the PCFB plant, which would also lead to lower structural steel, wiring, piping, site preparation work, etc. costs, was ignored in the cost and economic evaluations. 
Table 7.2.1 Comparison of Co-Production Plant Foot Prints (See Figure 7.2.1)

Co-Production Plant

Right Hand Gasifier Block

7FA Gas Turbines

Steam Turbine Building

Cooling Towers

ASU

Acid Gas and Sulfur Recovery

$\mathrm{H}_{2} \mathrm{~S}$ Gas Concentrator System

Waste Water Treatment

Spare Gasifier Train ( 54,000 $\left.\mathrm{FT}^{2}\right)$

Slurry Prep
PCFB Gasifier Based

Replace with CFB System

Eliminate Both

Similar

Keep Unchanged

Reduce by $50 \%$

Eliminate All

Not Required

Reduce in Size

Not Required

Reduce in Size
E-Gas Based

Keep Unchanged

Keep One

Similar

Reduce by $50 \%$

Keep Unchanged

Keep Unchanged

Add

Keep Unchanged

Add

Keep Unchanged 


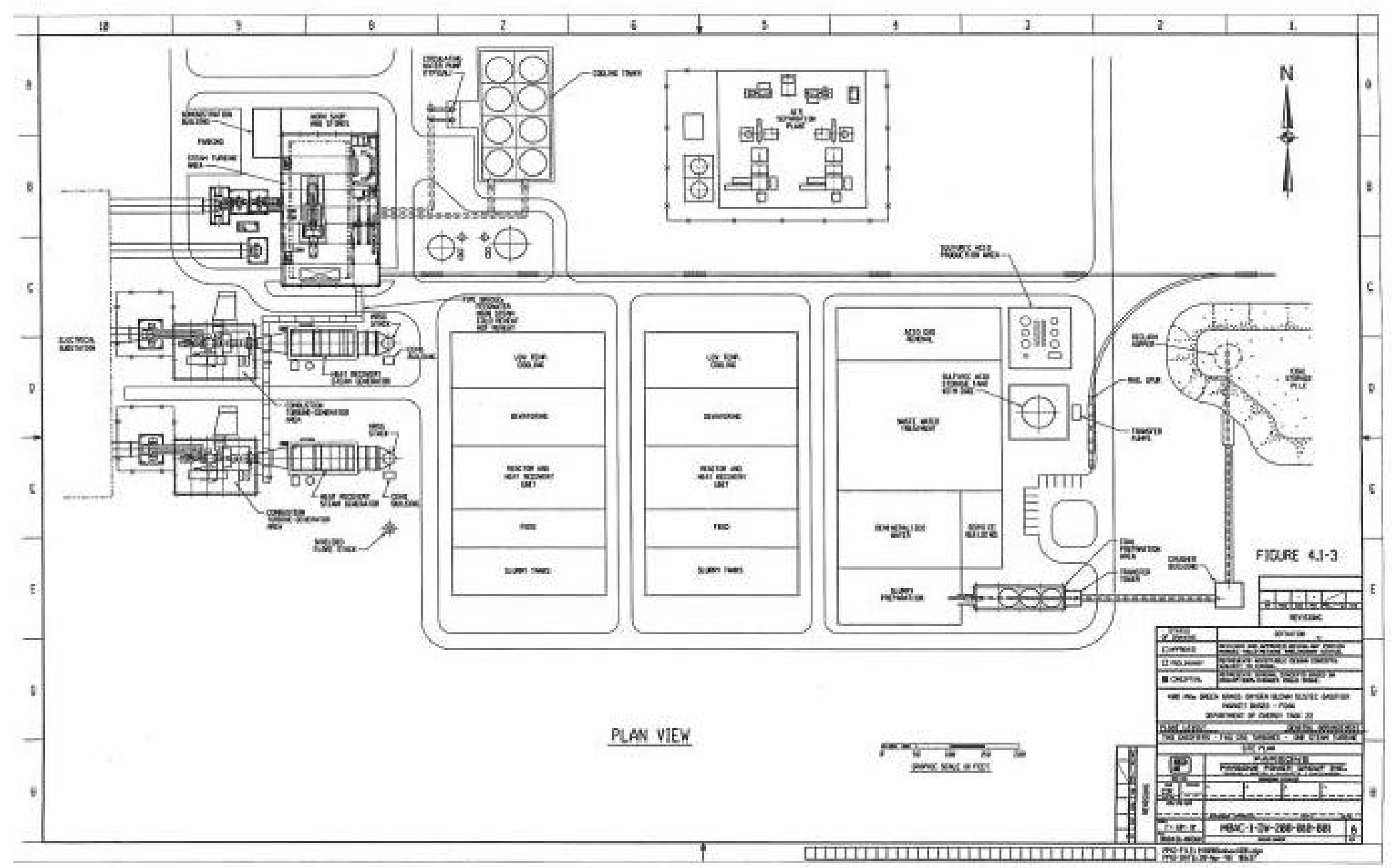

Figure 7.2.1 Two Train IGCC Combined Cycle Plant Arrangement 


\subsection{Plant Performance}

The differences between the two plants are ultimately attributed to the gasification technology they employ. The entrained flow plant uses a high temperature, high carbon conversion gasifier that necessitates cold gas cleanup and combined cycle power generation. The PCFB plant uses a lower temperature, lower carbon conversion gasifier which necessitates use of a CFB boiler for char combustion and a steam turbine for power generation. Although the gasification technologies are different, both plants require oxygen, syngas cooling, syngas particulate removal, water gas shifting, and PSA technology. To permit a consistent comparison, the PCFB gasifier plant has been designed to use the same slurry feed and oxygen supply systems as well as the same syngas processing components with the latter operating at similar temperatures.

Table 7.3.1 compares the performance of the two plants. With both plants designed to produce the same amount of hydrogen and electricity, the effective thermal efficiency of the PCFB gasifier based co-production plant is 5.4 percentage points higher than the entrained flow plant (53.0 versus 47.6 percent).

Some of the factors that enable the PCFB gasifier plant to operate with a higher effective thermal efficiency are that it:

1.) uses less process steam

2.) condenses less steam from its syngas

3.) requires less parasitic power

4.) has a lower stack energy loss

5.) utilizes a more efficient steam cycle/steam turbine

The gas turbine and cold gas clean-up/acid gas removal system used by the entrained flow plant contribute to its lower efficiency. With the gas turbine fueled with syngas, the entrained flow plant syngas production rate is 69 percent higher than the PCFB plant. This gas undergoes acid gas removal by amine solvent and 141,182 $\mathrm{lb} / \mathrm{hr}$ of steam is diverted from the plant steam cycle for its regeneration. Since the syngas is cooled to approximately $100^{\circ} \mathrm{F}$ for delivery to the acid gas system, steam is condensed during the cooling of the syngas and, with the heat of condensation being transferred to low temperature cooling water, much of it is at too low of a temperature to be used efficiently by the steam cycle. Although the PCFB gasifier plant also cools its syngas to a similar temperature (a requirement of the PSA system), its syngas flow rate is lower and, hence, its condensation loss is lower. Similarly, the PCFB plant slurry and oxygen production rates are lower with the former requiring less steam to be extracted from the steam cycle for slurry heating and the latter leading to lower ASU and oxygen compression power losses. The entrained flow gasifier plant's higher parasitic power draw is further exacerbated by the use of nitrogen to control gas turbine NOx emissions (nitrogen compression requires $24.5 \mathrm{MWe}$ of power). On an overall basis the parasitic power draw of the entrained flow plant is approximately 42 MWe higher than the PCFB gasifier plant and, as seen from Table 7.3.2, the ASU and oxygen and nitrogen compression systems are major causes of this disadvantage. The gas turbine operates at a much higher excess air level than the CFB boiler and, as a result, the entrained flow plant, with a 79 percent higher stack gas flow rate, has a higher stack gas energy loss. 


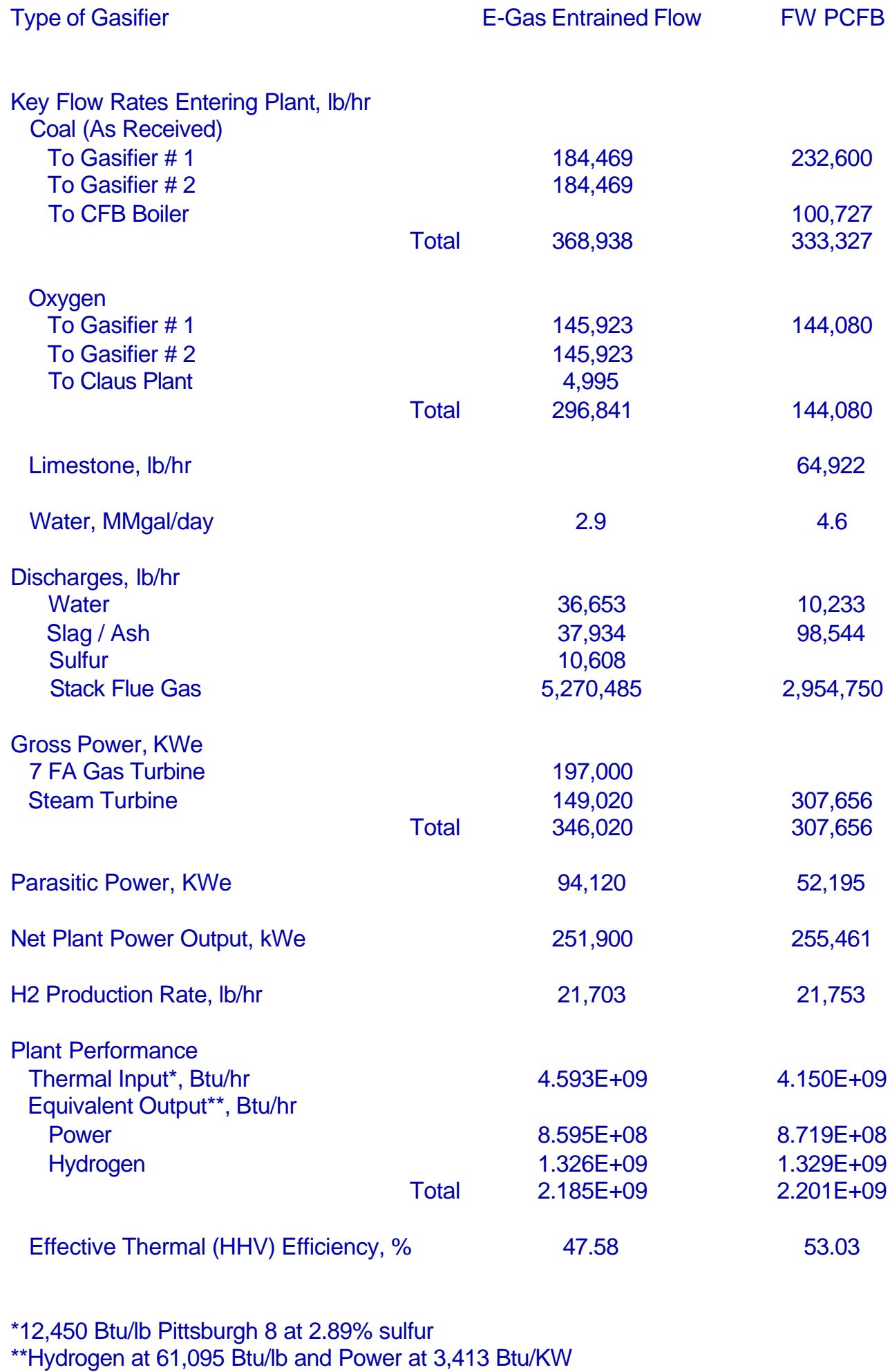


Table 7.3.2 Comparison of Co-Production Plant Parasitic Power (KWe)

\begin{tabular}{|c|c|c|c|c|}
\hline \multirow[t]{2}{*}{ Type of Gasifier } & \multicolumn{2}{|c|}{-----E-Gas Entrained Flow---- } & \multicolumn{2}{|c|}{-----------FW PCFB--------.- } \\
\hline & Process Areas & Totals & Process Areas & Totals \\
\hline Solids Handling/Crushing/Pumping & 2,180 & 2,180 & 1,340 & 1,340 \\
\hline $\begin{array}{l}\text { Air Separation Unit Auxiliaries } \\
\text { Oxygen Compressors } \\
\text { Nitrogen Compressor }\end{array}$ & $\begin{array}{l}31,200 \\
17,160 \\
24,500\end{array}$ & & $\begin{array}{c}15,400 \\
7,060\end{array}$ & \\
\hline & & 72,860 & & 22,460 \\
\hline $\begin{array}{l}\text { Fines and Claus Recycle } \\
\text { Amine \& Claus Auxiliaries } \\
\text { Fired Boiler Air Fan }\end{array}$ & $\begin{array}{l}4,340 \\
2,340 \\
1,250\end{array}$ & & & \\
\hline CFB Fans and Dry Scrubber & & 7,930 & 10,735 & 10,735 \\
\hline $\begin{array}{l}\text { Condensate and Boiler Feed Pumps } \\
\text { Circ Water and Cooling Tower }\end{array}$ & $\begin{array}{l}2,740 \\
3,380\end{array}$ & & $\begin{array}{l}8,660 \\
5,700\end{array}$ & \\
\hline & & 6,120 & & 14,360 \\
\hline Miscellaneous & 5,030 & 5,030 & 3,300 & 3,300 \\
\hline Totals & 94,120 & 94,120 & 52,195 & 52,195 \\
\hline
\end{tabular}

With the PCFB gasifier plant operating at a higher efficiency, the entrained flow plant requires an additional $443 \mathrm{MM} \mathrm{Btu/hr}$ of heat input to produce the same amount of hydrogen and electricity. Table 7.3.3 attempts to quantify/identify how much each of the above factors/differences contribute to the entrained flow plant need for additional energy. Since steam condensations are occurring at a variety of process conditions, for simplicity sake, the condensation loss has been estimated assuming a $950 \mathrm{Btu} / \mathrm{lb}$ heat of condensation. Table 7.3.3 reveals that syngas steam condensation is the dominant loss, being almost double that of the next larger component, parasitic power. Hence, even if the PCFB plant parasitic power were increased to match that of the entrained flow, possibly by converting the CFB boiler to oxy-firing to facilitate $\mathrm{CO}_{2}$ sequestration, the PCFB gasifier plant would still be more efficient. 
Table 7.3.3 Comparison of Co-Production Plant Energy Losses

\begin{tabular}{|c|c|c|c|c|}
\hline Type of Gasifier & Entrained Flow & PCFB & -Entrained Flow Plant Gr & 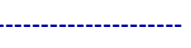 \\
\hline $\begin{array}{l}\text { Process Steam, lb/hr } \\
\text { Condensed from Syngas }\end{array}$ & & & & \\
\hline $\begin{array}{r}\text { H2 Train } \\
\text { Power Train }\end{array}$ & $\begin{array}{l}110,856 \\
30,326\end{array}$ & 98,814 & & \\
\hline To Amine Reboilers & & & & \\
\hline Reboiler \# 1 & 90,919 & & & \\
\hline Reboiler \# 2 & 50,293 & & & \\
\hline To Sour Water Stripper & 39,461 & 19,069 & & \\
\hline To Waste Water Treatment & 64,352 & & & \\
\hline Total & 386,207 & 117,883 & $268,324 \mathrm{lb} / \mathrm{hr}$ at say $950 \mathrm{Btu} / \mathrm{lb}$ & $255 \mathrm{MM} \mathrm{Btu/hr}$ \\
\hline Parasitic Power Consumption, KWe & 94,120 & 51,797 & $42,323 \mathrm{KWe}$ at $3,413 \mathrm{Btu} / \mathrm{KWe}$ & $144 \mathrm{MM} \mathrm{Btu} / \mathrm{hr}$ \\
\hline Stack Gas Flow Rate, lb/hr & $5,270,485$ & $2,954,270$ & $\begin{array}{r}2,316,215 \mathrm{lb} / \mathrm{hr} \text { at say cp of } 0.214 \\
\text { Btu/lb and } 200 \mathrm{~F} \text { delta } \mathrm{T}\end{array}$ & $99 \mathrm{MM} \mathrm{Btu/hr}$ \\
\hline
\end{tabular}

The higher efficiency of the PCFB gasifier plant leads to lower consumables. The PCFB gasifier plant operates with 9 percent less coal, 51 percent less oxygen, and 44 percent less stack gas. Although the PCFB based plant does not require amine and nitrogen for $\mathrm{SO}_{2}$ and $\mathrm{NOx}$ control, its use of limestone for $\mathrm{SO}_{2}$ control results in a solid waste flow rate approximately double that of the entrained flow plant, e.g., 98,544 versus 48,524 lbs/hr.

\subsection{Plant Emissions}

The stack emissions of the two plants are presented on pound per hour and pound per million Btu of total plant heat input bases in Table 7.4.1. In the PCFB gasifier based plant the CFB boiler system controls the plant emissions; its pound per hour values were calculated using the pound per million Btu emission rates measured with Pittsburgh No 8 coal in the Jacksonville Electric Authority 300 MWe CFB Boiler Demonstration Project [5-1]. Since the CFB boiler heat release is approximately 60 percent of the total plant heat input, these values were then expressed on a total plant heat input basis yielding the values shown.

The emissions of the entrained flow plant are the total of those contained in the exhaust from its 7FA gas turbine and its PSA vent gas fired boiler. The Wabash IGCC Demonstration Plant, which incorporated an E-Gas gasifier, an amine scrubber for sulfur capture, a Claus Plant for sulfur recovery, and a GE 7FA gas turbine, operated with $\mathrm{SO}_{2}$ and $\mathrm{NOx}$ emissions rates of 0.13 and 0.08 $\mathrm{lb} / \mathrm{MMBtu}$ respectively [4-1]. To reduce these emission rates, the entrained flow gasifier based plant recycles the Claus Plant tail gas back to the gasifier and injects nitrogen into the gas turbine combustor. Parsons projects that these steps will reduce the $\mathrm{SO}_{2}$ emission rate to $0.023 \mathrm{lb} / \mathrm{MMBtu}$ (99.5 percent sulfur capture efficiency) and the NOx emission rate to $0.067 \mathrm{lb} / \mathrm{MMBtu}$ (15 ppmvd). Using these new values, together with those projected for the PSA vent gas fired boiler, Parsons determined the plant pound per hour emission rates and then expressed them on a total plant heat input basis. 
As shown in Table 7.4.1, the NOx and particulate emissions of the two plants are comparable with the most significant differences occurring in $\mathrm{SO}_{2}$ and $\mathrm{CO}$ emissions. Recycling the Claus Plant tail gas back to the gasifier is expected to increase the sulfur capture efficiency of the entrained flow gasifier plant from the Wabash 98 per cent plus values to 99.5 percent. With this improvement the entrained flow gasifier plant $\mathrm{SO}_{2}$ emission is about $1 / 3^{\text {rd }}$ of that of the PCFB gasifier plant as the latter operates with a 98.5 per cent sulfur capture efficiency. In contrast, the $\mathrm{CO}$ emission rate of the PCFB gasifier based plant is about $1 / 5^{\text {th }}$ of that of the entrained flow gasifier plant.

Table 7.4.1 Comparison of Co-Production Plant Emissions

\begin{tabular}{|c|c|c|}
\hline Type of Gasifier & Entrained Flow & PCFB \\
\hline \multicolumn{3}{|l|}{ SO2 } \\
\hline$\%$ Capture & 99.5 & 98.5 \\
\hline $\mathrm{lb} / \mathrm{hr}$ & 106.9 & 289 \\
\hline lb/MMBtu & 0.023 & 0.070 \\
\hline \multicolumn{3}{|l|}{ NOx } \\
\hline $\mathrm{lb} / \mathrm{hr}$ & 194 & 197 \\
\hline lb/MMBtu & 0.042 & 0.048 \\
\hline \multicolumn{3}{|l|}{$\mathrm{CO}$} \\
\hline $\mathrm{lb} / \mathrm{hr}$ & 297 & 45.1 \\
\hline lb/MMBtu & 0.065 & 0.011 \\
\hline \multicolumn{3}{|l|}{ Particulate } \\
\hline $\mathrm{lb} / \mathrm{hr}$ & 3.7 & 16.6 \\
\hline $\mathrm{lb} / \mathrm{MMBtu}$ & 0.001 & 0.004 \\
\hline
\end{tabular}

\subsection{Plant Costs and Economics}

Table 7.5.1 compares the cost and economics of the PCFB and entrained flow gasifier coproduction plants, the latter both with and without a spare gasifier equipment train. In both cases the PCFB based plant has the lowest total plant cost of \$625.4 million; this cost is 7.8 and 3.5 percent lower than the 3 and 2 train plants, respectively. This cost advantage will increase further if the PCFB gasifier plant's smaller site footprint is taken into consideration and the plant site is moved to a warm weather climate (the latter eliminates the need for the $\$ 13$ million CFB boiler building). Although the PCFB gasifier plant operates with a higher efficiency that gives it a lower fuel cost, its use of limestone, rather than amine solvent for sulfur capture, adds to its consumables cost. The limestone brings with it a feed cost of $\$ 18 /$ ton and increases the amount of plant solid waste for disposal costing $\$ 12 /$ ton. These cost adders together with, primarily, the assumed sale of sulfur at $\$ 75 /$ ton by the entrained flow gasifier plant, give the entrained flow plant a $\sim 2$ percent lower consumable cost. Despite this, the PCFB gasifier based plant, with its lower total plant cost and lower maintenance costs, has the lowest 10 year levelized hydrogen production price of $\$ 6.75 / \mathrm{MMBtu}$; this cost is 4.4 per cent less than the entrained flow plant with a spare train of 
gasification equipment and, per Figure 6.2, is competitive with hydrogen produced by steam methane reforming at a natural gas price of approximately $\$ 4$ per million Btu.

The technologies employed by the two different co-production plants can be expected to advance with maturity and yield reductions in their hydrogen production costs. For the entrained flow plant this is envisioned as eliminating the spare train of gasification equipment for a $\$ 0.46 / \mathrm{MMBtu}$ reduction in hydrogen costs. Although this would make the "future" entrained flow co-production plant competitive with the "present day" PCFB co-production plant, the latter's production costs are also expected to reduce via technology maturity and its cost advantage maintained.

Table 7.5.2 compares the plants at the total plant cost account level and reveals the following major cost differences:

1.) With the entrained flow plant having, among other things, three gasification equipment trains, higher coal and oxygen flow rates, and solvent based sulfur capture, the following of its accounts are significantly higher:

a.) Account 2 covering coal-water slurry preparation/feeding equipment

b.) Account 4 containing gasifiers, fire-tube boilers, cyclones, filters, and oxygen supply systems

c.) Account 5 involving amine based sulfur removal, $\mathrm{H}_{2} \mathrm{~S}$ concentration, sulfur recovery, and syngas reheating, and humidification (PSA costs are the same as the PCFB gasifier plant)

d.) Account 6 containing the gas turbine

e.) Account 10 involving slag dewatering, handling, and storage

2.) With the PCFB gasifier plant incorporating a large CFB boiler system and a large steam turbine, the following of its accounts are significantly higher:

f.) Account 3 covering feedwater equipment

g.) Account 7 containing CFB boiler, fans, air heater, dry scrubber, baghouse filter, etc

h.) Account 8 containing the steam turbine

i.) Account 9 covering the cooling water system

j.) Account 14 containing the large $\$ 13$ million building that encloses the CFB boiler 
Table 7.5.1 Comparison of Plant Capital Investments and Economics

Type of Gasifier

Number of Gasification Equipment Trains

Plant Capacity Factor, \%

Net Power Output, MWe

Hydrogen Production Rate, lb/hr

Total Plant Cost, \$MM

Total Plant Investment, \$MM

Total Capital Requirement, \$MM

1st Year Operating \& Maintenance Cost, \$MM

1st Year Consumables Cost Less Fuel, \$MM

Water

Water Treatment

Limestone

Catalysts

Amine

Ammonia

Waste Disposal

Subtotal

0.8

0.5

0.4

0.1

21,703

21,703

21,753

678.5

647.8

625.4

712.4

680.1

656.7

738.2

705.2

681.5

33.1

32.2

29.1

1st Year Byproduct Credit, \$MM

$$
\begin{array}{r}
\text { Electricity } \\
\text { Sulfur }
\end{array}
$$

89.4

3.1

1.8

3.6

0.8

1.2

0.5

0.8

4.6

0.4

0.1

0.1

1.8

0.1

4.7

3.6

11.5

1st Year Fuel Cost, \$MM

58.2

58.2

52.6

Levelized Cost of Hydrogen, \$/MMBtu

7.063

6.60

6.75

*Includes One Spare Train

${ }^{* *}$ Allows for Technology Advancements that Eliminate Spare Train 
Table 7.5.2 Comparison of Total Plant Costs by Accounts

\begin{tabular}{|c|c|c|c|c|c|}
\hline & Type of Gasifier & $\begin{array}{c}\text { E-Gas } \\
\text { Entrained } \\
\text { Flow }\end{array}$ & $\begin{array}{c}\text { FW } \\
\text { PCFB }\end{array}$ & $\begin{array}{l}\text { Difference } \\
\text { E-Gas } \\
\text { minus FW }\end{array}$ & $\begin{array}{c}\% \text { Differenc } \\
\text { From } \\
\text { E-Gas }\end{array}$ \\
\hline & Number of Gasifiers & 3 & 1 & & \\
\hline Acct \# & Account Title & & & & \\
\hline 1 & Coal \& Sorbent Handling & 32,369 & 29,566 & $-2,803$ & -8.7 \\
\hline 2 & Coal-Water Slurry Prep \& Feed & 40,909 & 30,086 & $-10,823$ & -26.5 \\
\hline 3 & Feedwater \& Misc BOP Systems & 19,766 & 24,436 & 4,670 & 23.6 \\
\hline 4 & Gasifier \& Accessories & 211,715 & 112,991 & $-98,724$ & -46.6 \\
\hline 5 & H2 Separation, Gas Cleanup, \& Piping & 91,051 & 44,484 & $-46,567$ & -51.1 \\
\hline 6 & Combustion Turbine \& Accessories & 58,099 & & $-58,099$ & \\
\hline 7 & CFB Boiler Syst/HRSG, Ducting, \& Stack & 49,885 & 168,842 & 118,957 & 238.5 \\
\hline 8 & Steam Turbine Generator & 31,919 & 64,738 & 32,819 & 102.8 \\
\hline 9 & Cooling Water System & 13,922 & 20,883 & 6,961 & 50.0 \\
\hline 10 & Slag/Ash Handling Systems & 17,477 & 10,835 & $-6,642$ & -38.0 \\
\hline 11 & Accessory Electric Plant & 55,916 & 52,188 & $-3,728$ & -6.7 \\
\hline 12 & Instrumentation \& Control & 26,193 & 24,447 & $-1,746$ & -6.7 \\
\hline 13 & Improvements to Site & 10,720 & 10,720 & & 0.0 \\
\hline \multirow[t]{2}{*}{14} & Buildings \& Structures & 18,559 & 31,197 & $\begin{array}{c}12,638 \\
0\end{array}$ & 68.1 \\
\hline & Total & 678,500 & 625,413 & $-53,087$ & -7.8 \\
\hline
\end{tabular}

\section{6 $\mathrm{CO}_{2}$ Sequestering}

There is growing concern that $\mathrm{CO}_{2}$ emissions may have a detrimental effect on future weather/climate conditions. If needed, both co-production plants can be redesigned to incorporate $\mathrm{CO}_{2}$ removal/separation for sequestration. Although analyses have not been performed, it is anticipated the plants would require the following major changes:

Entrained Flow Plant Changes

1.) add water gas shift to the power producing combined cycle leg of the plant

2.) add a $\mathrm{CO}_{2}$ absorption tower to each plant leg downstream of their respective $\mathrm{H}_{2} \mathrm{~S}$ absorption towers 
3.) add a $\mathrm{CO}_{2}$ stripping tower servicing both legs of the plant

4.) add a $\mathrm{CO}_{2}$ processing unit (dries and compresses $\mathrm{CO}_{2}$ to pipeline pressure)

5.) convert the gas turbine to firing a hydrogen rich syngas

\section{PCFB Plant Changes}

1.) add $\mathrm{CO}_{2}$ absorption and stripping towers to the syngas production leg of the plant

2.) add a second ASU system to the plant to supply oxygen to the CFB boiler

3.) redesign the CFB boiler for oxy-combustion (CFB fired with oxygen rather than air)

4.) add a $\mathrm{CO}_{2}$ processing unit (dries and compresses $\mathrm{CO}_{2}$ to pipeline pressure)

A detailed study, however, is needed to prepare plant heat and material balances, establish equipment design requirements, estimate equipment costs, and determine their impact on plant performance and economics.

\subsection{Conclusions}

Previous studies have shown that an air blown, fluidized bed gasifier, producing a low Btu syngas and a char sorbent residue, can be used to fuel a highly efficient combined cycle power generation plant. Such a plant, incorporating a Siemens Westinghouse 501G gas turbine, a conventional subcritical pressure steam turbine, and a PCFB boiler, is projected to have an efficiency of 48.2 percent (coal higher heating value basis) and a total plant cost of $\$ 1,079 / \mathrm{KW}$ [8-1].

This study has investigated the feasibility of using the syngas from the PCFB gasifier to produce hydrogen rather than power a gas turbine. For such an application the PCFB gasifier is operated with oxygen instead of air to minimize the cost of gas processing equipment. When operated with oxygen, the PCFB gasifier produces a medium Btu syngas that has a hydrogen to carbon monoxide molar ratio favorable for the production of hydrogen. By incorporating water gas shifting and PSA technology the hydrogen can be separated from the syngas for sale to, in this study, a nearby refinery. The char residue from the PCFB gasifier and the PSA vent/purge gas are used to fuel a CFB boiler that produces steam for the gasifier and to drive a steam turbine for electric power generation. As a result, a PCFB gasifier based co-production plant is formed and the revenue from the sale of its electric power is used to defray the cost of hydrogen production.

If the coal-fueled, PCFB gasifier co-production plant sells its electricity at a price of $\$ 45 / \mathrm{MWhr}$, its 99.95 per cent pure hydrogen can be sold at a price of $\$ 6.75 / \mathrm{MMBtu}$, a price, per Figure 6.2, competitive with the steam methane reforming of $\$ 4 / \mathrm{MMBtu}$ natural gas. With current natural gas spot prices well over this value, the potential for coal-fueled hydrogen production is promising. Any increase in the electricity sell price will increase the co-production plant revenue and enable its hydrogen sell price to be lowered while still recovering all costs and maintaining a 12 per cent return on equity; if the electricity sell price increases to $\$ 50 / \mathrm{MWhr}$ then the hydrogen sell price, per Figure 5.4.1, can be reduced to \$5.68/MMBtu.

The performance and economics of the PCFB gasifier based co-production plant has also been compared to a comparable plant incorporating two stage, entrained flow gasification as exemplified by the E-Gas ${ }^{\mathrm{TM}}$ gasifier at the Clean Coal Technology Wabash River Repowering 
Project. Based on analyses performed by Parsons, the hydrogen and total plant cost of the PCFB gasifier based plant will be lower by at least 4.4 and 7.8 percent respectively.

Although not evaluated in this study, the PCFB gasifier based co-production plant can also incorporate $\mathrm{CO}_{2}$ removal for sequestration; a detailed study, however, would have to be conducted to finalize its plant arrangement and determine the resulting plant performance and economics.

Based on the analyses conducted in this study, a coal-fueled, PCFB gasifier based co-production plant appears to be an economically viable means for meeting the nation's future needs for hydrogen and electricity.

\subsection{References}

1-1 Gupta, G, and McKensey, R., "Vision 21 Plants Utilizing HIPPS Technology”, presented at Globe Ex 2000 International Energy Conference, Las Vegas, NA, July 23-28, 2000.

1-2 Rao, A.D., and Robson, F.L, "Vision 21-Coal Based Systems Integration", presented at $28^{\text {th }}$ International Technical Conference on Coal Utilization \& Fuel Systems, Clearwater, FL, March 10-13, 2003.

1-3 "Evaluation of Innovative Fossil Fuel Power Plants with $\mathrm{CO}_{2}$ Removal", EPRI, Palo Alto, CA, US DOE-Office of Fossil Energy, Germantown, MD and USDOE NETL, Pittsburgh, PA: 2000. 1000316

1-4 Rutkowski, M. D. et. al., "Capital and Operating Cost of Hydrogen Production from Coal Gasification”, NETL Contract No DE-AM26-99FT40465, April 2003.

1-5 Goldstein, H., and McMahon, W., "Input to Comparative Study of Hydrogen CoProduction Cost---Foster Wheeler Partial Gasification Module versus E-Gas Multi-Train Gasifiers", January 2006.

2-1 Jorgensen, J., “The Mesaba Energy Project”, Gasification Technologies 2005, San Francisco Ca., October 9-12, 2005.

2-2 Rigdon, R., and Avidan, A., "GE Energy and Bechtel's IGCC Reference Plant Offering”, Gasification Technologies 2005, San Francisco CA., October 9-12, 2005.

3-1 Lynch,T., "Operating Experience at the Wabash Coal Gasification Repowering Project", Gasification Technologies 1998, San Francisco, CA., October, 1998.

3-2 "Thermie Demonstrates Biomass CFB Gasifier at Lahti”, Modern Power Systems, Februry 1998.

3-3 Nieminen, J., et. al., "Progress Report: Varnamo Biomass Gasification Plant", Gasification Technologies 1999, San Francisco, CA., October 17-20, 1999. 
3-4 Electric Power Research Institute, "TAG-Technical Assessment Guide", Vol 1, EPRI TR102276-V1R7, Palo Alto, CA, Rev 7 June 1993.

4-1 ConocoPhillips, "E-Gas Technology for Coal Gasification", Presentation Made to Indiana Utility Regulatory Commission June 15, 2005.

5-1 Black and Veatch, "Fuel Capability Demonstration Test Report 1 for the JEA Large-Scale CFB Combustion Demonstration Plant", Rev. 1, September 3, 2004, DOE Contract No. DE-FC21-90MC27403.

6-1 Gray, D., et. al. "Polygeneration of SNG, Hydrogen, Power, and Carbon Dioxide from Texas Lignite”, NETL Contract No. DE-AM26-99FT40465, December 2004.

7-1 Steigel, G. et. al., "DOE's Gasification Industry Interviews: Survey of Market Trends, Issues, and R\&D Needs", Gasification Technologies 2001, San Francisco Ca., October 7 $10,2001$.

7-2 Amick, A. et. al., "An Advanced IGCC Coal Power Plant”, Twentieth Annual International Pittsburgh Coal Conference, Pittsburgh PA., September 15-19, 2001.

7-3 Holt, N. et. al., "Summary of Recent IGCC Studies of $\mathrm{CO}_{2}$ Capture for Sequestration”, Gasification Technologies 2003, San Francisco CA., October12-15, 2003.

7-4 EPRI., “Atmospheric Fluidized Bed Combustion Technology’s Status Reviewed”, EPRI Journal On-Line, June 9, 2004.

7-5 Maryamchik, M. and Wietzke, D., "B\&W IR-CFB Boiler Operating Experience Update and Design", Power-Gen International 1999, November 30-December 2, 1999, New Orleans LA.

7-6 DOE Report Number DOE/FE-0400, "Market Based Advanced Coal Power Systems--Final Report", May 1999.

8-1 Robertson, A., et. al., "Conceptual Design and Optimization of a $2^{\text {nd }}$ Generation PFB Combustion Plant", Phase 1 Task 1 Topical Report, DOE/MC/21023-285, (DE0000412), September 1989.

\subsection{Bibliography}

Not applicable 


\subsection{Acronyms and Abbreviations}

$\begin{array}{ll}\text { AFUDC } & \text { Allowance for Funds Used During Construction } \\ \text { AGR } & \text { Acid Gas Removal } \\ \text { ASU } & \text { Air Separation Unit } \\ \text { CFB } & \text { Circulating Fluidized Bed } \\ \text { CO } & \text { Carbon Monoxide } \\ \text { CO }_{2} & \text { Carbon Dioxide } \\ \text { COS } & \text { Carbonyl Sulfide } \\ \text { DOE } & \text { U.S. Department of Energy } \\ \text { EPRI } & \text { Electric Power Research Institute } \\ \text { ETE } & \text { Effective Thermal Efficiency } \\ \text { FW } & \text { Foster Wheeler Development Corporation } \\ \text { HCl } & \text { Hydrogen Chloride } \\ \text { HCN } & \text { Hydrogen Cyanide } \\ \text { HF } & \text { Hydrogen Fluoride } \\ \mathrm{H}_{2} & \text { Hydrogen } \\ \mathrm{H}_{2} \mathrm{~S} & \text { Hydrogen Sulfide } \\ \mathrm{HHV} & \text { Higher Heating Value } \\ \mathrm{HP} & \text { High Pressure } \\ \mathrm{HRSG} & \text { Heat Recovery Steam Generator } \\ \mathrm{HT} & \text { High Temperature } \\ \text { ID } & \text { Inside Diameter } \\ \text { IGCC } & \text { Integrated Gasification Combined Cycle } \\ \text { INTREX } & \text { Integrated Recycle Heat Exchanger } \\ \text { IP } & \text { Intermediate Pressure } \\ \text { LP } & \text { Low Pressure } \\ \text { LT } & \text { Low Temperature } \\ \text { NH } & \text { Ammonia } \\ \text { NOx } & \text { Oxides of Nitrogen } \\ \text { OJ } & \text { Operating Jobs } \\ \text { O\&M } & \text { Operating and Maintenance } \\ \text { Parsons } & \text { Parsons Infrastructure and Technology Group } \\ \text { PCFB } & \text { Pressurized Circulating Fluidized Bed } \\ \text { PGM } & \text { Partial Gasification Module } \\ \text { PSA } & \text { Pressure Swing Absorption } \\ \text { SMR } & \text { Steam Methane Reforming } \\ \text { SNCR } & \text { Selective Non Catalytic Reduction } \\ \text { SO } & \text { Sulfur Dioxide } \\ \text { TCR } & \text { Total Capital Requirement } \\ \text { TPC } & \text { Total Plant Cost } \\ \text { TPI } & \text { Total Plant Investment } \\ \text { US } & \text { United States } \\ & \end{array}$


$\underline{\text { Appendix A }}$

E-Gas Entrained Flow Gasifier Based Co-Production Plant with Spare Gasifier

A-1 
A1. List of Major Entrained Flow Co-Production Plant Equipment by Account

ACCOUNT 1 COAL RECEIVING AND HANDLING (serves entire plant)

Equipment Description

No.

$1 \quad$ Rotary Car Dumper and

Receiving Hoppers

2 Feeder

3 Conveyor 1

4 As-Received Coal

Sampling System

5 Conveyor 2

6 Reclaim Hopper

7 Stacker-Reclaimer

$8 \quad$ Feeder

9 Conveyor 3

10 Crusher Tower

11 Coal Surge Bin w/Vent

Filter

12 Crusher

13 Crusher

14 As-Fired Coal Sampling

System

15 Conveyor 4

16 Transfer Tower

17

18

Conveyor to Slurry Prep

Silos

Slurry Prep Silo w/Vent
Type

N/A

Vibratory

$54 "$ belt

Two-stage

$54 "$ belt

N/A

Vibratory

48 " belt

N/A

Compartment

Granulator reduction

Impactor reduction

Swing hammer

48 " belt

N/A

N/A

Filter and Slide Gates
Design Condition Qty.

100 ton

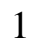

450 tph

2

900 tph 1

N/A

900 tph

100 ton

900 tph

200 tph

400 tph

400 tph

400 ton

400 tph

2

400 tph

2

2

400 tph

400 tph

400 tph

1500 ton

2 
ACCOUNT 2

COAL-WATER SLURRY PREPARATION AND FEED

(serves entire plant)

\begin{tabular}{|c|c|c|c|c|}
\hline$\frac{\text { Equipment }}{\underline{\text { No. }}}$ & $\underline{\text { Description }}$ & Type & $\underline{\text { Design Condition }}$ & Qty. \\
\hline 1 & Feeder & Vibrating & 200 tph & 2@100\% \\
\hline 2 & Rod Mill & Rotary & 200 tph & $2 @ 100 \%$ \\
\hline 3 & Surge Bin & Vertical, cylindrical & 800 tons & 1 \\
\hline 4 & Feeder & Weigh belt & 200 tph & $2 @ 100 \%$ \\
\hline 5 & Slurry Water Pumps & Centrifugal & 360 gpm @ $500 \mathrm{ft}$ & 2@100\% \\
\hline 6 & $\begin{array}{l}\text { Slurry Water Storage } \\
\text { Tank }\end{array}$ & Vertical & 40,000 gal & 1 \\
\hline 7 & Rod Mill Product Tank & Vertical & 52,000 gal & 2 \\
\hline 8 & Slurry Transfer Pumps & $\begin{array}{l}\text { Centrifugal, elastomer } \\
\text { lined or hard metal }\end{array}$ & 650 gpm @ 100ft & 4 \\
\hline 9 & $\begin{array}{l}\text { Slurry Storage Tank } \\
\text { with Agitator }\end{array}$ & Vertical & 120,000 gal (4 hrs) & 3 \\
\hline 10 & $\begin{array}{l}\text { Slurry Feed Pumps, } 1^{\text {st }} \\
\text { Stage }\end{array}$ & Progressing Cavity & 120 gpm @ 1,250 ft & $3 @ 50 \%$ \\
\hline 11 & $\begin{array}{l}\text { Slurry Feed Pumps, 2nd } \\
\text { Stage }\end{array}$ & Progressing Cavity & 315 gpm @ 1,250ft & $3 @ 50 \%$ \\
\hline 12 & LT Slurry Heater & Shell and tube & $29 \times 10^{6} \mathrm{Btu} / \mathrm{h}$ & 3 \\
\hline 13 & HT Slurry Heater & Shell and tube & $10 \times 10^{6} \mathrm{Btu} / \mathrm{h}$ & 3 \\
\hline
\end{tabular}

\section{ACCOUNT 3 FEEDWATER AND MISCELLANEOUS BOP SYSTEMS}

\section{ACCOUNT 3A-1 CONDENSATE AND FEEDWATER SYSTEM-POWER TRAIN}

\begin{tabular}{|c|c|c|c|c|}
\hline$\frac{\text { Equipment }}{\text { No. }}$ & $\underline{\text { Description }}$ & Type & Design Condition & Qty \\
\hline 1 & $\begin{array}{l}\text { Condensate. Storage } \\
\text { Tank }\end{array}$ & $\begin{array}{l}\text { Vertical, cylindrical, } \\
\text { outdoor }\end{array}$ & 200,000 gal & 1 \\
\hline 2 & Condensate Pumps & Vertical canned & $1,100 \mathrm{gpm} @ 400 \mathrm{ft}$ & 2@100\% \\
\hline 3 & Deaerator & Horizontal spray type & $\begin{array}{l}650,000 \mathrm{lb} / \mathrm{h} \\
205^{\circ} \mathrm{F} \text { to } 240^{\circ} \mathrm{F}\end{array}$ & 1 \\
\hline 4 & LP Feed Pump & $\begin{array}{l}\text { Horizontal centrifugal } \\
\text { single stage }\end{array}$ & $400 \mathrm{gpm} / 400 \mathrm{ft}$ & $2 @ 100 \%$ \\
\hline 5 & HP Feed Pump & $\begin{array}{l}\text { Ring-segment type, } \\
\text { multi-staged, centrifugal. }\end{array}$ & 1,250 gpm @ $4800 \mathrm{ft}$ & 2@100\% \\
\hline
\end{tabular}


ACCOUNT 3A-2 CONDENSATE AND FEEDWATER SYSTEM-H H $_{2}$ TRAIN

\begin{tabular}{|c|c|c|c|c|}
\hline$\frac{\text { Equipment }}{\underline{\text { No. }}}$ & $\underline{\text { Description }}$ & $\underline{\text { Type }}$ & Design Condition & Qty \\
\hline 1 & $\begin{array}{l}\text { Condensate. Storage } \\
\text { Tank }\end{array}$ & $\begin{array}{l}\text { Vertical, cylindrical, } \\
\text { outdoor }\end{array}$ & 200,000 gal & 1 \\
\hline 2 & Condensate Pumps & Vertical canned & 1,200 gpm @ $400 \mathrm{ft}$ & 2@100\% \\
\hline 3 & Deaerator & Horizontal spray type & $\begin{array}{l}650,000 \mathrm{lb} / \mathrm{h} \\
205^{\circ} \mathrm{F} \text { to } 240^{\circ} \mathrm{F}\end{array}$ & 1 \\
\hline 4 & LP Feed Pump & $\begin{array}{l}\text { Horizontal centrifugal } \\
\text { single stage }\end{array}$ & $400 \mathrm{gpm} / 400 \mathrm{ft}$ & $2 @ 100 \%$ \\
\hline 5 & HP Feed Pump & $\begin{array}{l}\text { Ring-segment type, multi- } \\
\text { stage, centrifugal. }\end{array}$ & 1,250 gpm @ 4,000 ft & $2 @ 100 \%$ \\
\hline
\end{tabular}




\section{ACCOUNT 3B MISCELLANEOUS EQUIPMENT (serves entire plant)}

\begin{tabular}{|c|c|c|c|c|}
\hline$\frac{\text { Equipment }}{\text { No. }}$ & $\underline{\text { Description }}$ & Type & $\underline{\text { Design Condition }}$ & Qty \\
\hline 1 & Auxiliary Boiler & $\begin{array}{l}\text { Shop fabricated, water } \\
\text { tube }\end{array}$ & $\begin{array}{l}400 \mathrm{psig}, 650^{\circ} \mathrm{F} \\
70,000 \mathrm{lb} / \mathrm{h}\end{array}$ & 1 \\
\hline 2 & Service Air Compressors & $\begin{array}{l}\text { Reciprocating, single } \\
\text { stage, double acting, } \\
\text { horizontal }\end{array}$ & 100 psig, $750 \mathrm{cfm}$ & 2 \\
\hline 3 & Inst. Air Dryers & Duplex, regenerative & $750 \mathrm{cfm}$ & 1 \\
\hline 4 & Service Water Pumps & $\begin{array}{l}\text { Horizontal centrifugal, } \\
\text { double suction }\end{array}$ & $200 \mathrm{ft}, 1,200 \mathrm{gpm}$ & 2 \\
\hline 5 & $\begin{array}{l}\text { Closed Cycle Cooling } \\
\text { Water Pumps }\end{array}$ & Horizontal, centrifugal & $70 \mathrm{ft}, 1,200 \mathrm{gpm}$ & 2 \\
\hline 6 & $\begin{array}{l}\text { Fire Service Booster } \\
\text { Pump }\end{array}$ & $\begin{array}{l}\text { Two-stage horizontal } \\
\text { centrifugal }\end{array}$ & $250 \mathrm{ft}, 1,200 \mathrm{gpm}$ & 1 \\
\hline 7 & Engine-Driven Fire Pump & $\begin{array}{l}\text { Vertical turbine, diesel } \\
\text { engine }\end{array}$ & $350 \mathrm{ft}, 1,000 \mathrm{gpm}$ & 1 \\
\hline 8 & Trash Rack/Rake & & & 1 \\
\hline 9 & Traveling Screen & & & 1 \\
\hline 10 & Screen Wash Pump & & & 2 \\
\hline 11 & Clarifier & & $3,500 \mathrm{gpm}$ & 1 \\
\hline 12 & Chemical Feed Skid & & & 1 \\
\hline 13 & Filter & & $3,500 \mathrm{gpm}$ & 1 \\
\hline 14 & Raw Water Pumps & SS, single suction & $60 \mathrm{ft}, 3,500 \mathrm{gpm}$ & 2 \\
\hline 15 & Filtered Water Pumps & $\mathrm{SS}$, single suction & $160 \mathrm{ft}, 35100 \mathrm{gpm}$ & 2 \\
\hline 16 & Filtered Water Tank & Vertical, cylindrical & $1,000,000 \mathrm{gal}$ & 1 \\
\hline 17 & $\begin{array}{l}\text { Steam Cycle Makeup } \\
\text { Demineralizer }\end{array}$ & Reverse Osmosis Unit & $440 \mathrm{gpm}$ & 1 \\
\hline 18 & Chemical Feed Skid & & & 1 \\
\hline 19 & $\begin{array}{l}\text { Steam Cycle Makeup } \\
\text { Polisher }\end{array}$ & Electro Dialysis Unit & $440 \mathrm{gpm}$ & 1 \\
\hline 20 & $\begin{array}{l}\text { Sour Water Stripper } \\
\text { System }\end{array}$ & Vendor supplied & $\begin{array}{l}205,000 \mathrm{lb} / \mathrm{h} \text { sour } \\
\text { water }\end{array}$ & 1 \\
\hline 21 & $\begin{array}{l}\text { Liquid Waste Treatment } \\
\text { System }\end{array}$ & Vendor supplied & 60 gpm & 1 \\
\hline
\end{tabular}




\section{ACCOUNT 4 GASIFIER AND ACCESSORIES}

\section{ACCOUNT 4A GASIFICATION}

(3 gasifier trains provided, one each for $\mathrm{H}_{2}$ and power trains, one swing spare)

\begin{tabular}{|c|c|c|c|}
\hline$\frac{\text { Equipment }}{\underline{\text { No. }}}$ & $\underline{\text { Description }}$ & Type & $\underline{\text { Design Condition }}$ \\
\hline 1 & $\begin{array}{l}\text { Gasifier, including char } \\
\text { recycle and slag } \\
\text { depressurizing and } \\
\text { dewatering system }\end{array}$ & $\begin{array}{l}\text { Pressurized entrained } \\
\text { bed/syngas cooler }\end{array}$ & $\begin{array}{l}2,250 \text { std (dry-coal } \\
\text { basis) @ } 515 \text { psia }\end{array}$ \\
\hline 2 & $\begin{array}{l}\text { Raw Gas Cooler Steam } \\
\text { Generator }\end{array}$ & Fire tube boiler & $\begin{array}{l}1,800 \mathrm{psig} / 621^{\circ} \mathrm{F} \\
466 \mathrm{MMBtu} / \mathrm{h}\end{array}$ \\
\hline 3 & Cyclone & $\begin{array}{l}\text { Carbon steel, abrasion } \\
\text { resistant liner }\end{array}$ & 500 psia, $700 \mathrm{~F}$ \\
\hline 5 & $\begin{array}{l}\text { Medium-Temperature } \\
\text { Candle Filter with Back } \\
\text { Pulse Candle Cleaning } \\
\text { Skid }\end{array}$ & $\begin{array}{l}\text { Sintered stainless candle, } \\
\text { carbon steel vessel }\end{array}$ & $484 \mathrm{psia}, 690^{\circ} \mathrm{F}$ \\
\hline 6 & $\begin{array}{l}\text { Syngas Recycle } \\
\text { Compressor }\end{array}$ & Centrifugal & $99,000 \mathrm{lb} / \mathrm{hr} . \mathrm{PR}=1.35: 1$ \\
\hline 7 & Flare Stack & $\begin{array}{l}\text { Self-supporting, carbon } \\
\text { steel, stainless steel top, } \\
\text { pilot ignition }\end{array}$ & $\begin{array}{l}420,000 \mathrm{lb} / \mathrm{h} \text {, medium- } \\
\text { Btu gas }\end{array}$ \\
\hline
\end{tabular}

\section{ACCOUNT 4B AIR SEPARATION PLANT (serves entire plant, 2 trains at $50 \%$ capacity)}

\begin{tabular}{|c|c|c|c|}
\hline$\frac{\text { Equipment }}{\underline{\text { No. }}}$ & $\underline{\text { Description }}$ & Type & $\underline{\text { Design Condition }}$ \\
\hline 1 & Air Compressor & Centrifugal, multi-stage & $\begin{array}{l}\text { 144,000 scfm, } 70 \text { psia } \\
\text { discharge pressure }\end{array}$ \\
\hline 2 & Cold Box & Vendor supplied & 1,750 ton/day $\mathrm{O}_{2}$ \\
\hline 3 & Oxygen Compressor & Centrifugal, multi-stage & $\begin{array}{l}29,000 \mathrm{scfm}, 800 \mathrm{psig} \\
\text { discharge pressure }\end{array}$ \\
\hline 4 & $\begin{array}{l}\text { Liquid Oxygen Storage } \\
\text { Tank }\end{array}$ & Vertical & $60^{\prime}$ dia. $x$ 80' vert \\
\hline 5 & $\begin{array}{l}\text { DeNOx Nitrogen } \\
\text { Compressor }\end{array}$ & Centrifugal, multi-stage & $\begin{array}{l}\text { 110,000 scfm, } 344 \text { psig } \\
\text { discharge pressure }\end{array}$ \\
\hline 6 & $\begin{array}{l}\text { Gasifier Nitrogen } \\
\text { Compressor }\end{array}$ & Centrifugal, multi-stage & $1,750 \mathrm{scfm}$ at $525 \mathrm{psig}$ \\
\hline
\end{tabular}




\section{ACCOUNT 5 SYNGAS SHIFT AND CLEANUP}

\section{ACCOUNT 5A WATER-GAS SHIFT AND RAW GAS COOLING}

\section{ACCOUNT 5A-1 H2 PRODUCTION TRAIN}

\section{$\underline{\text { Equipment Description }}$}

No.

High Temperature Shift

Reactor No. 1

High Temperature Shift

Reactor No. 2

$3 \quad$ Low Temperature Shift

Reactor

4

HP Steam Generator No. Shell and tube 1

5

HP Steam Generator No. Shell and tube 2

6

7

8

Syngas Gas to gas
Reheater

9 Raw Gas Coolers

10 Raw Gas Knock Out Drum

11 Raw Syngas Steam Generator

12 Syngas Water Scrubber

13 Scrubber Reflux Cooler

14 Sour Water Collection Tank

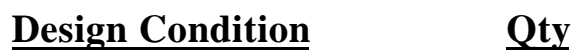

Fixed bed

$500 \mathrm{psia}, 750^{\circ} \mathrm{F}, 266 \mathrm{cu} \mathrm{ft}$ of $\quad 1$ catalyst

$500 \mathrm{psia}, 622^{\circ} \mathrm{F}, 261 \mathrm{cu} \mathrm{ft}$ of $\quad 1$ catalyst

$500 \mathrm{psia}, 450^{\circ} \mathrm{F} 230 \mathrm{cu} \mathrm{ft}$ of $\quad 1$

catalyst

$70 \times 10^{6} \mathrm{Btu} / \mathrm{h} @ 1700 \mathrm{psia} 1$ and $613^{\circ} \mathrm{F}$

$70 \times 10^{6} \mathrm{Btu} / \mathrm{h} @ 1700 \mathrm{psia} 1$ and $613^{\circ} \mathrm{F}$

45 x 106 Btu/h@ 400 psia 1 and $450^{\circ} \mathrm{F}$

$20 \times 10^{6}$ Btu/h@200psia 1 and $382^{\circ} \mathrm{F}$

Shell and Tube

$33 \times 10^{6} \mathrm{Btu} / \mathrm{hr}$

Shell $448 \mathrm{psia} / 550 \mathrm{~F}$

Tube: $433 \mathrm{psia} / 537 \mathrm{~F}$

Shell and tube with

$150 \times 10^{6} \mathrm{Btu} / \mathrm{h}$

2 condensate drain

$400 \mathrm{psia}, 130^{\circ} \mathrm{F}$

1 eliminator

Shell and Tube

400 psia, 690F

1

474 psia, 330F 1

Shell and Tube

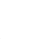

1

1

1 1

(1)


ACCOUNT 5 SYNGAS SHIFT AND CLEANUP

ACCOUNT 5A WATER-GAS SHIFT AND RAW GAS COOLING

ACCOUNT 5A-2 POWER TRAIN

\begin{tabular}{|c|c|c|c|c|}
\hline$\frac{\text { Equipment }}{\underline{\text { No. }}}$ & $\underline{\text { Description }}$ & Type & $\underline{\text { Design Condition }}$ & Qty \\
\hline 1 & Syngas Reheater (gas/gas) & Shell and Tube & $500 \mathrm{psig} / 700 \mathrm{~F}$ & 1 \\
\hline 2 & COS Hydrolysis Reactor & Packed Column & $450 \mathrm{psig} / 400 \mathrm{~F}$ & 1 \\
\hline 3 & Saturator Hot Water Heater & Shell and Tube & $500 \mathrm{psig} / 620 \mathrm{~F}$ & 1 \\
\hline 4 & Syngas Water Scrubber & Tray & $450 \mathrm{psig} / 330 \mathrm{~F}$ & 1 \\
\hline 5 & Scrubber Reflux Cooler & Shell and Tube & $450 \mathrm{psig} / 330 \mathrm{~F}$ & 1 \\
\hline 6 & Raw Gas Coolers & Shell and Tube & & 3 \\
\hline 7 & Knockout Drum & & & 1 \\
\hline 8 & Sour Gas Stripper & Column & & 1 \\
\hline 9 & Stripper Reflux Heater & Shell and Tube & & 1 \\
\hline
\end{tabular}

\section{ACCOUNT 5B ACID GAS REMOVAL AND GAS CONDITIONING}

\section{ACCOUNT 5B-1 $\mathrm{H}_{2}$ PRODUCTION TRAIN}

\section{Equipment Description}

No.

1

2

3
Amine Absorber A1

Sulfur Plant

PSA Unit
Type

Column

Vendor design

Fixed bed

\section{$\underline{\text { Design Condition }}$}

$133,000 \operatorname{scfm}(6,500$ acfm), 390 psia, $103^{\circ} \mathrm{F}$

127 tpd elemental sulfur $341,522 \mathrm{lb} /$ he syngas for $101 \mathrm{MMscfd} \mathrm{H}_{2} @$ 370 psia

Qty

ACCOUNT 5B-2 POWER TRAIN

$\underline{\text { Equipment Description }}$

Type

$\underline{\text { Design Condition }}$

Qty

No.

1 Amine Absorber A2

Column

94,000 scfm (4,600 acfm), 413 psia, $103^{\circ} \mathrm{F}$

2 Fuel Gas Saturator

Column

445 psia, $325 \mathrm{~F}$

Shell and Tube

395 psia, $535 \mathrm{~F}$

1 1 1 
ACCOUNT 5C SULFUR RECOVERY and TAIL GAS RECYCLE

\begin{tabular}{|c|c|c|c|c|}
\hline$\frac{\text { Equipment }}{\underline{\text { No. }}}$ & $\underline{\text { Description }}$ & Type & $\underline{\text { Design Condition }}$ & Qty \\
\hline 1 & Claus Furnace & & & 1 \\
\hline 2 & Converter Preheater & & & 2 \\
\hline 3 & Sulfur Converter & & & 2 \\
\hline 4 & Sulfur Condenser & & 43 tpd & 3 \\
\hline 5 & $\begin{array}{l}\text { Hydrogenation Reactor } \\
\text { Preheater }\end{array}$ & & & 1 \\
\hline 6 & Hydrogenation Reactor & & & 1 \\
\hline 7 & Contact Cooler & & & 1 \\
\hline 8 & Tail Gas Recycle Comp. & $\begin{array}{l}\text { Centrifugal, inter- } \\
\text { cooled }\end{array}$ & 46,333 lb/hr, Pr 45:1 & $2 @ 100 \%$ \\
\hline 9 & $\begin{array}{l}\text { Regenerator for Amine } \\
\text { Absorbers A1 and A2 }\end{array}$ & Column & $183,372 \mathrm{lb} / \mathrm{hr}$ gas release & 1 \\
\hline 10 & Acid Gas Concentrator & & Twin column & 1 \\
\hline 11 & $\mathrm{H}_{2} \mathrm{~S}$ Preheater & Shell and Tube & & 1 \\
\hline 12 & Oxygen Preheater & Shell and Tube & & 1 \\
\hline 13 & Stripper Gas Preheater & Shell and Tube & & 1 \\
\hline
\end{tabular}

\begin{tabular}{|c|c|c|c|c|}
\hline ACCOUNT & COMBUSTION & RBINE/and ACCI & SORIES-POWER TR & ONL \\
\hline$\frac{\text { Equipment }}{\underline{\text { No. }}}$ & $\underline{\text { Description }}$ & Type & $\frac{\text { Design Condition }}{\text { Drums }}$ & Qty \\
\hline 1 & $\begin{array}{l}\text { GE 7FA Combustion } \\
\text { Turbine Generator }\end{array}$ & $\begin{array}{l}\text { Frame Type, } \\
\text { Syngas Fired }\end{array}$ & $\begin{array}{l}197 \text { MWe at ISO } \\
\text { Conditions firing syngas }\end{array}$ & 1 \\
\hline 2 & $\begin{array}{l}\text { Heat Recovery Steam } \\
\text { Generator }\end{array}$ & $\begin{array}{l}\text { Unfired, Two } \\
\text { Drum, Reheater }\end{array}$ & $\begin{array}{l}589,000 \mathrm{lb} / \mathrm{h} \text { superheated } \\
\text { steam at } 1685 \\
\text { psig/1005F }\end{array}$ & 1 \\
\hline & & & $\begin{array}{l}564,482 \mathrm{lb} / \mathrm{hr} \text { reheat } \\
\text { steam at } 370 \mathrm{psig} / 1005 \mathrm{~F}\end{array}$ & \\
\hline 3 & Stack & $\begin{array}{l}\text { Carbon steel plate, } \\
\text { type } 409 \text { stainless } \\
\text { steel liner }\end{array}$ & $213 \mathrm{ft}$ high $\times 24 \mathrm{ft}$ dia. & 1 \\
\hline
\end{tabular}


ACCOUNT 7 FIRED BOILER AND STACK-H 2 PRODUCTION TRAIN ONLY

\begin{tabular}{|c|c|c|c|}
\hline$\frac{\text { Equipment }}{\underline{\text { No. }}}$ & $\underline{\text { Description }}$ & Type & $\frac{\text { Design Condition }}{\text { Drums }}$ \\
\hline 1 & Fired Steam Generator & $\begin{array}{l}\text { Drum Type, Forced } \\
\text { Draft with } 2000 \text { hp FD } \\
\text { fan }\end{array}$ & $\begin{array}{l}408,000 \mathrm{lb} / \mathrm{h} \text { superheated } \\
\text { steam at } 1275 \\
\text { psig/ } 955^{\circ} \mathrm{F}\end{array}$ \\
\hline 2 & Stack & $\begin{array}{l}\text { Carbon steel plate, type, } \\
409 \text { stainless steel liner }\end{array}$ & $213 \mathrm{ft}$ high x $12 \mathrm{ft}$ dia. \\
\hline
\end{tabular}

\section{ACCOUNT 8 STEAM TURBINE GENERATOR AND AUXILIARIES}

\section{ACCOUNT 8-1 H HODUCTION TRAIN}

\begin{tabular}{|c|c|c|c|c|}
\hline$\frac{\text { Equipment }}{\underline{\text { No. }}}$ & $\underline{\text { Description }}$ & Type & $\frac{\text { Design Condition }}{\text { (per each) }}$ & Qty \\
\hline 1 & $\begin{array}{l}50 \text { MW Steam Turbine } \\
\text { Generator }\end{array}$ & $\begin{array}{l}\text { Non-Reheat, TC1F26, } \\
\text { Axial Exhaust, } \\
\text { TEWAC Generator }\end{array}$ & $1275 \mathrm{psig} / 955^{\circ} \mathrm{F}$ & 1 \\
\hline 2 & $\begin{array}{l}\text { Bearing Lube Oil } \\
\text { Coolers }\end{array}$ & Plate and frame & & 2 \\
\hline 3 & $\begin{array}{l}\text { Bearing Lube Oil } \\
\text { Conditioner }\end{array}$ & $\begin{array}{l}\text { Pressure filter closed } \\
\text { loop }\end{array}$ & & 1 \\
\hline 4 & Control System & $\begin{array}{l}\text { Digital electro- } \\
\text { hydraulic }\end{array}$ & & 1 \\
\hline 5 & Generator Coolers & Plate and frame & & 2 \\
\hline 6 & & & & 1 \\
\hline 7 & Surface Condenser & $\begin{array}{l}\text { Single pass, divided } \\
\text { waterbox }\end{array}$ & $\begin{array}{l}530 \mathrm{MM} \mathrm{Btu} / \mathrm{h}, 2.0 \text { in } \\
\mathrm{Hga}\end{array}$ & 1 \\
\hline 8 & $\begin{array}{l}\text { Condenser Vacuum } \\
\text { Pumps }\end{array}$ & Rotary, water sealed & $\begin{array}{l}\text { 2500/25 scfm } \\
\text { (hogging/holding) }\end{array}$ & 2 \\
\hline
\end{tabular}


ACCOUNT 8-2 POWER TRAIN

\begin{tabular}{|c|c|c|c|}
\hline$\frac{\text { Equipment }}{\underline{\text { No. }}}$ & Description & Type & $\frac{\text { Design Condition }}{\text { (per each) }}$ \\
\hline 1 & $\begin{array}{l}100 \text { MW Steam Turbine } \\
\text { Generator }\end{array}$ & $\begin{array}{l}\text { Reheat, TC1F33.5, Axial } \\
\text { Exhaust, TEWAC } \\
\text { Generator }\end{array}$ & $\begin{array}{l}1600 \\
\mathrm{psig} / 1000 \mathrm{~F} / 1000^{\circ} \mathrm{F}\end{array}$ \\
\hline 2 & Bearing Lube Oil Coolers & Plate and frame & \\
\hline 3 & $\begin{array}{l}\text { Bearing Lube Oil } \\
\text { Conditioner }\end{array}$ & Pressure filter closed loop & \\
\hline 4 & Control System & Digital electro-hydraulic & \\
\hline 5 & Generator Coolers & Plate and frame & \\
\hline 6 & & & \\
\hline 7 & Surface Condenser & $\begin{array}{l}\text { Single pass, divided } \\
\text { waterbox }\end{array}$ & $\begin{array}{l}500 \mathrm{MM} \mathrm{Btu} / \mathrm{h}, 2.0 \text { in } \\
\mathrm{Hga}\end{array}$ \\
\hline 8 & $\begin{array}{l}\text { Condenser Vacuum } \\
\text { Pumps }\end{array}$ & Rotary, water sealed & $\begin{array}{l}\text { 2500/25 scfm } \\
\text { (hogging/holding) }\end{array}$ \\
\hline
\end{tabular}

\begin{tabular}{|c|c|c|c|c|}
\hline \multicolumn{5}{|c|}{ ACCOUNT $9 \quad$ COOLING WATER SYSTEM (serves both $\mathrm{H}_{2}$ and Power Trains) } \\
\hline$\frac{\text { Equipment }}{\text { No. }}$ & Description & $\underline{\text { Type }}$ & $\frac{\text { Design Condition }}{\text { (per each) }}$ & Qty \\
\hline 1 & Circ. Water Pumps & Vertical wet pit & $\begin{array}{l}48,000 \text { gpm @ } 60 \mathrm{ft} \\
\text { TDH }\end{array}$ & $\begin{array}{l}3 @ \\
50 \%\end{array}$ \\
\hline 2 & Cooling Tower & $\begin{array}{l}\text { Mechanical draft, multi- } \\
\text { cell, } 19 \mathrm{~F} \text { Approach/21F } \\
\text { Range at 53F WB }\end{array}$ & 96,000 gpm & 1 \\
\hline
\end{tabular}

\section{ACCOUNT 10 ASH/SPENT SORBENT RECOVERY AND HANDLING}

ACCOUNT 10A SLAG DEWATERING AND REMOVAL

\section{$\underline{\text { Equipment } \text { Description }}$}

No.

1 Slag Dewatering System

2 Slag Conveyor

3 Slag Conveyor

4 Bucket Elevator

$5 \quad$ Slag Silo

6 Truck Unloader
Type

Vendor proprietary

Drag Chain

Drag Chain

Vertical, cylindrical, bolted steel

Telescoping Chute

\section{$\underline{\text { Design Condition } \quad \text { Qty }}$}

230 tpd

3

10 tph

20 tph

20 tph

1400 tons

60 tph
3

2

2

1

2 


\section{A2. Total Plant Cost Estimate}

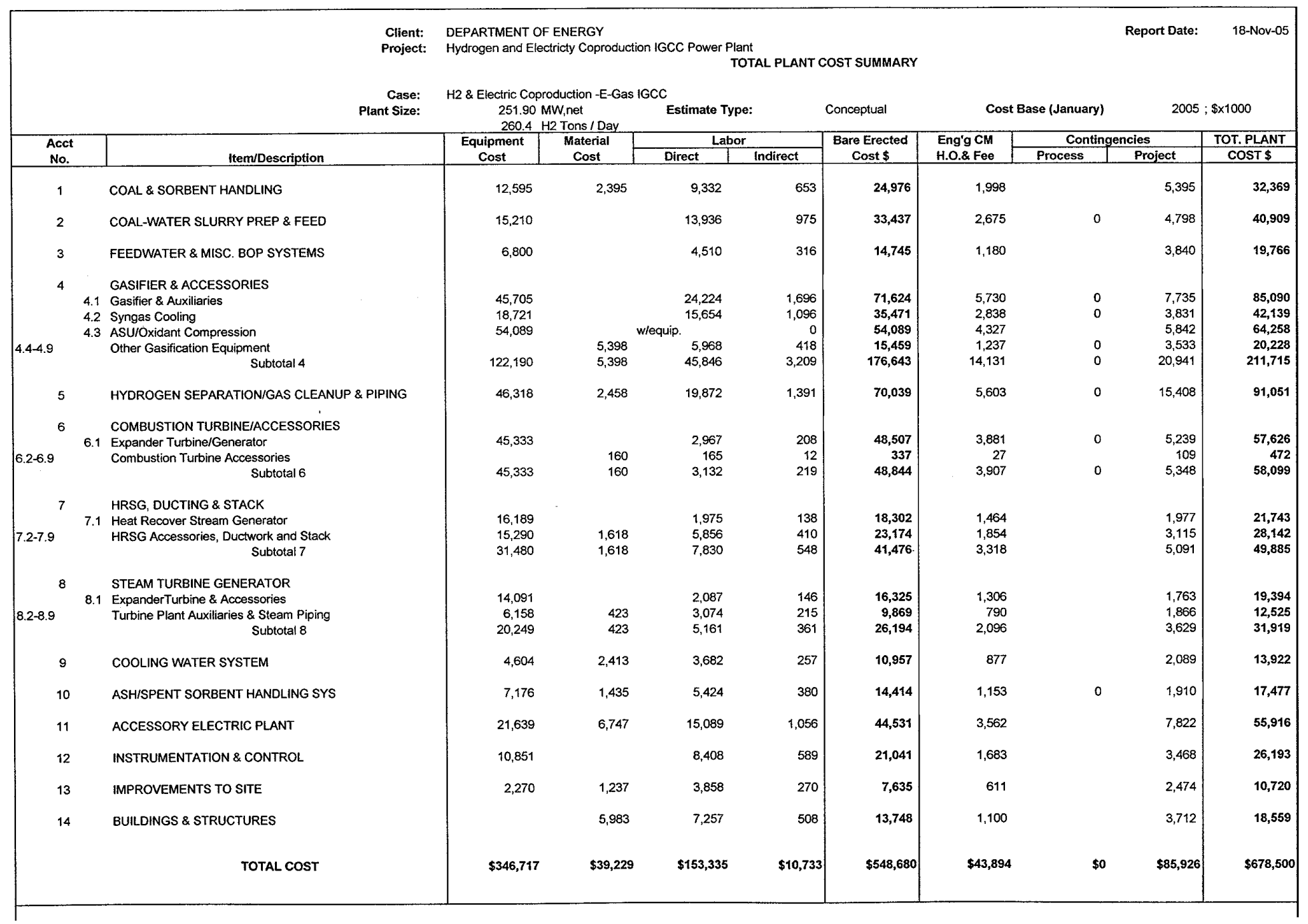




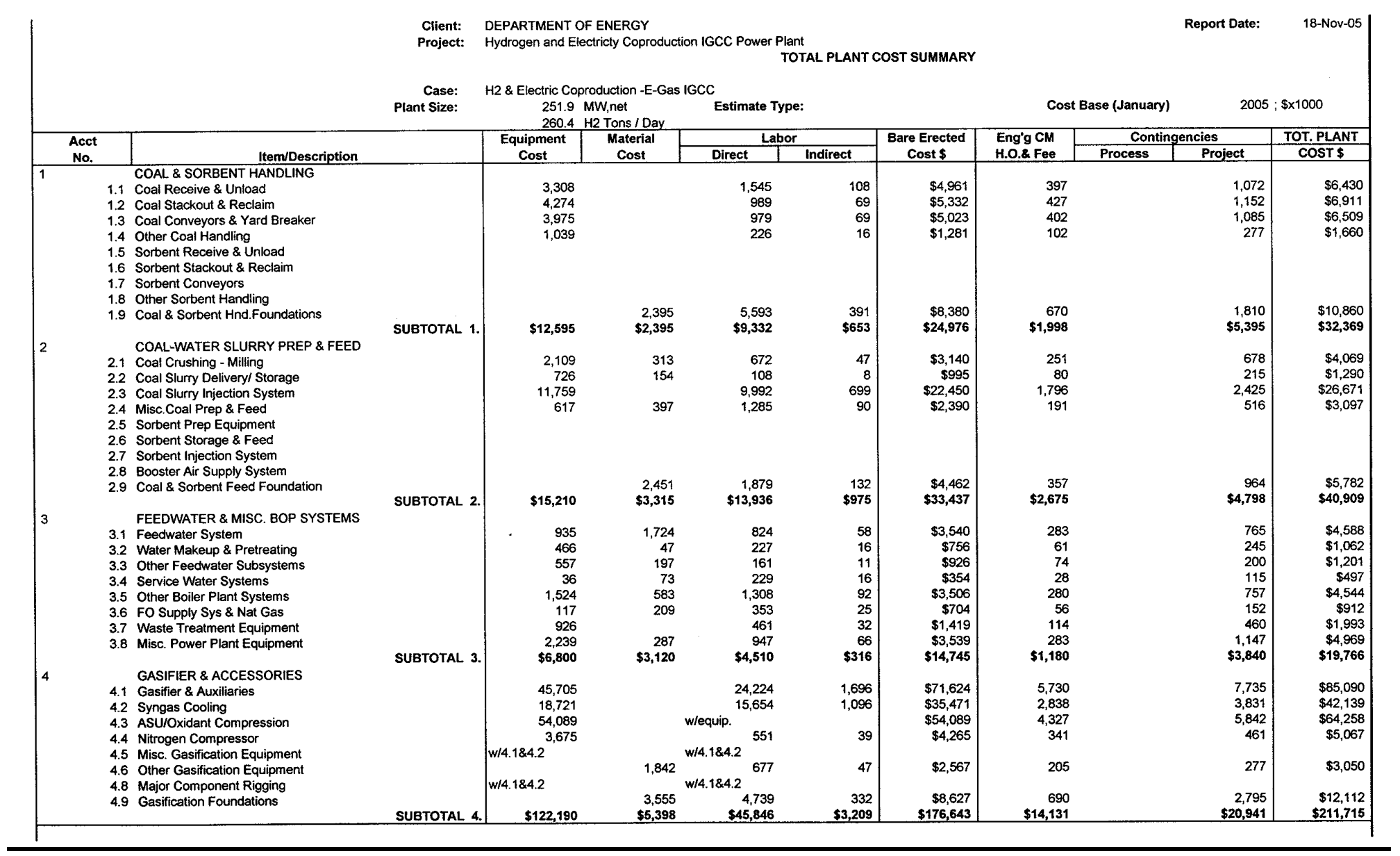




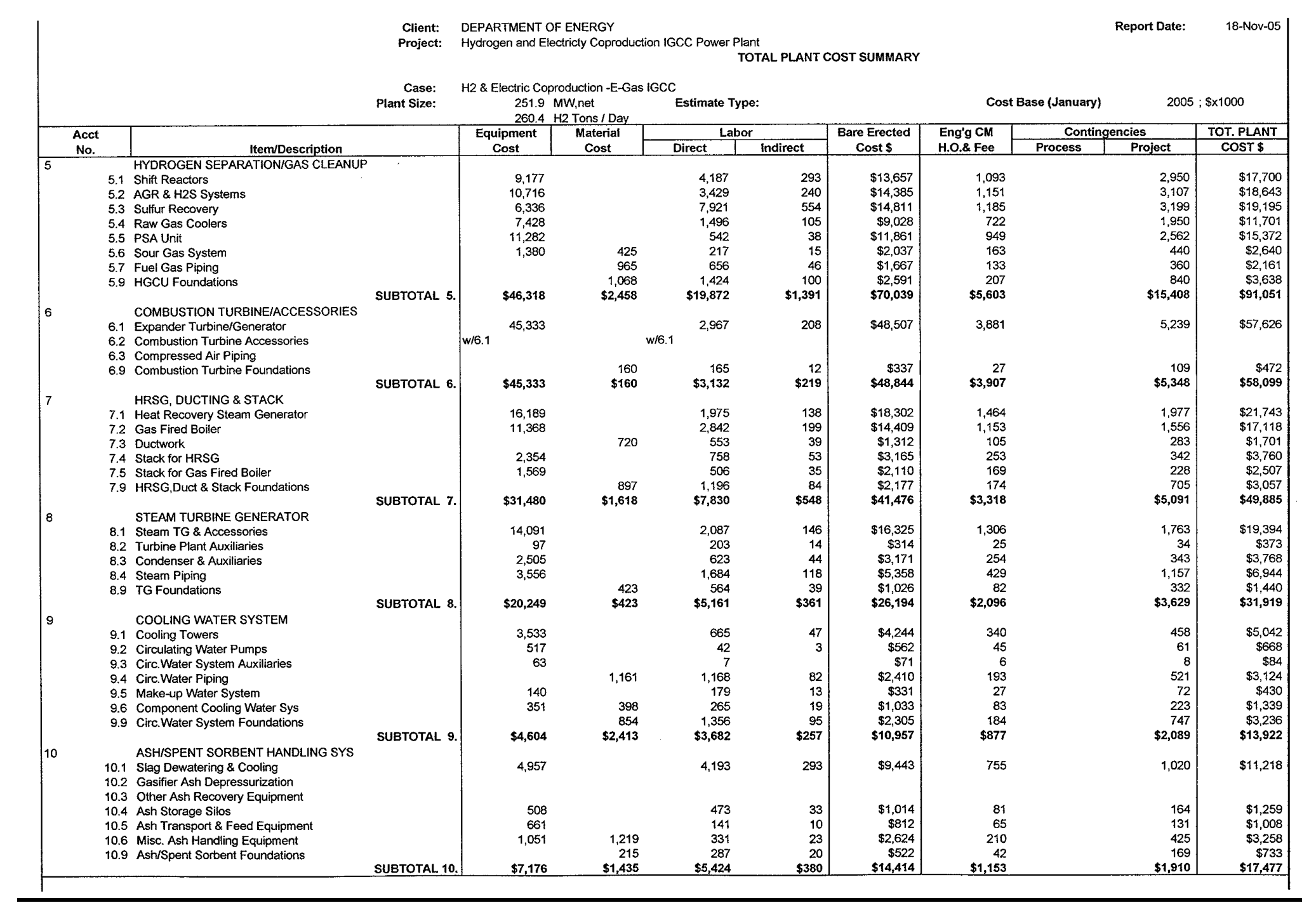




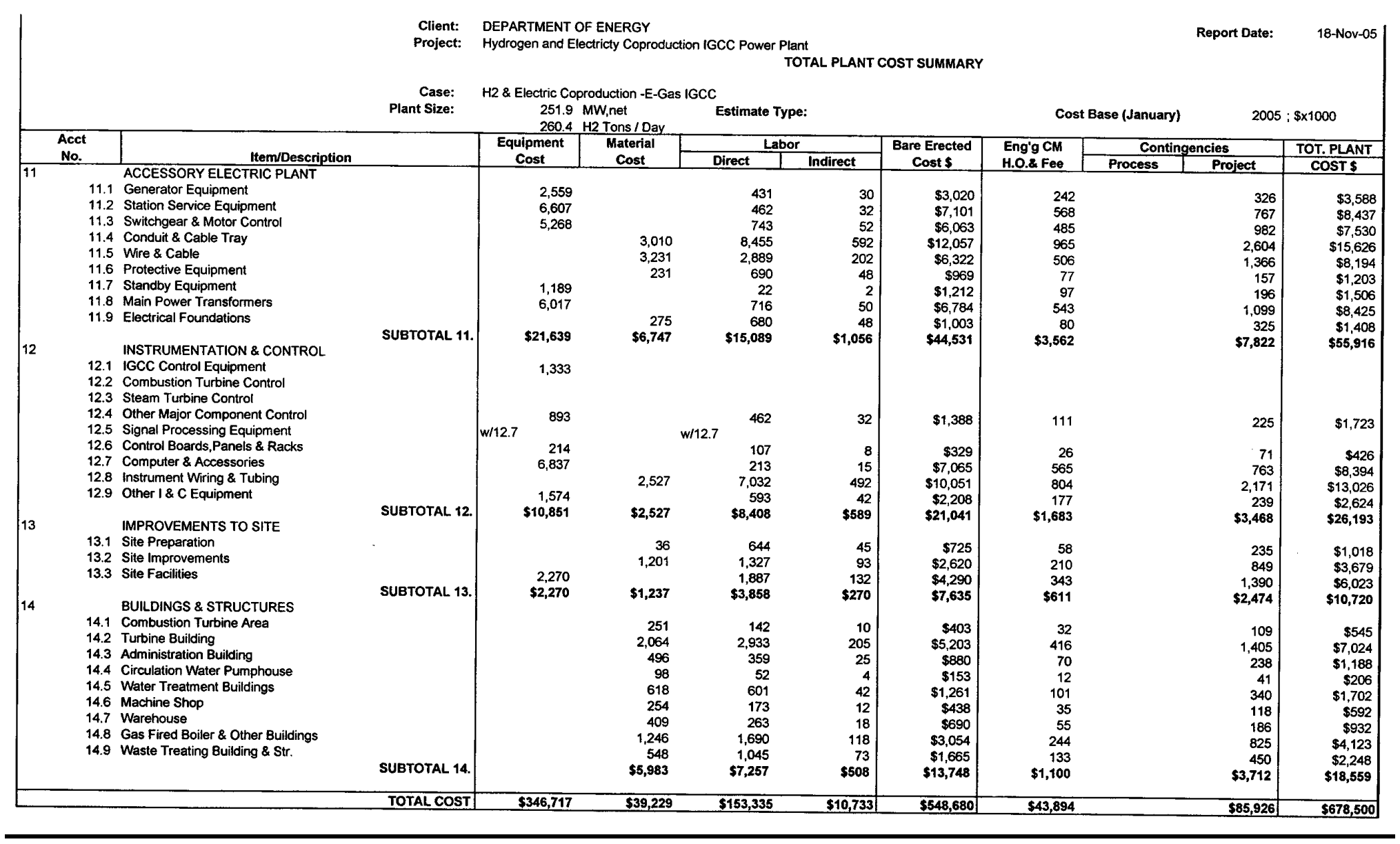


$\underline{\text { Appendix B }}$

E-Gas Entrained Flow Gasifier Based Co-Production Plant without Spare Gasifier 


\section{B1. Total Plant Cost Estimate}

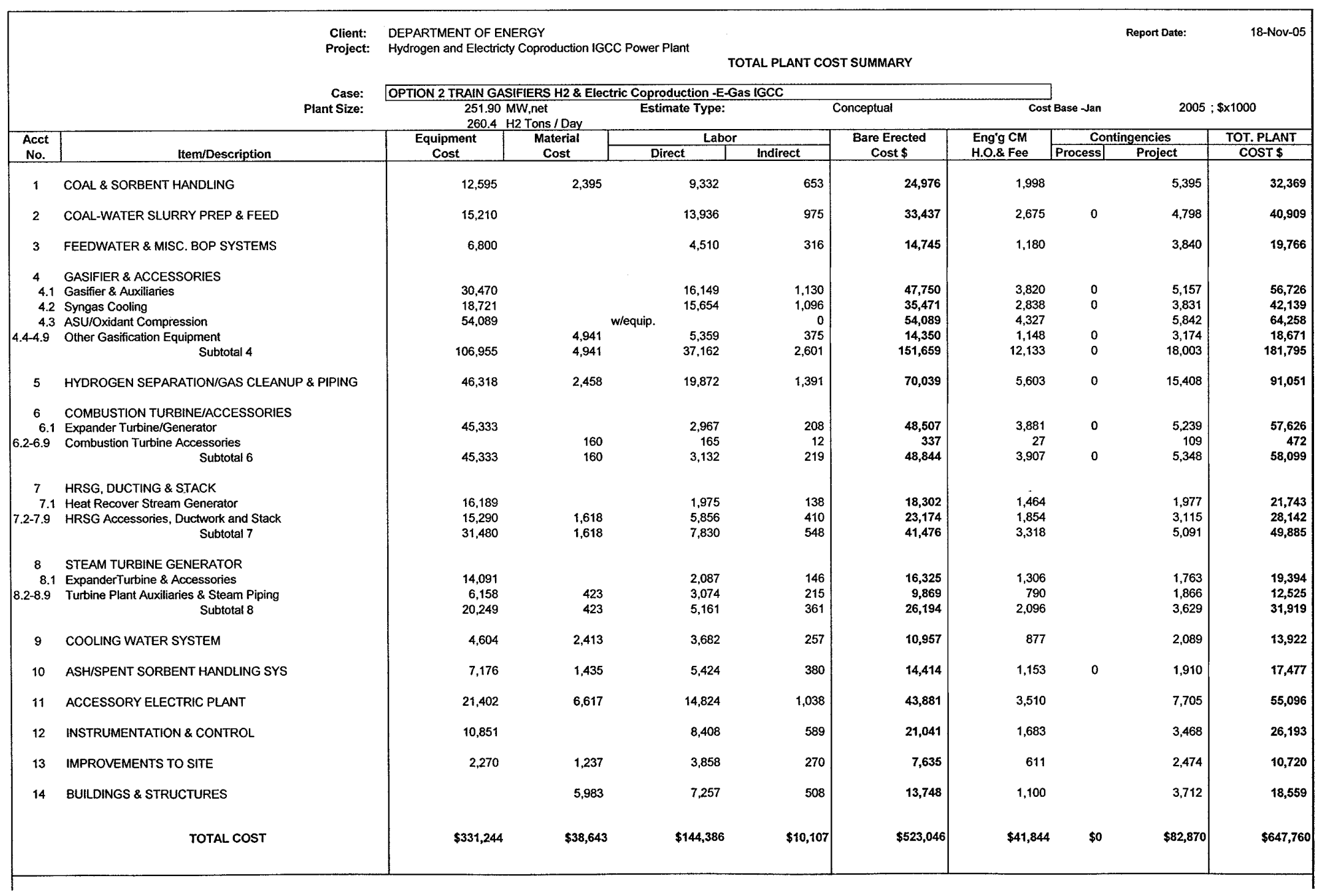




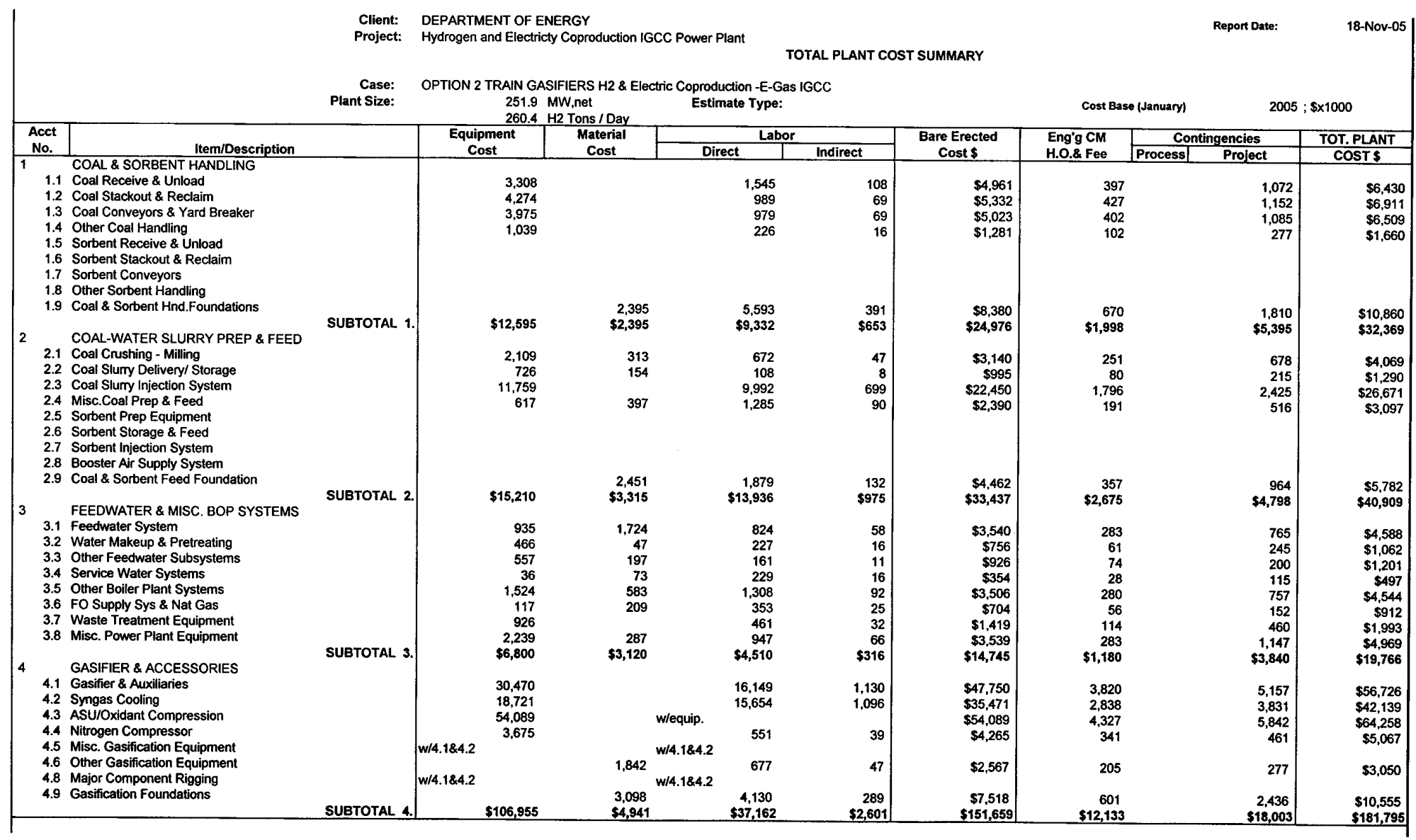




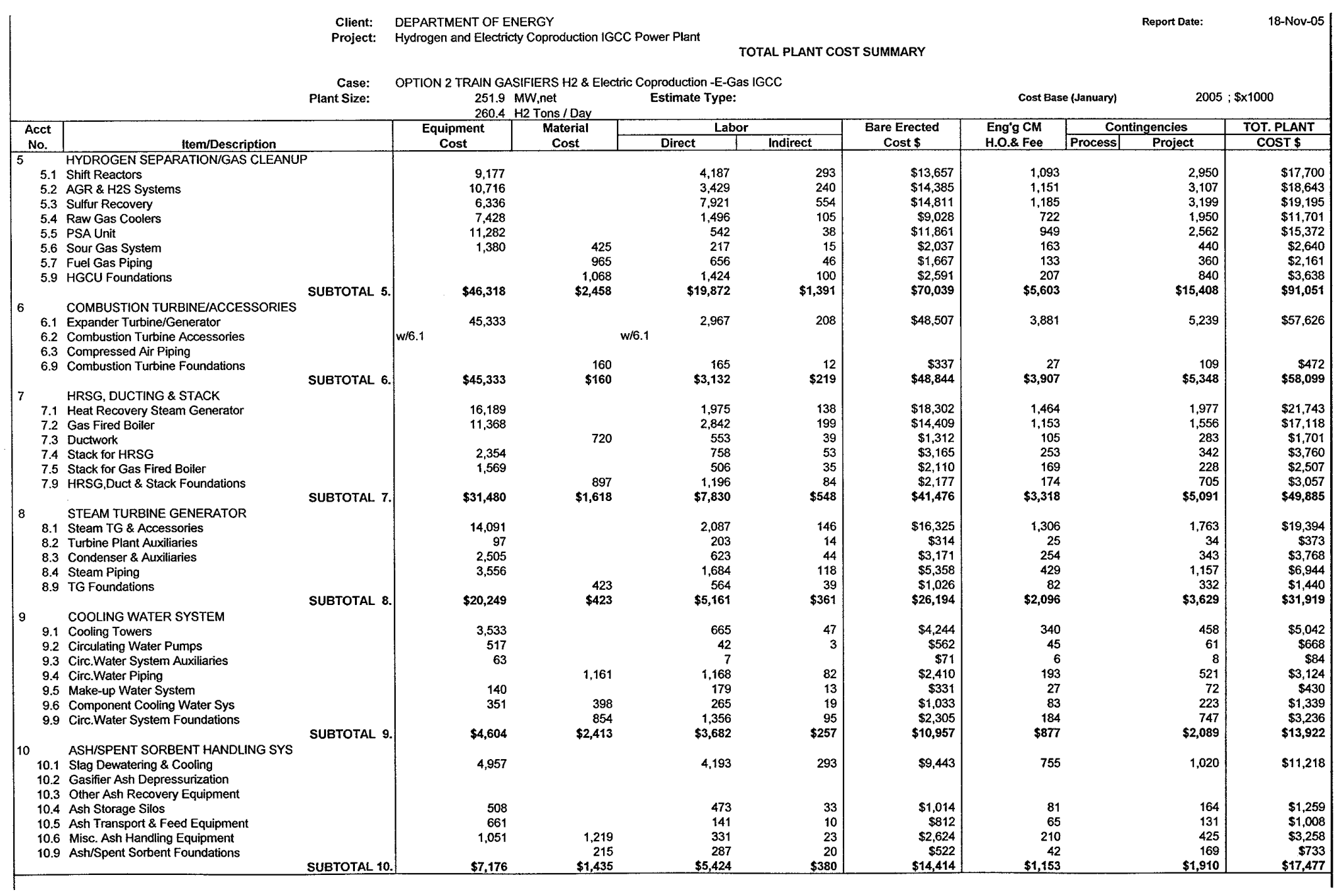




\begin{tabular}{|c|c|c|c|c|c|c|c|c|c|c|}
\hline & & $\begin{array}{l}\text { Client: } \\
\text { Project: }\end{array}$ & $\begin{array}{l}\text { DEPARTMENT OF E } \\
\text { Hydrogen and Electric }\end{array}$ & RGY & CC Power Plant & TAL PLANT $\cos$ & T SUMMARY & & Report Date: & 18-Nov-05 \\
\hline & & $\begin{array}{l}\text { Case: } \\
\text { Plant Size: }\end{array}$ & $\begin{array}{r}\text { OPTION } 2 \text { TRAIN GA } \\
251.9 \\
260.4 \\
\end{array}$ & $\begin{array}{l}\text { IERS H2 \& Elec } \\
\text { V,net } \\
\text { Tons / Day }\end{array}$ & $\begin{array}{l}\text { vic Coproduction -E-G } \\
\text { Estimate Type: }\end{array}$ & GCC & & Cost Base & e (January) & $\$ \times 1000$ \\
\hline $\begin{array}{l}\text { Acct } \\
\text { No. }\end{array}$ & Jtem/Description & & \begin{tabular}{|c|}
$\begin{array}{c}\text { Equipment } \\
\text { Cost }\end{array}$ \\
\end{tabular} & $\begin{array}{c}\text { Material } \\
\text { Cost }\end{array}$ & Direct & Indirect & $\begin{array}{l}\text { Bare Erected } \\
\text { Cost } \$\end{array}$ & $\begin{array}{l}\text { Eng'g CM } \\
\text { H.O.\& Fee }\end{array}$ & \begin{tabular}{|c|}
\multicolumn{2}{|c|}{ Contingencies } \\
Process|
\end{tabular} & $\frac{\text { TOT. PLANT }}{\text { COST \$ }}$ \\
\hline 11 & ACCESSORY EIECTRIC PIANT & & & & Direct & Inairect & & & & \\
\hline 111 & $\begin{array}{l}\text { ACCESSORY ELECTRIC PLANT } \\
\text { Genertor Eouipment }\end{array}$ & & $2559>>>>>>$ & & & & & & & \\
\hline 11.2 & Station Service Equipment & & 6,475 & & 453 & 32 & $\$ 6,959$ & 557 & 752 & $\begin{array}{l}\$ \$, 000 \\
\$ 8,268\end{array}$ \\
\hline 11.3 & Switchgear \& Motor Control & & 5,162 & 0 & 728 & 51 & $\$ 5,942$ & 475 & 963 & $\$ \$ \$, 379$ \\
\hline 11.4 & Conduit \& Cable Tray & & 0 & 2,950 & 8,286 & 580 & $\$ 11,816$ & 945 & 2,552 & $\$ 15,314$ \\
\hline 11.5 & Wire \& Cable & & 0 & 3,166 & 2,832 & 198 & $\$ 6,196$ & 496 & 1,338 & $\begin{array}{l}\$ 8,030 \\
\$ 8,030\end{array}$ \\
\hline 11.6 & Protective Equipment & & 0 & 226 & 676 & 47 & $\$ 949$ & 76 & 154 & $\$ \$ 1.179$ \\
\hline 11.7 & Standby Equipment & & 1,189 & & 22 & 2 & $\$ 1,212$ & 97 & 196 & $\$ \$ 1,506$ \\
\hline 11.8 & Main Power Transformers & & 6,017 & & 716 & 50 & $\$ 6,784$ & 543 & 1,099 & 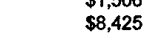 \\
\hline 11.9 & Electrical Foundations & & & 275 & & 48 & $\$ 1,003$ & & & $\$ 1,408$ \\
\hline & & SUBTOTAL 11. & $\$ 21,402$ & $\$ 6,617$ & $\$ 14,824$ & $\$ 1,038$ & $\$ 43,881$ & $\$ 3,510$ & $\$ 7,705$ & $\$ 55,096$ \\
\hline 12 & INSTRUMENTATION \& CONTROL & & & & & & & & & \\
\hline $\begin{array}{l}12.1 \\
12.2\end{array}$ & $\begin{array}{l}\text { IGCC Control Equipment } \\
\text { Combustion Turbine Control }\end{array}$ & & 1,333 & & & & & & & \\
\hline $\begin{array}{l}12.3 \\
12.4\end{array}$ & Steam Turbine Control & & 893 & & 462 & 32 & $\$ 1,388$ & 111 & 225 & $\$ 1,723$ \\
\hline $\begin{array}{l}72.4 \\
12.5\end{array}$ & $\begin{array}{l}\text { Signal Processing Equipment } \\
\text { Signer }\end{array}$ & & $w / 12.7$ & & $\mathrm{w} / 12.7$ & & & & & $+1,20$ \\
\hline 12.6 & Control Boards,Panels \& Racks & & 214 & & 107 & 8 & $\$ 329$ & 26 & 71 & $\$ 426$ \\
\hline 12.7 & Computer \& Accessories & & 6,837 & & 213 & 15 & $\$ 7,065$ & 565 & 763 & $\$ 8,394$ \\
\hline 12.8 & Instrument Wiring \& Tubing & & & 2,527 & 7,032 & 492 & $\$ 10,051$ & 804 & 2,171 & $\$ 13,026$ \\
\hline 12.9 & Other I \& C Equipment & & 1,574 & & & 42 & $\$ 2,208$ & 177 & 239 & \\
\hline & & SUBTOTAL 12. & $\$ 10,851$ & $\$ 2,527$ & $\$ 8,408$ & $\$ 589$ & $\$ 21,041$ & $\$ 1,683$ & $\$ 3,468$ & $\$ 26,193$ \\
\hline 13 & IMPROVEMENTS TO SITE & & & & & & & 58 & 235 & $\$ 1,018$ \\
\hline 13.1 & $\begin{array}{l}\text { Site Preparation } \\
\text { Sitit Imorovements }\end{array}$ & & & 1,201 & 1,327 & 93 & $\$ 2,620$ & 210 & 849 & $\$ \$ \$ 3,679$ \\
\hline $\begin{array}{l}13.2 \\
13.3\end{array}$ & $\begin{array}{l}\text { Site Improvements } \\
\text { Site Farilties }\end{array}$ & & & & 1,887 & 132 & $\$ 4,290$ & 343 & 1,390 & $\$ 6,023$ \\
\hline 13.3 & Site Facilities & SUBTOTAL 13. & $\$ 2,270$ & $\$ 1,237$ & $\$ 3,858$ & $\$ 270$ & $\$ 7,635$ & $\$ 611$ & $\$ 2,474$ & $\$ 10,720$ \\
\hline 14 & BUILDINGS \& STRUCTURES & & & & & & & 32 & 109 & $\$ 545$ \\
\hline 14.1 & $\begin{array}{l}\text { Combustion Turbine Area } \\
\text { Turbine Building }\end{array}$ & & & 2,064 & 2,933 & 205 & $\$ 5,203$ & 416 & 1,405 & $\$ 7,024$ \\
\hline 14.2 & Turbine $E$ & & & 496 & 359 & 25 & $\$ 880$ & 70 & 238 & $\$ 1,188$ \\
\hline $\begin{array}{l}14.3 \\
14.4\end{array}$ & Administration Building & & & 98 & 52 & 4 & $\$ 153$ & 12 & 41 & $\$ 206$ \\
\hline 14.4 & Circulation Water Pumphouse & & & 618 & 601 & 42 & $\$ 1,261$ & 101 & 340 & $\$ 1,702$ \\
\hline 14.5 & Water Treatment Buildings & & & 254 & 173 & 12 & $\$ 438$ & 35 & 118 & $\$ 592$ \\
\hline${ }_{14.6}^{14.6}-30-1$ & Machine & & & 409 & 263 & 18 & $\$ 690$ & 55 & 186 & $\$ 932$ \\
\hline 14.7 & $\begin{array}{l}\text { Warehouse } \\
\text { Gas Sired Boiler \& Other }\end{array}$ & & & 1.246 & 1,690 & 118 & $\$ 3,054$ & 244 & 825 & $\$ 4,123$ \\
\hline 14.8 & $\begin{array}{l}\text { Gas Fired Boiler \& Other Bulddings } \\
\text { Waste Treatito Builing \& Str. }\end{array}$ & & & 548 & 1,045 & 73 & $\$ 1,665$ & 133 & 450 & $\$ 2,248$ \\
\hline & Waste Treating Building \& Str. & SUBTOTAL 14. & & $\$ 5,983$ & $\$ 7,257$ & $\$ 508$ & $\$ 13,748$ & $\$ 1,100$ & $\$ 3,712$ & $\$ 18,559$ \\
\hline & & TOTAL COST & $\$ 331,244$ & $\$ 38,643$ & $\$ 144,386$ & $\$ \$ 10,107$ & $\$ 523,046$ & $\$ 41,844$ & $\$ 82,870$ & $\$ 647,760$ \\
\hline
\end{tabular}


$\underline{\text { Appendix C }}$

Foster Wheeler PCFB Gasifier Based Co-Production Plant

C-1 
C1. List of Major PCFB Co-Production Plant Equipment by Account

ACCOUNT 1A COAL RECEIVING AND HANDLING (serves entire plant)

\section{Equipment Description}

No.

$1 \quad$ Rotary Car Dumper and Receiving Hoppers

2 Feeder

3 Conveyor 1

4 As-Received Coal

Sampling System

5 Conveyor 2

6 Reclaim Hopper

7 Stacker-Reclaimer

$8 \quad$ Feeder

9 Conveyor 3

10 Crusher Tower

11 Coal Surge Bin w/Vent

Filter

12 Crusher

13 Crusher

14 As-Fired Coal Sampling System

15 Conveyor 4

16 Transfer Tower

17 Conveyor to CFB Boiler and Slurry Prep Coal

Silos

18
Type

N/A

Vibratory

$54 "$ belt

Two-stage

$54 "$ belt

N/A

Vibratory

48 " belt

N/A

Compartment

Granulator reduction

Impactor reduction

Swing hammer

48 " belt

N/A

Flat Belt

Vertical, cylindrical $\underline{\text { Design Condition } \quad \text { Qty. }}$

100 ton

1

450 tph $\quad 2$

900 tph 1

N/A

900 tph

100 ton

900 tph

200 tph

400 tph

400 tph

400 ton

400 tph

400 tph

N/A

2

400 tph

400 tph

250 tph

1000 ton

2 w/Vent Filter and Slide Gates 
ACCOUNT 1B LIMESTONE HANDLING and PREPARATION (serves entire plant)

$\underline{\text { Equipment Description }} \underline{\text { Type }} \underline{\text { Design Condition }} \underline{\text { Qty }}$

No.

$1 \quad$ Railcar Unloading

50 ton

2

Hoppers

$2 \quad$ Feeder

Vibratory

200 tph

2

3 Conveyor

30 inch flat belt

200 tph

1

\section{ACCOUNT 2 COAL-WATER SLURRY PREPARATION AND FEED} (serves FW PGM)

\begin{tabular}{|c|c|c|c|c|}
\hline$\frac{\text { Equipmen }}{\underline{\text { t No. }}}$ & $\underline{\text { Description }}$ & Type & $\underline{\text { Design Condition }}$ & Qty. \\
\hline 1 & Feeder & Weigh Belt & $120 \mathrm{tph}$ & 2@100\% \\
\hline 2 & Rod Mill & Rotary & $120 \mathrm{tph}$ & $2 @ 100 \%$ \\
\hline 3 & Slurry Water Pumps & Centrifugal & 210 gpm @ 500 ft & $2 @ 100 \%$ \\
\hline 4 & Slurry Water Storage Tank & Vertical & 12,500 gal & 1 \\
\hline 5 & Rod Mill Product Tank & Vertical & 33,000 gal & 2 \\
\hline 6 & Slurry Transfer pumps & $\begin{array}{l}\text { Centrifugal, elastomer } \\
\text { lined or hard metal }\end{array}$ & 820 gpm @ 100 ft & 4 \\
\hline 7 & $\begin{array}{l}\text { Slurry Storage Tank } \\
\text { with Agitator }\end{array}$ & Vertical & $132,000 \mathrm{gal}$ & 2 \\
\hline 8 & Coal-Slurry Feed Pumps & Progressing Cavity & 550 gpm @ 1,250ft & $2 @ 100 \%$ \\
\hline 9 & Slurry Heater & Shell and tube & $40 \times 10^{6} \mathrm{Btu} / \mathrm{h}$ & $2 @ 100 \%$ \\
\hline
\end{tabular}




\section{ACCOUNT 3 FEEDWATER AND MISCELLANEOUS BOP SYSTEMS}

\section{ACCOUNT 3A-1 CONDENSATE AND FEEDWATER SYSTEM-POWER TRAIN}

\begin{tabular}{|c|c|c|c|c|}
\hline$\frac{\text { Equipment }}{\text { No. }}$ & $\underline{\text { Description }}$ & $\underline{\text { Type }}$ & $\underline{\text { Design Condition }}$ & Qty \\
\hline 1 & $\begin{array}{l}\text { Condensate. Storage } \\
\text { Tank }\end{array}$ & $\begin{array}{l}\text { Vertical, cylindrical, } \\
\text { outdoor }\end{array}$ & 200,000 gal & 1 \\
\hline 2 & Condensate Pumps & Vertical canned & $\begin{array}{l}1,800 \text { gpm @ } 630 \mathrm{ft} \\
\text { TDH }\end{array}$ & $3 @ 50 \%$ \\
\hline 3 & LP Feedwater Heater & Shell and Tube & $\begin{array}{l}1,802,000 \mathrm{lb} / \mathrm{hr} ; 109 \mathrm{~F} \\
\text { to } 163 \mathrm{~F}\end{array}$ & 1 \\
\hline 4 & Deaerator & Horizontal spray type & $\begin{array}{l}1,802,228 \mathrm{lb} / \mathrm{h} \\
240^{\circ} \mathrm{F} \text { to } 336^{\circ} \mathrm{F}\end{array}$ & 1 \\
\hline 5 & HP Feed Pump & $\begin{array}{l}\text { Ring-segment type, } \\
\text { multi-staged, } \\
\text { centrifugal. }\end{array}$ & $\begin{array}{l}2000 \text { gpm @ } 8000 \mathrm{ft} \\
\text { TDH }\end{array}$ & $3 @ 50 \%$ \\
\hline 6 & $\begin{array}{l}\text { HP Feedwater Heater No. } \\
1\end{array}$ & Shell and Tube & $\begin{array}{l}949,000 \mathrm{lb} / \mathrm{hr}, 345 \mathrm{~F} \text { to } \\
372 \mathrm{~F}\end{array}$ & 1 \\
\hline 7 & $\begin{array}{l}\text { HP Feedwater Heater No. } \\
2\end{array}$ & Shell and Tube & $\begin{array}{l}949,000 \mathrm{lb} / \mathrm{hr}, 372 \mathrm{~F} \text { to } \\
410 \mathrm{~F}\end{array}$ & 1 \\
\hline 8 & $\begin{array}{l}\text { HP Feedwater Heater No. } \\
3\end{array}$ & Shell and Tube & $\begin{array}{l}949,000 \mathrm{lb} / \mathrm{hr}, 410 \mathrm{~F} \text { to } \\
487 \mathrm{~F}\end{array}$ & 1 \\
\hline
\end{tabular}

\section{ACCOUNT 3A-2 CONDENSATE AND FEEDWATER SYSTEM-H 2 TRAIN}

$\underline{\text { Equipment Description }}$

No.

$1 \quad$ LP Feed Pump
Type

Horizontal centrifugal single stage $\underline{\text { Design Condition }}$

Qty

650 gpm/1600 ft TDH 2@100\% 
ACCOUNT 3B MISCELLANEOUS EQUIPMENT (serves entire plant)

\begin{tabular}{|c|c|c|c|}
\hline$\frac{\text { Equipment }}{\text { No. }}$ & $\underline{\text { Description }}$ & Type & $\underline{\text { Design Condition }}$ \\
\hline 1 & Auxiliary Boiler & $\begin{array}{l}\text { Shop fabricated, water } \\
\text { tube }\end{array}$ & $\begin{array}{l}400 \mathrm{psig}, 650^{\circ} \mathrm{F} \\
70,000 \mathrm{lb} / \mathrm{h}\end{array}$ \\
\hline 2 & Service Air Compressors & $\begin{array}{l}\text { Reciprocating, single } \\
\text { stage, double acting, } \\
\text { horizontal }\end{array}$ & $100 \mathrm{psig}, 750 \mathrm{cfm}$ \\
\hline 3 & Inst. Air Dryers & Duplex, regenerative & $750 \mathrm{cfm}$ \\
\hline 4 & Service Water Pumps & $\begin{array}{l}\text { Horizontal centrifugal, } \\
\text { double suction }\end{array}$ & $200 \mathrm{ft}, 1,200 \mathrm{gpm}$ \\
\hline 5 & $\begin{array}{l}\text { Closed Cycle Cooling } \\
\text { Water Pumps }\end{array}$ & Horizontal, centrifugal & $70 \mathrm{ft}, 1,200 \mathrm{gpm}$ \\
\hline 6 & $\begin{array}{l}\text { Fire Service Booster } \\
\text { Pump }\end{array}$ & $\begin{array}{l}\text { Two-stage horizontal } \\
\text { centrifugal }\end{array}$ & $250 \mathrm{ft}, 1,200 \mathrm{gpm}$ \\
\hline 7 & Engine-Driven Fire Pump & $\begin{array}{l}\text { Vertical turbine, diesel } \\
\text { engine }\end{array}$ & $350 \mathrm{ft}, 1,000 \mathrm{gpm}$ \\
\hline 8 & Trash Rack/Rake & & \\
\hline 9 & Traveling Screen & & \\
\hline 10 & Screen Wash Pump & & \\
\hline 11 & Clarifier & & $3,500 \mathrm{gpm}$ \\
\hline 12 & Chemical Feed Skid & & \\
\hline 13 & Filter & & $3,500 \mathrm{gpm}$ \\
\hline 14 & Raw Water Pumps & SS, single suction & $60 \mathrm{ft}, 3,500 \mathrm{gpm}$ \\
\hline 15 & Filtered Water Pumps & SS, single suction & $160 \mathrm{ft}, 35100 \mathrm{gpm}$ \\
\hline 16 & Filtered Water Tank & Vertical, cylindrical & $1,000,000 \mathrm{gal}$ \\
\hline 17 & $\begin{array}{l}\text { Steam Cycle Makeup } \\
\text { Demineralizer }\end{array}$ & Reverse Osmosis Unit & $330 \mathrm{gpm}$ \\
\hline 18 & Chemical Feed Skid & & \\
\hline 19 & $\begin{array}{l}\text { Steam Cycle Makeup } \\
\text { Polisher }\end{array}$ & Electro Dialysis Unit & $330 \mathrm{gpm}$ \\
\hline 20 & $\begin{array}{l}\text { Sour Water Stripper } \\
\text { System }\end{array}$ & Vendor supplied & $\begin{array}{l}100,000 \mathrm{lb} / \mathrm{h} \text { sour } \\
\text { water }\end{array}$ \\
\hline 21 & $\begin{array}{l}\text { Liquid Waste Treatment } \\
\text { System }\end{array}$ & Vendor supplied & 300 gpm \\
\hline
\end{tabular}




\section{ACCOUNT 4 GASIFIER AND ACCESSORIES}

\section{ACCOUNT 4A GASIFICATION}

(1 gasifier train provided, serves for $\mathrm{H}_{2}$ and power trains,)

\begin{tabular}{|c|c|c|c|}
\hline$\frac{\text { Equipment }}{\underline{\text { No. }}}$ & $\underline{\text { Description }}$ & Type & $\underline{\text { Design Condition }}$ \\
\hline 1 & $\begin{array}{l}\text { Gasifier, including char } \\
\text { processing system }\end{array}$ & $\begin{array}{l}\text { Pressurized fluidized } \\
\text { bed/syngas cooler }\end{array}$ & $\begin{array}{l}2790 \text { std (dry-coal } \\
\text { basis)@ } 439 \text { psia @ } \\
\text { outlet }\end{array}$ \\
\hline 2 & $\begin{array}{l}\text { Raw Gas Cooler/Fire tube } \\
\text { Boiler }\end{array}$ & Fire tube boiler & $\begin{array}{l}700 \mathrm{psig} / 503^{\circ} \mathrm{F} \\
284 \mathrm{MMBtu} / \mathrm{h}\end{array}$ \\
\hline 3 & Cyclone & $\begin{array}{l}\text { Carbon steel, abrasion } \\
\text { resistant liner }\end{array}$ & $434 \mathrm{psig}, 650 \mathrm{~F}$ \\
\hline 4 & $\begin{array}{l}\text { Medium-Temperature } \\
\text { Candle Filter, with Back } \\
\text { Pulse system }\end{array}$ & $\begin{array}{l}\text { Sintered stainless steel } \\
\text { filter, carbon steel vessel }\end{array}$ & $428 \mathrm{psia}, 650^{\circ} \mathrm{F}$ \\
\hline 6 & $\begin{array}{l}\text { Syngas Candle Filter } \\
\text { Backpulse Compressor }\end{array}$ & $\begin{array}{l}\text { Positive Displacement } \\
\text { with Accumulator, skid } \\
\text { mounted }\end{array}$ & $2,000 \mathrm{lb} / \mathrm{hr} . \mathrm{PR}=1.35: 1$ \\
\hline 5 & Flare Stack & $\begin{array}{l}\text { Self-supporting, carbon } \\
\text { steel, stainless steel top, } \\
\text { pilot ignition }\end{array}$ & $\begin{array}{l}471,000 \mathrm{lb} / \mathrm{h}, \text { medium- } \\
\text { Btu gas }\end{array}$ \\
\hline
\end{tabular}

\section{ACCOUNT 4B AIR SEPARATION PLANT}

(serves entire plant, 1 trains at $100 \%$ capacity)

\begin{tabular}{|c|c|c|c|}
\hline$\frac{\text { Equipment }}{\underline{\text { No. }}}$ & $\underline{\text { Description }}$ & $\underline{\text { Type }}$ & $\underline{\text { Design Condition }}$ \\
\hline 1 & Air Compressor & Centrifugal, multi-stage & $\begin{array}{l}\text { 142,000 scfm, } 70 \text { psia } \\
\text { discharge pressure }\end{array}$ \\
\hline 2 & Cold Box & Vendor supplied & 1,730 ton/day $\mathrm{O}_{2}$ \\
\hline 3 & Oxygen Compressor & Centrifugal, multi-stage & $\begin{array}{l}32,000 \mathrm{scfm} \text { at } 455 \mathrm{psig} \\
\text { discharge press. }\end{array}$ \\
\hline 4 & $\begin{array}{l}\text { Liquid Oxygen Storage } \\
\text { Tank }\end{array}$ & Vertical & $60^{\prime}$ dia. $x$ 80' vert \\
\hline
\end{tabular}




\section{ACCOUNT 5 SYNGAS SHIFT AND CLEANUP}

\section{ACCOUNT 5A WATER-GAS SHIFT AND RAW GAS COOLING}

\section{ACCOUNT 5A-1 H2 PRODUCTION TRAIN}

\begin{tabular}{|c|c|c|c|}
\hline$\frac{\text { Equipment }}{\text { No. }}$ & Description & Type & Design Condition \\
\hline 1 & $\begin{array}{l}\text { High Temperature Shift } \\
\text { Reactor No. } 1\end{array}$ & Fixed bed & $\begin{array}{l}587,000 \mathrm{lb} / \mathrm{hr} ; 427 \mathrm{psia} \\
\text { inlet, } 815 \mathrm{~F} \text { outlet; } 230 \mathrm{cu} \\
\mathrm{ft} \text { catalyst }\end{array}$ \\
\hline 2 & $\begin{array}{l}\text { High Temperature Shift } \\
\text { Reactor No. } 2\end{array}$ & Fixed bed & $\begin{array}{l}587,000 \mathrm{lb} / \mathrm{hr} ; 412 \mathrm{psia} \\
\text { inlet, } 612 \mathrm{~F} \text { outlet, } 230 \mathrm{cu} \\
\mathrm{ft} \text { catalyst }\end{array}$ \\
\hline 3 & $\begin{array}{l}\text { Low Temperature Shift } \\
\text { Reactor }\end{array}$ & Fixed bed & $\begin{array}{l}587,000 \mathrm{lb} / \mathrm{hr} ; 400 \mathrm{psia} \\
\text { inlet, } 419 \mathrm{~F} \text { outlet, } 115 \mathrm{cu} \\
\mathrm{ft} \text { catalyst }\end{array}$ \\
\hline 4 & $\begin{array}{l}\text { HT Shift } 1 \text { Raw Gas } \\
\text { Cooler }\end{array}$ & Shell and tube & $\begin{array}{l}74 \times 10^{6} \mathrm{Btu} / \mathrm{h} \text { with BFW } \\
\text { @ } 3050 \mathrm{psig} \text { inlet, } 498^{\circ} \mathrm{F} \\
\text { outlet }\end{array}$ \\
\hline 5 & $\begin{array}{l}\text { HT Shift } 2 \text { Raw Gas } \\
\text { Cooler }\end{array}$ & Shell and tube & $\begin{array}{l}65 \times 10^{6} \mathrm{Btu} / \mathrm{h} \text { with } \\
\mathrm{BFW} @ 3070 \text { psig inlet, } \\
417^{\circ} \mathrm{F} \text { outlet }\end{array}$ \\
\hline 6 & $\begin{array}{l}\text { LT Shift } 1 \text { Raw Gas } \\
\text { Cooler }\end{array}$ & Shell and tube & $\begin{array}{l}139 \times 10^{6} \mathrm{Btu} / \mathrm{h} \text { with } \\
\text { condensate@ } 135 \mathrm{psig} \\
\text { inlet, } 240^{\circ} \mathrm{F} \text { outlet }\end{array}$ \\
\hline 7 & PSA Raw Gas Cooler & $\begin{array}{l}\text { Shell and tube with } \\
\text { condensate drain }\end{array}$ & $\begin{array}{l}52 \times 10^{6} \mathrm{Btu} / \mathrm{h} \text {, with } \\
\text { Cooling Water @ } 100 \\
\text { psig inlet, } 139 \mathrm{~F} \text { outlet }\end{array}$ \\
\hline 8 & $\begin{array}{l}\text { Raw Gas Knock Out } \\
\text { Drum }\end{array}$ & $\begin{array}{l}\text { Vertical with mist } \\
\text { eliminator }\end{array}$ & 400 psia, $130^{\circ} \mathrm{F}$ \\
\hline 10 & Sour Gas Stripper & Vertical Column & $\begin{array}{l}99,000 \mathrm{lb} / \mathrm{hr} \text { sour/gray } \\
\text { water flow rate }\end{array}$ \\
\hline 11 & Stripper Reflux Heater & Shell and tube & \\
\hline 12 & $\begin{array}{l}\text { Sour Water Collection } \\
\text { Tank }\end{array}$ & & \\
\hline
\end{tabular}

Qty 
ACCOUNT 5A-2 POWER TRAIN-not Applicable

ACCOUNT 5B ACID GAS REMOVAL AND GAS CONDITIONING

ACCOUNT 5B-1 $\mathrm{H}_{2}$ PRODUCTION TRAIN

Equipment Description Type

No.

1 PSA Unit $\quad$ Fixed bed

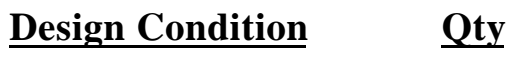

487,686 lb/hr syngas

for 101 MMscfd $\mathrm{H}_{2} @$

370 psia

\section{ACCOUNT 5B-2 POWER TRAIN \\ Not Applicable \\ ACCOUNT 5C SULFUR RECOVERY and TAIL GAS RECYCLE \\ Not Applicable \\ ACCOUNT 6 COMBUSTION TURBINE/and ACCESSORIES \\ Not Applicable}

ACCOUNT 7 FIRED BOILER AND STACK-

\section{Equipment Description}

No.

$1 \quad$ Fired Circulating Fluid

Bed Boiler, including coal and limestone silos, feeders, ash coolers, fans, tubular air heater, SNCR storage and injection, dry scrubber, baghouse

2

Stack
Type

Drum Type, Balanced Draft with natural circulation

Design Condition Qty Drums

Carbon steel plate, type, 409 stainless steel liner
Superheat steam:

1,790,000 lb/hr at 2527 psig/1005F

Reheat steam:

$1,848,000 \mathrm{lb} / \mathrm{hr}$ at 570

psig/1005F

1

$213 \mathrm{ft}$ high x $20 \mathrm{ft}$ dia. $\quad 1$ 
ACCOUNT 8 STEAM TURBINE GENERATOR AND AUXILIARIES

\begin{tabular}{|c|c|c|c|}
\hline$\frac{\text { Equipment }}{\underline{\text { No. }}}$ & $\underline{\text { Description }}$ & $\underline{\text { Type }}$ & $\frac{\text { Design Condition }}{\text { (per each) }}$ \\
\hline 1 & $\begin{array}{l}310 \text { MW Steam } \\
\text { Turbine Generator }\end{array}$ & $\begin{array}{l}\text { Reheat, TC2F40, Down } \\
\text { Exhaust, Hydrogen Cooled } \\
\text { Generator }\end{array}$ & $\begin{array}{l}2400 \mathrm{psig} / 1000 \mathrm{~F} / \\
1000^{\circ} \mathrm{F}\end{array}$ \\
\hline 2 & $\begin{array}{l}\text { Bearing Lube Oil } \\
\text { Coolers }\end{array}$ & Plate and frame & \\
\hline 3 & $\begin{array}{l}\text { Bearing Lube Oil } \\
\text { Conditioner }\end{array}$ & Pressure filter closed loop & \\
\hline 4 & Control System & Digital electro-hydraulic & \\
\hline 5 & Generator Coolers & Plate and frame & \\
\hline 6 & Surface Condenser & $\begin{array}{l}\text { Single pass, divided } \\
\text { waterbox }\end{array}$ & $\begin{array}{l}1400 \mathrm{MM} \mathrm{Btu} / \mathrm{h}, 2.0 \\
\text { in } \mathrm{Hga}\end{array}$ \\
\hline 7 & $\begin{array}{l}\text { Condenser Vacuum } \\
\text { Pumps }\end{array}$ & Rotary, water sealed & $\begin{array}{l}\text { 2500/25 scfm } \\
\text { (hogging/holding) }\end{array}$ \\
\hline
\end{tabular}

\section{ACCOUNT 9 COOLING WATER SYSTEM}

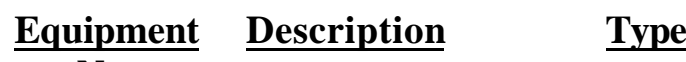

No.

1 Circ. Water Pumps Vertical wet pit

2 Cooling Tower Mech. draft, multi-cell, 19F

App./20F Range/53F WB

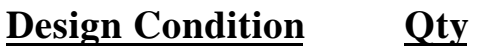 \\ (per each) \\ 81,000 gpm @ $60 \mathrm{ft}$ 3@ 50\% $\mathrm{TDH}$}

$162,000 \mathrm{gpm}$

1 


\section{ACCOUNT 10 ASH/SPENT SORBENT RECOVERY AND HANDLING}

\begin{tabular}{|c|c|c|c|c|}
\hline$\frac{\text { Equipment }}{\text { No. }}$ & $\underline{\text { Description }}$ & $\underline{\text { Type }}$ & $\underline{\text { Design Condition }}$ & Qty \\
\hline 1 & $\begin{array}{l}\text { Fly Ash Transport } \\
\text { Blowers, including inlet } \\
\text { and outlet silencers }\end{array}$ & $\begin{array}{l}\text { Positive Displacement } \\
\text { (oil injected screw or } \\
\text { Roots type) }\end{array}$ & $\begin{array}{l}50 \text { tph design } / 37 \text { tph } \\
\text { normal operating, }\end{array}$ & $2 @ 100 \%$ \\
\hline \multirow[t]{2}{*}{2} & Fly Ash Silo & $\begin{array}{l}\text { Slip-form concrete, flat } \\
\text { bottom }\end{array}$ & $\begin{array}{l}2700 \text { tons ( } 72 \mathrm{hrs} \text { at } \\
\text { normal operating rate) }\end{array}$ & 1 \\
\hline & $\begin{array}{l}\text { Fly Ash Fluidizing } \\
\text { Blower }\end{array}$ & Positive Displacement & $50 \mathrm{hp}$ & $2 @ 100 \%$ \\
\hline 3 & $\begin{array}{l}\text { Fly Ash Silo Filter and } \\
\text { Vent Fan }\end{array}$ & $\begin{array}{l}\text { Bag Filter/Centrifugal } \\
\text { Fan }\end{array}$ & & 1 \\
\hline 4 & Fly Ash Conditioner & Pug Mill & $120 \mathrm{tph}$ & 1 \\
\hline 5 & Fly Ash Unloading Chute & Retractable & $120 \mathrm{tph}$ & 1 \\
\hline 6 & $\begin{array}{l}\text { Bed Ash Drag Chain } \\
\text { Conveyor }\end{array}$ & Drag Chain & $\begin{array}{l}20 \text { tph design, } 13 \text { tph } \\
\text { normal operating }\end{array}$ & $2 @ 100 \%$ \\
\hline 7 & Bed Ash Bucket Elevator & & $20 \mathrm{tph}$ & $2 @ 100 \%$ \\
\hline 8 & Bed Ash Silo & $\begin{array}{l}\text { Slip-form concrete, } \\
\text { fabricated steel conical } \\
\text { bottom }\end{array}$ & $\begin{array}{l}1000 \text { tons ( } 72 \mathrm{hrs} \text { at } \\
\text { normal operating rate) }\end{array}$ & 1 \\
\hline 9 & $\begin{array}{l}\text { Bed Ash Silo Filter and } \\
\text { Vent Fan }\end{array}$ & $\begin{array}{l}\text { Bag Filter/Centrifugal } \\
\text { Fan }\end{array}$ & & 1 \\
\hline 10 & Bed Ash Conditioner & Pug Mill & $40 \mathrm{tph}$ & 1 \\
\hline 11 & Bed ash Unloading Chute & Retractable & $40 \mathrm{tph}$ & 1 \\
\hline
\end{tabular}




\section{C2. Total Plant Cost Estimate}

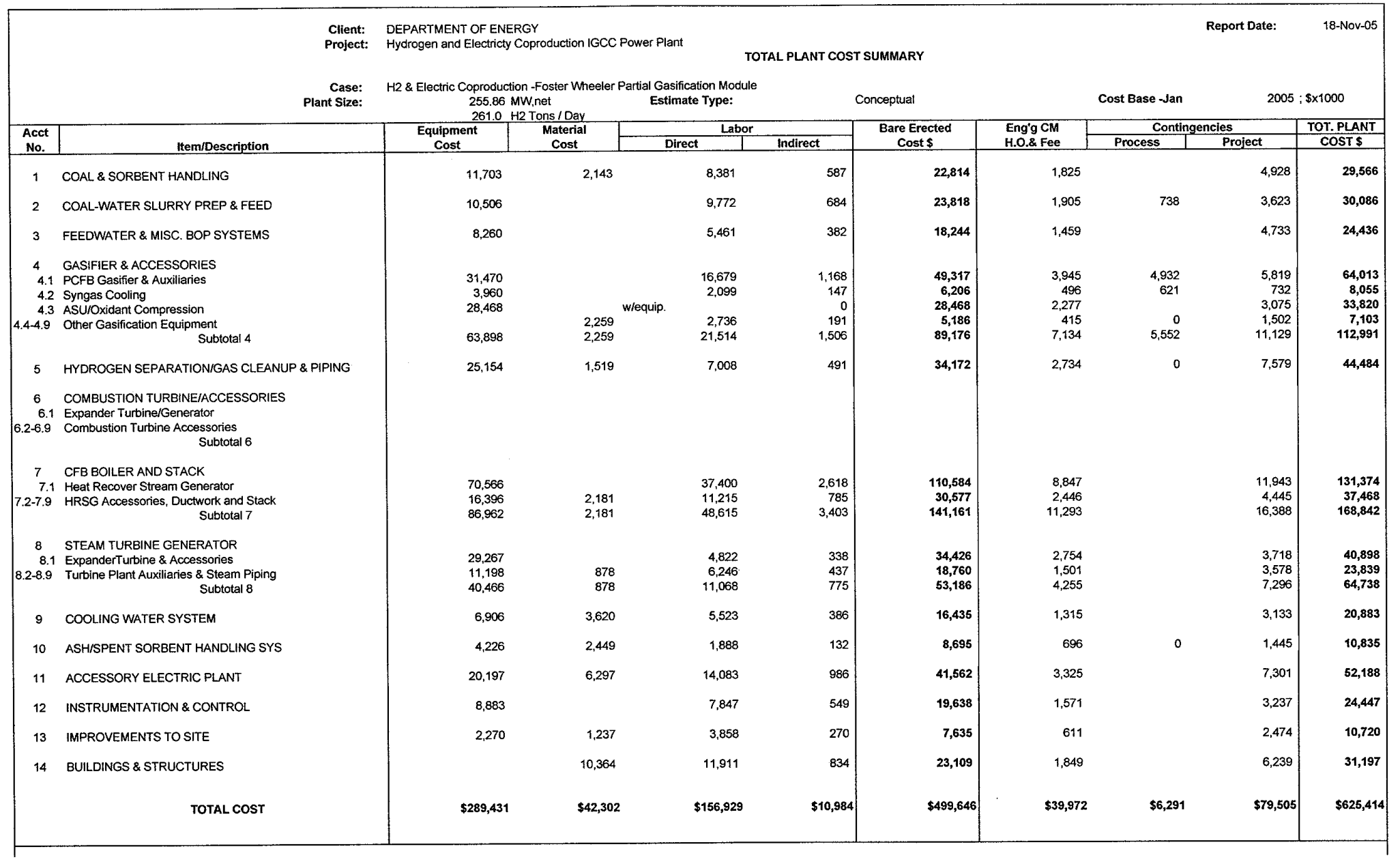




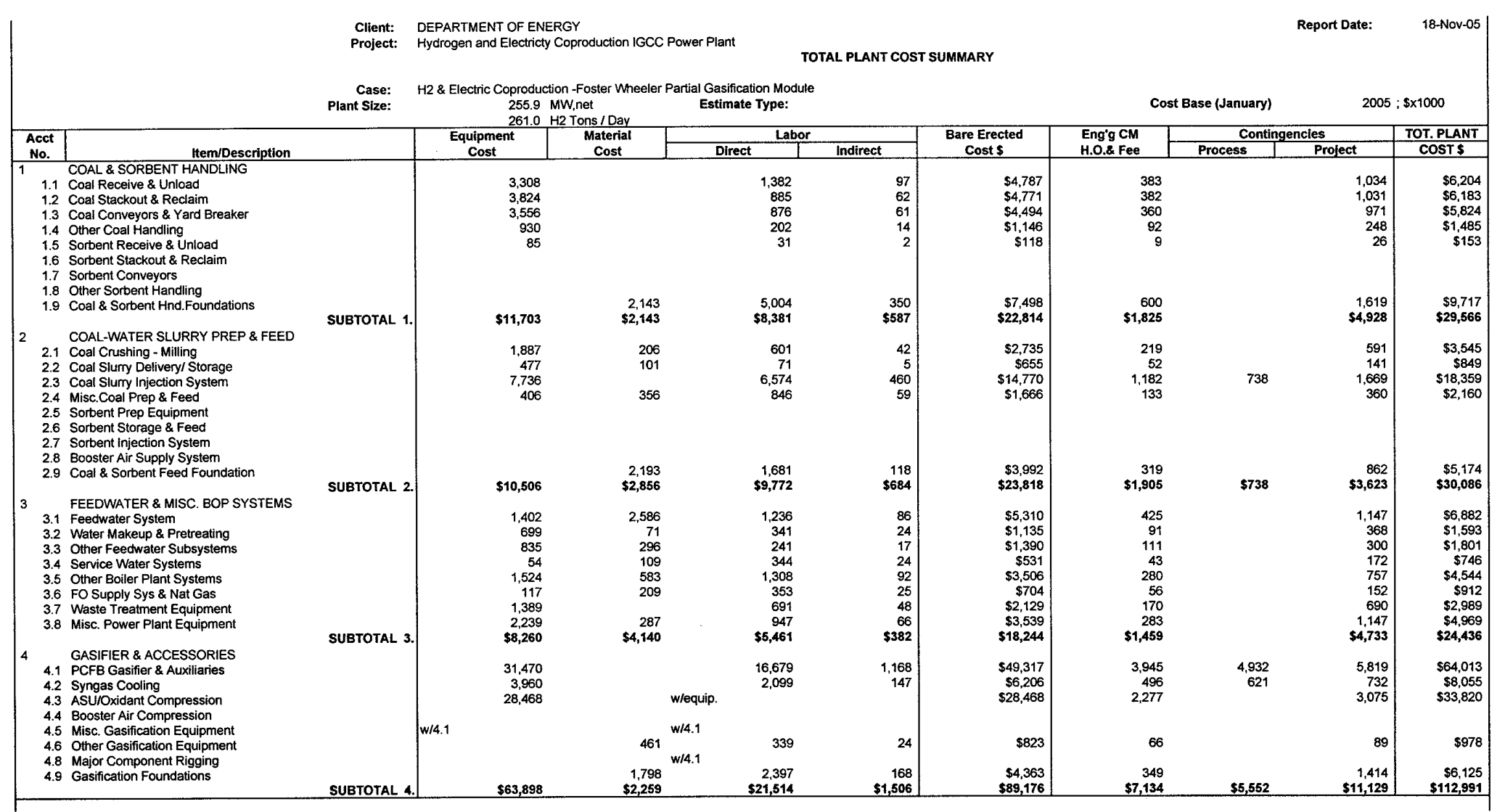




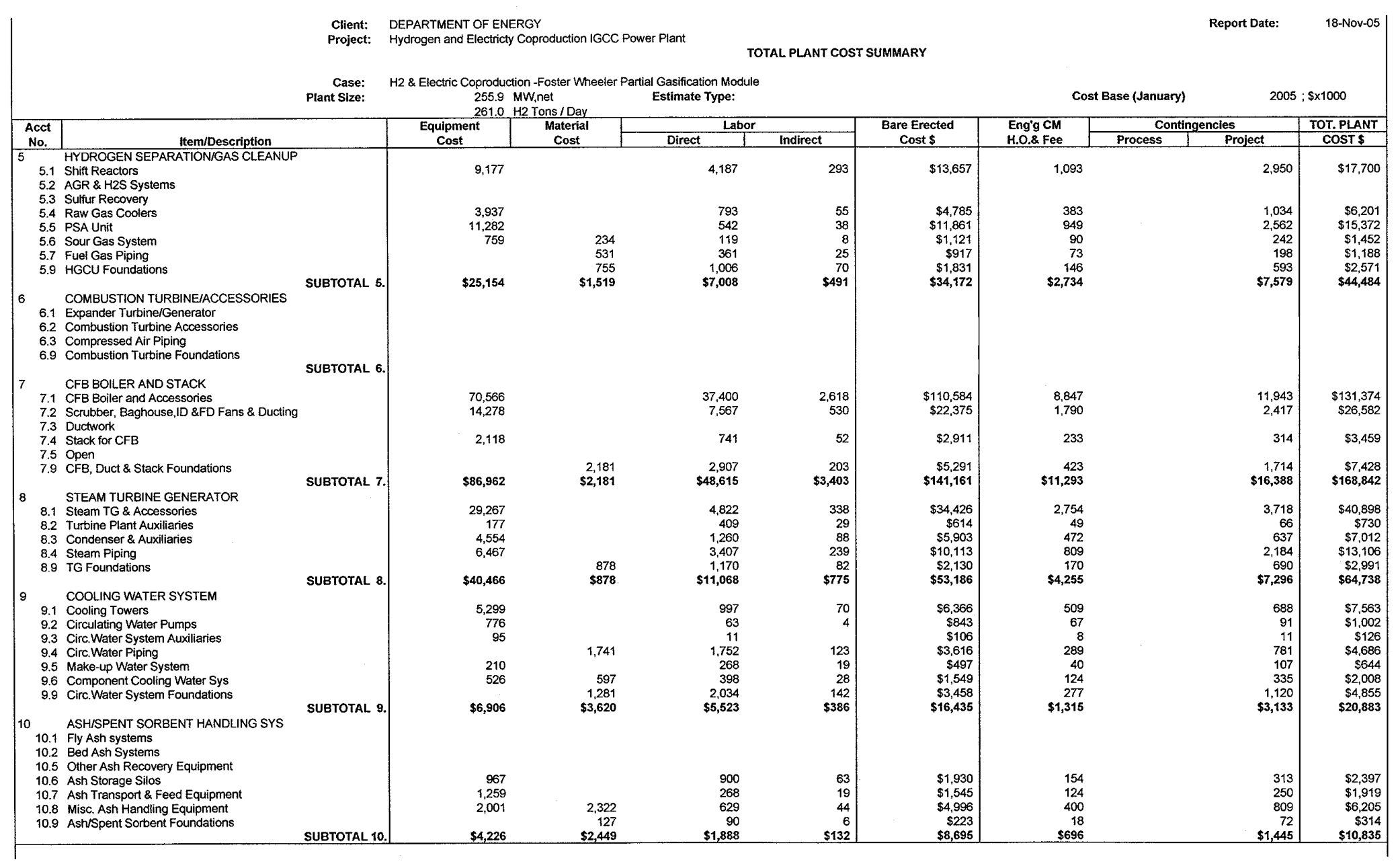




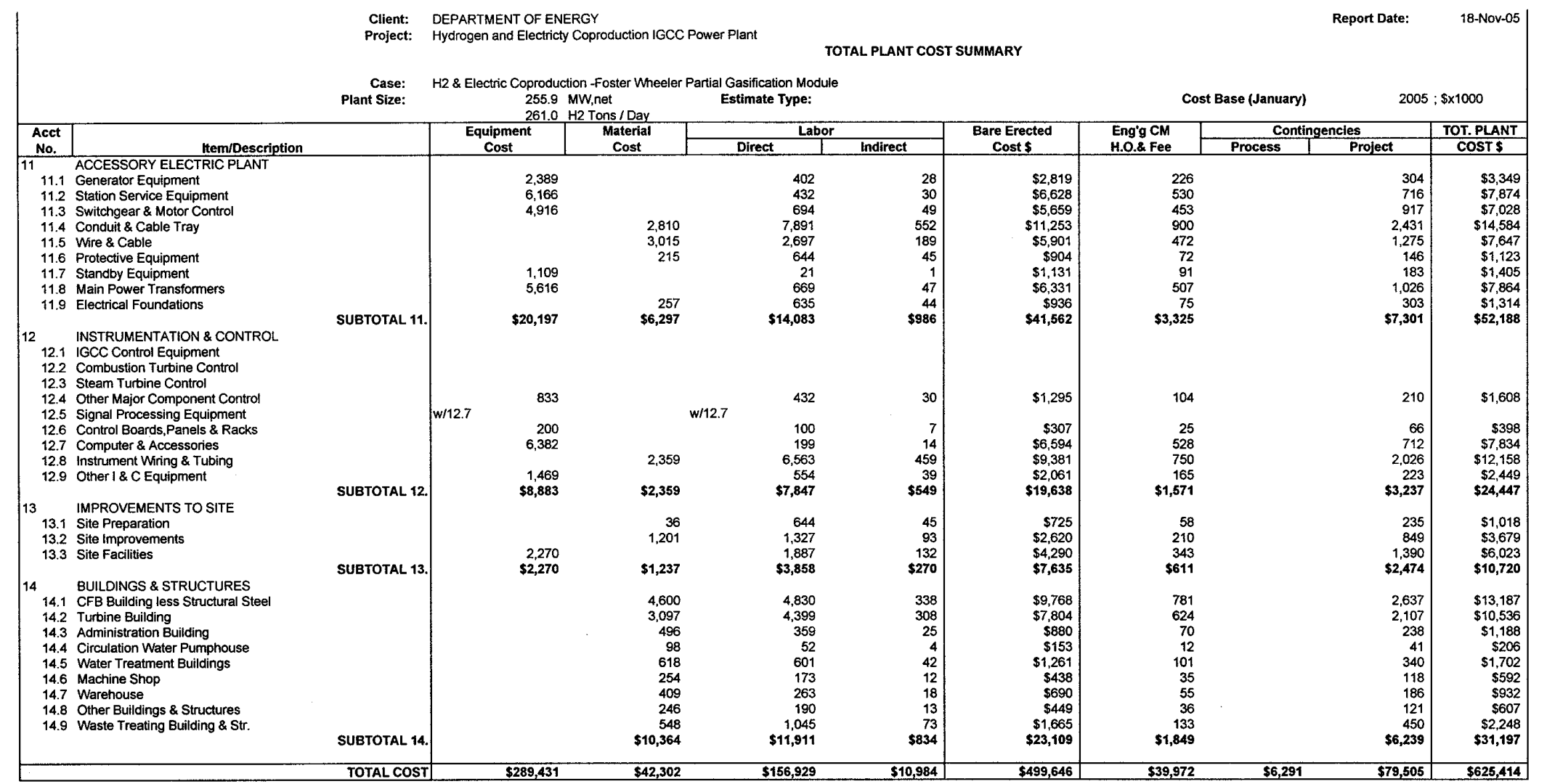

